THAÍSSA TAMARINDO DA ROCHA WEISHAUPT PRONI

PROTEÇÃO CONSTITUCIONAL À MATERNIDADE NO BRASIL: UM CASO DE EXPANSÃO DA GARANTIA LEGAL

DISSERTAÇÃO DE MESTRADO

ORIENTADOR: PROF. DR. ANTONIO RODRIGUES DE FREITAS JUNIOR

FACULDADE DE DIREITO - UNIVERSIDADE DE SÃO PAULO São Paulo

2012 
Thaíssa Tamarindo da Rocha Weishaupt Proni

\section{PROTEÇÃO CONSTITUCIONAL À MATERNIDADE NO BRASIL: UM CASO DE EXPANSÃO DA GARANTIA LEGAL}

Dissertação apresentada ao Programa de PósGraduação da Faculdade de Direito da Universidade de São Paulo, como requisito parcial para obtenção do título de Mestre em Direito do Trabalho.

Orientação: Prof. Dr. Antonio Rodrigues de Freitas Junior

Faculdade de Direito - USP

São Paulo

2012 
Thaíssa Tamarindo da Rocha Weishaupt Proni

\section{PROTEÇÃO CONSTITUCIONAL À MATERNIDADE NO BRASIL: UM CASO DE EXPANSÃO DA GARANTIA LEGAL}

MEMBROS DA BANCA EXAMINADORA:

PROF. DR. ANTONIO RODRIGUES DE FREITAS JUNIOR UNIVERSIDADE DE SÃO PAULO

PROF. DR.

UNIVERSIDADE DE SÃO PAULO

PROFA. DRA. 


\section{AGRADECIMENTOS}

Agradeço ao meu orientador, Antonio Rodrigues de Freitas Junior, por ser um Mestre no aspecto mais autêntico do termo. Por me guiar de forma segura no desenvolvimento deste estudo. Pela oportunidade de trabalhar junto a ele no Programa de Aperfeiçoamento e Estágio. Pela confiança, pela sinceridade, pelo incentivo.

Agradeço ao meu querido marido Marcelo, pela companhia, incentivo e apoio durante os anos de Mestrado, sem o qual sei que seria muito mais penoso assumir esta responsabilidade.

Agradeço aos meus pais, pelo apoio incondicional. Ao meu pai, pelas horas à minha espera no Largo São Francisco, meu companheiro de viagem, que tantas vezes abdicou do próprio trabalho para me acompanhar em minhas aulas e atividades.

A todos os colegas que me acompanharam neste período tão importante de minha vida.

A todos os professores que fazem parte deste programa de pós-graduação.

A todos os funcionários da Faculdade de Direito da USP, pelos serviços a mim prestados com tanta dedicação durante este período. 


\section{RESUMO}

Esta dissertação é dedicada à análise da proteção à maternidade no Brasil e à expansão legal desta garantia social nos últimos anos. Em tese, este direito constitucional permite uma condição melhor da mulher no mercado de trabalho e uma maior proteção à criança recém-nascida, além de possibilitar a conciliação entre as responsabilidades do trabalho e da família, adequando-se às exigências da sociedade moderna. Neste sentido, parte-se da hipótese de que a expansão desta garantia legal propicia o aperfeiçoamento da eficácia da proteção social.

O objetivo do presente estudo é examinar como a garantia legal de proteção à maternidade evoluiu no cenário normativo nacional e como o avanço obtido em 1988 assegurou a ampliação da eficácia da proteção referida. Através de um balanço jurídicohistórico, a dissertação comprova que, a despeito dos discursos à época da Constituinte, a ampliação do instituto não resultou na queda do emprego feminino, nem mesmo em prejuízo para a atividade empresarial.

Mais especificamente, procura-se demonstrar que a expansão da garantia legal pode constituir ferramenta para o aperfeiçoamento da eficácia da proteção (ao contrário do que os conservadores afirmaram e ainda afirmam de modo ideológico e contrafactual). Para isso, a dissertação revê a trajetória do instituto da proteção à maternidade, em perspectiva de balanço, analisando seus avanços no tempo. O que se evita afirmar (e aí se impõe o limite desta argumentação) é que toda expansão da garantia legal necessariamente promova o aperfeiçoamento da eficácia da proteção; também, por outro lado, que somente pela expansão da garantia legal seja possível aperfeiçoar a eficácia da proteção.

Procedimentos metodológicos: 1) revisão bibliográfica dos textos constitucionais e das obras que comentam o assunto para a organização do quadro teórico; 2) realização de pesquisa documental para examinar o debate ocorrido na época da Constituinte e da aprovação da atual Lei 11.770/2008; 3) produção de tabelas sobre a evolução do emprego feminino a partir de dados do MTE, assim como quadros comparativos da licençamaternidade com base em publicações do PNUD e da OIT.

O tema é extremamente relevante e capaz de provocar uma reflexão acerca do papel decisivo da inserção da proteção social nas Constituições, o que garantiu sua eficácia ao longo do tempo. Além disso, é relevante para criticar a falta de consistência de discursos contrários à ampliação de direitos trabalhistas (em particular, da classe empregadora), bem como indicar a necessidade de aprimoramento da legislação do trabalho acerca da proteção à maternidade, em especial pelos direitos de conciliação entre trabalho e família.

Em suma, a dissertação propõe um estudo inédito sobre o tema e apresenta um enfoque alinhado com as tendências internacionais neste campo. Além disso, aponta, por meio da avaliação dos processos jurídico-históricos, diferentes caminhos para aprimorar a eficácia da proteção à maternidade por meio do instrumental normativo.

Palavras-chave: proteção à maternidade; Lei 11.770/2008; direito do trabalho; trabalho da mulher. 


\begin{abstract}
This dissertation is addressed to the analysis of maternity protection in Brazil and the expansion of social insurance law in recent years. In theory, this constitutional right allows a better condition of women in the labor market and greater protection to the newborn child, besides facilitating the conciliation between work responsibilities and family, adjusting to the demands of modern society.

In this sense, it is normally assumed that the expansion gives legal guarantee of improving the effectiveness of social protection.

The aim of this study is to examine how the legal guarantee of maternity protection in the regulatory landscape has evolved and how the national progress made in 1988 ensured the increased efficacy of such protection. Through a balance of legal and historical vision, the dissertation shows that, despite the speeches at the time of the new Constitution's Congress, not the expansion of the Institute resulted in the decline of female employment, even in injury to the business activity.

More specifically, it seeks to demonstrate that the expansion of the legal guarantees can be a tool for enhancing the effectiveness of protection (contrary to what conservatives have said and still say so ideological and counterfactual). For this, the paper reviews the history of the institute of protection of motherhood, analyzing their progress over time. The study avoids stating that any expansion of the legal guarantee necessarily promotes the improvement of the effectiveness of protection. And on the other hand, one cannot think that only the expansion of the legal guarantee to be able to improve the effectiveness of protection.

Methodological procedures: 1) literature review of constitutional texts and works that comment on the matter to the organization of the of the theoretical framework; 2) conducting archival research to examine the debate occurred at the time of the Constitution's Congress and the approval of the current law (Lei 11.770/2008); 3) production of tables on the evolution of female employment data from the Labor Ministry, as well as comparative tables of maternity leave based on publications of UNDP and ILO.

The theme is extremely relevant and able to cause a reflection on the crucial role of the insertion of social protection in the Federal Constitution, which guaranteed its effectiveness over time. Moreover, it is important to criticize the lack of consistency of the arguments against the extension of labor rights (in particular, by employers) and indicate the need for improvement of labor legislation on the protection of motherhood, especially for the rights of reconciling work and family.

In short, the paper proposes a new study about the topic and presents an approach in line with international trends in this field. In addition, he noted, by evaluating the legal and historical processes, different ways to enhance the effectiveness of maternity protection through legal instruments.
\end{abstract}

Keywords: maternity protection; Brazilian legislation; labor law; women's work. 


\section{SUMÁRIO}

Introdução

1. Proteção constitucional à maternidade

1.1. Mulher e trabalho

1.2. A proteção à maternidade no mundo contemporâneo

1.3. Trajetória da proteção constitucional à maternidade no Brasil

2. O debate acerca da extensão da licença-maternidade na Assembléia Constituinte (1987-1988) e seus desdobramentos

2.1. Discursos sobre a ampliação da proteção à maternidade

2.2. Negação do mito: o crescimento do emprego formal feminino

3. A posição da OIT sobre pontos relevantes da proteção à maternidade

3.1. As convenções internacionais sobre a proteção à maternidade

3.2. Posição atual da OIT sobre a proteção à maternidade

4.1. Licença médica, flexibilidade na jornada, estabilidade no emprego 
5.1. Proteção à mãe adotante e à mãe social

5.2. Proteção à maternidade, direitos de conciliação entre trabalho e família e a nova divisão sexual do trabalho

6. Avanços legislativos recentes da proteção à maternidade

6.1. Argumentos a favor e contrários aos projetos de lei

6.2. A Lei 11.770/2008 e seus desdobramentos

6.3. Repercussão geral da matéria previdenciária no STF 


\title{
INTRODUÇÃO
}

\begin{abstract}
"Ao lado de bens e valores sociais que inegavelmente integram o repertório objetivo dos direitos humanos, como por exemplo, os que se projetam no eixo das liberdades, na qualificação jurídica da privacidade, na erradicação de mecanismos sociais constitutivos de desigualdades adjetas de gênero, de orientação sexual, de fé, etc., o trabalho permanece figurando entre aqueles fatores sem os quais é impossivel traçar contornos confiáveis para a compreensão do ser humano contemporâneo."
\end{abstract}

O papel da mulher nas sociedades ocidentais, de um modo geral, tem sido revolucionado nas últimas décadas, em especial à medida que vai sendo reinventado seu modo de ser no mundo do trabalho e na esfera da família. No Brasil, desde que os poetas Mário Lago e Ataulfo Alves compuseram “Ai, que saudades da Amélia”, em 1942, contando o estereótipo da dona de casa conformada com sua condição de esposa e mãe, muita coisa mudou e cada vez mais mulheres têm assumido vários papéis ao mesmo tempo e mostrado que é possível conciliar a vida familiar com a vida profissional, inclusive galgando postos de direção e comando em grandes empresas e atuando em cargos públicos.

Não obstante toda a carga cultural que pesa sobre os ombros das mulheres de serem as exclusivas cuidadoras das crianças, idosos e de pessoas portadoras de necessidades especiais, inclusive a de serem mães e amamentadoras, as novas gerações de mulheres têm procurado demonstrar a sua expertise em equilibrar as várias funções e ocupar espaços que foram conquistados por meio de lutas históricas, motivadas pelo desejo e aspiração de liberdade e igualdade dentro de sociedades predominantemente patriarcais.

${ }^{1}$ FREITAS JR., Antonio Rodrigues de (org.). Direito do trabalho e direitos humanos, São Paulo: BH Editora, 2006, Apresentação, p. 6. 
Exemplos são abundantes. Uma das maiores empresas de bens de consumo, a multinacional Procter \& Gamble atualmente tem uma mulher brasileira na direção de negócios na América do Norte. Esta administradora ocupa hoje a lista das mulheres mais poderosas em duas das revistas de negócios mais famosas do mundo (Fortune e Forbes). Segundo declarações dela, costuma trabalhar até 12 horas por dia na empresa e consegue arrumar tempo para preparar o almoço da filha, fazer exercícios e sair com os amigos ${ }^{2}$.

Outro de muitos exemplos é o da equipe de engenheiras da Dupont, multinacional da área química e de agrotecnologia. Ocupando uma área que há alguns anos era composta essencialmente pela força de trabalho masculina, este grupo de mulheres compõe uma geração à qual a divisão de papéis masculinos e femininos já não faz nenhum sentido. Agrônomas, engenheiras de alimentos, geneticistas, engenheiras químicas e outras profissionais da Dupont, lideram pesquisas e equipes, além de cuidarem de suas famílias, como uma segunda jornada. Segundo informações da própria empresa, hoje a Dupont emprega 656 mulheres na filial no Brasil, representando $36 \%$ do quadro geral de funcionários, sendo que mais da metade está em cargos de liderança.

Não obstante estes avanços revolucionários, as conquistas no campo do trabalho implicaram e implicam no acúmulo de jornadas: fora e dentro do lar (conforme acima).

Afora o acúmulo de jornadas, há ainda outro desafio para as mulheres trabalhadoras. É que no mercado de trabalho, por vezes, a mulher ainda sofre algumas resistências por ser a reprodutora, aquela que se afastará das atividades para gozar a licença-maternidade. Embora a família seja protegida pela Constituição Federal e por muitas vozes da sociedade nacional e internacional, parece que sua perpetuação não é prioritária, quando isso reflete em remanejamento de prioridades capitalistas.

A reprodução humana interessa à sociedade como um todo, pois educar e cuidar das crianças é um investimento nas gerações futuras, significa a evolução do homem. Apesar disso, o fato da responsabilidade de bem criar as crianças recair quase que totalmente sobre as mulheres tem feito com que elas sejam qualificadas (ou desqualificadas) como uma força inferior de trabalho, pelas limitações que isso lhes impõe.

Todavia, como cumpridora de uma função social primordial, a reprodução deveria estar totalmente integrada à vida pública e laboral e não ser vista como uma parte particular do mundo feminino e das aspirações ligadas à luta de gênero.

\footnotetext{
${ }^{2}$ SALOMONE, Roberto. Perfil: Melanie Healey, Você S/A, ed. 13, Especial Mulheres 2, junho de
} 2011. 
A proteção constitucional à maternidade foi elevada ao patamar dos direitos sociais $^{3}$ pelas Constituições e Tratados Internacionais na onda construtiva do Estado Social e do constitucionalismo moderno, cujos precursores foram a República de Weimar e o México (1919 e 1917), permitindo, tais movimentos, o estabelecimento da igualdade real entre os indivíduos por meio da positivação de direitos sociais mínimos, a garantia denominada "mínimo existencial", conceito cuja abrangência foi-se alargando com o tempo $^{5}$.

No Brasil, tal movimento histórico acabou por influenciar a elaboração da Constituição de 1934, e posteriormente nortear os primeiros momentos da construção do Estado de bem-estar nacional, quando então os direitos sociais foram positivados e elevados ao patamar constitucional, movimento este que culminou na Constituição Cidadã de 1988, que revelou o caráter evolutivo da questão no ordenamento pátrio.

Este estudo pretende, então, realizar uma discussão a respeito da eficácia da proteção constitucional à maternidade no Brasil e ampliação de suas garantias e, também, investigar, ainda que de forma sumária, as limitações de outras normas correlatas quanto ao vislumbre dos direitos de conciliação entre trabalho e família, frente à nova divisão sexual do trabalho.

${ }^{3}$ Para o mestre alemão Robert Alexy, os direitos sociais são considerados fundamentais, podendo ser também denominados direitos a prestação em sentido estrito. Para o ilustre jurista, direitos a prestação em sentido estrito são "direitos do indivíduo em face do Estado, a algo que este indivíduo, se dispusesse de meios financeiros suficientes e se houvesse uma oferta suficiente no mercado, poderia também obter de particulares. Quando se fala em direitos fundamentais sociais, como por exemplo, direitos à assistência à saúde, ao trabalho, à moradia e à educação, quer-se primariamente fazer menção a direitos a prestação em sentido estrito." ALEXY, Robert. Teoria dos direitos fundamentais, 2. ed. São Paulo: Malheiros Editores, 2011 [1986], cap. 9, p. 499.

4 Conceito de "mínimo existencial" em Alexy: um direito às condições mínimas de existência humana digna que não pode ser objeto de intervenção do Estado e que ainda exige prestações estatais positivas, como, por exemplo, o direito da mãe à proteção e à assistência na Constituição alemã, artigo $6^{\circ}$, $\S 4^{\circ}$. ALEXY, Robert. Teoria dos direitos fundamentais, 2011, cap. 7.

${ }^{5}$ Qual a extensão do mínimo social? Segundo John Rawls: "O bom senso pode contentar-se em dizer que o nível correto depende da riqueza média do país e que, outros fatores permanecendo constantes, o mínimo deve ser mais alto que essa média aumenta. Ou também poderia se dizer que o nível adequado é determinado por expectativas costumeiras. Mas essas proposições são insatisfatórias. A primeira delas não é suficientemente precisa, já que não explica como o mínimo depende da riqueza média e ignora outros aspectos relevantes tais como a distribuição; ao passo que a segunda não oferece critério algum para que se diga quando as próprias expectativas costumeiras são razoáveis. Depois de aceito o princípio de diferença, contudo, deve-se estabelecer o mínimo no ponto em que, levando-se em conta os salários, maximize as expectativas do grupo menos favorecido. Ajustando-se o montante de transferências (por exemplo, o montante dos benefícios monetários suplementares), é possível aumentar ou diminuir as perspectivas dos mais desafortunados, o seu índice de bens primários (medido pelos salários mais transferências), de modo a chegar ao resultado desejado." RAWLS, John. Uma teoria da justiça. São Paulo: Martins Fontes, 2008 [1971], cap. 5, p. 355. 
Com este escopo definido, convém esclarecer que o estudo está dividido em seis capítulos, além da introdução e da conclusão. Primeiramente, é feita uma breve referência à maneira como a proteção à maternidade é tratada nas Constituições, indicando a diversidade de situações nacionais encontradas atualmente, e se realiza uma análise da trajetória da proteção à maternidade no Brasil.

O segundo capítulo apresenta uma análise dos discursos em torno da elaboração da atual Constituição Federal no que se refere à necessidade e à viabilidade econômica da ampliação dos direitos sociais, com foco no tema da proteção à maternidade. Em acréscimo, examina a evolução do emprego feminino no período posterior à aprovação da Constituição de 1988.

No terceiro capítulo, é apontada a evolução do debate no TST e a argumentação da OIT sobre pontos relevantes da proteção à maternidade. A posição dos Tribunais Superiores, por meio da edição de súmulas, tendeu a esclarecer pontos da legislação, reafirmando a proteção à maternidade e ao trabalho da mulher, colocando em evidência alguns aspectos tratados em normas coletivas do trabalho. Por sua vez, as convenções da OIT e os estudos publicados pela instituição permitem entender o esforço de estabelecer um patamar mínimo de proteção à maternidade, ainda que as diferenças nacionais sejam muito claras, em especial no que se refere à duração e financiamento da licençamaternidade.

O capítulo quarto coloca em consideração outras garantias legais, tais como a licença médica, flexibilidade na jornada, estabilidade no emprego e proteção no pós-parto. Também procura discutir o papel desempenhado pela negociação coletiva neste campo.

No quinto capítulo, a prioridade é indicar outros aspectos relacionados com o tema em questão, com ênfase em duas frentes de ampliação dos direitos: a proteção legal à mãe adotante e à mãe social; e a limitação legal aos direitos de conciliação entre trabalho e família, num contexto de mudanças na divisão sexual do trabalho.

O sexto capítulo se destina à análise dos avanços legislativos infraconstitucionais recentes. Começa apresentando os argumentos a favor e contrários à ampliação da licençamaternidade. Em seguida, enfatiza os avanços propiciados pela Lei 11.770/2008. Além disso, comenta a repercussão geral da matéria previdenciária no STF. Espera-se, assim, contribuir para o debate jurídico, realizando uma análise crítica da eficácia da proteção constitucional à maternidade, em sintonia com as ondas protetivas na evolução histórica nacional. 
Ao que tudo indica, neste caso específico de proteção, a ampliação da proteção à maternidade pode constituir ferramenta para o aperfeiçoamento da eficácia da proteção, ao contrário do que os atores conservadores afirmaram e ainda afirmam de modo ideológico e contrafactual. No entanto, não se pode afirmar aqui, que toda expansão da garantia legal necessariamente promova o aperfeiçoamento da eficácia da proteção, nem, por outro lado, que somente pela expansão da garantia legal seja possível aperfeiçoar a eficácia da proteção. Exatamente aí se estabelecem os limites deste trabalho.

Dessa forma, pretende-se contribuir para os debates recentes a respeito da ampliação do destes direitos sociais, bem como contribuir com parâmetros jurídicos que possam propiciar iniciativas para a criação de uma legislação pátria que considere a proteção à maternidade à luz da conciliação entre trabalho e família, não apenas por se tratar de uma necessidade das mulheres, mas da sociedade em geral. 


\title{
CAPÍTULO 1
}

\section{PROTEÇÃO CONSTITUCIONAL À MATERNIDADE}

\author{
"É pelo trabalho que a mulher vem diminuindo a distância que a separava do homem; \\ somente o trabalho poderá garantir-lhe uma independência concreta."
} Simone de Beauvoir

A evolução do direito positivo em matéria constitucional foi fundamental para que a mulher conquistasse um espaço digno no mundo do trabalho. A proteção conferida por estes comandos legais permitiu, em última análise, uma maior participação da mulher no mercado de trabalho e a elevação contínua destes índices na atualidade, em regra (e formalmente), com os mesmos direitos dos homens.

Há, sim, incongruências e alguma utopia neste tipo de afirmação (quando categórica), porque os percalços foram e são diversos; foi com a luta de gênero e com embate argumentativo dos atores sociais que a história pôde registrar avanços no tema “trabalho da mulher". E o diálogo dos atores continua ocorrendo, a cada cogitação de nova configuração legislativa sobre a matéria.

Por isso mesmo, cumpre perguntar, então: nesta época, homens e mulheres realmente são iguais em direito e obrigações? Em adição: o alargamento da proteção à maternidade restringe ou apóia esta igualdade? E isto pode afetar a participação da mulher no mercado de trabalho, em quantidade e qualidade, comparando-se com a massa de trabalho masculina?

Pode-se entender que seria impossível a promoção da dignidade e igualdade da mulher no trabalho sem a proteção à maternidade e à criança, pois como bem indicou o 
jurista Homero Batista Mateus da Silva, "proteção à maternidade e ao recém-nascido são formas diretas de proteção ao trabalho da mulher (grifo meu)"

Parece razoável concluir que a condição primordial para que a mulher pudesse se inserir no mundo do trabalho é que houvesse também legislação especial para seu tratamento. Não é a premissa da justiça, que para concretizá-la, é necessário tratar os desiguais de forma desigual ${ }^{7}$ ? Se assim não fosse, não se justificaria a legislação que distingue a carga máxima de carregamento de peso para homens e mulheres, segundo artigo 198 (homens) e artigo 390 (mulheres) da CLT. Não é verdade que a massa muscular e óssea feminina, em regra e considerando-se o perfil físico da mulher média, é mais frágil?

E não é verdade que somente a mulher, até hoje, é biologicamente capaz de gerar uma criança? Segundo a jurista Alice Monteiro de Barros, a gestação inclui muito mais que carregar a criança no ventre. Para ela, "trata-se de um processo psicológico complexo, de intensa atividade emocional, que testa tanto as reservas físicas e psíquicas quanto a sua aptidão para criar uma nova vida",

Igualmente, não é sobre a mãe adotiva que recai a maior parte da responsabilidade de cuidar do filho, quando este chega ao lar adotivo, sendo ele bebê ou criança maior? A amamentação, mesmo que pela mamadeira, não fica, na maior parte do tempo, a encargo da mãe? A mãe adotiva, igualmente, passa por processo psicológico complexo durante o processo de adoção. Certamente, suas reservas físicas e psíquicas são postas à prova.

Nesta toada, não da fragilidade feminina, mas da própria diferença entre os sexos imposta pela biologia e pela cultura (papel social de mulher), a necessidade de uma legislação especial se impõe. Em particular, no caso da maternidade.

Veremos, neste capítulo, a evolução desta legislação específica e as diferenças de concessão da licença-maternidade no direito estrangeiro.

6 SILVA, Homero Batista Mateus da. Curso de direito do trabalho aplicado. Rio de Janeiro: Elsevier, 2009, vol. 3, p. 153.

${ }^{7}$ Desde o pensamento de Platão e Aristóteles, o conceito de justiça caminha de braços dados com o conceito de igualdade. É útil relembrar que, tanto pela filosofia do direito (REALE, Miguel. Filosofia do direito, 1999[1953]) quanto pela política (BOBBIO, Norberto. Igualdade e liberdade, 1997), em se tratando de igualdade, há dois comandos que precisam ser respeitados: a) a lei não pode fazer distinção entre as pessoas que ela considera iguais; b) a lei deve fazer distinções a fim de igualar a desigualdade existente no meio social, ou, a lei deve fazer distinção entre as pessoas que considera desiguais. Exemplos: proteção aos idosos, estatuto da criança e do adolescente e as leis especiais ao consumidor.

${ }^{8}$ BARROS, Alice Monteiro de. A mulher e o direito do trabalho. São Paulo: LTr, 1995, p. 39. 


\subsection{Mulher e trabalho}

As conquistas das mulheres no campo do trabalho foram obtidas sempre graças à sua capacidade de luta, de mobilização, de pressão. Olhar um pouco esta história e reter alguns momentos marcantes de afirmação do poder feminino pode ajudar a entender o contexto mais abrangente no qual ocorrem as disputas por direitos constitucionais. De acordo com Paula Cantelli, durante a transição da fase de exclusão para a de proteção, embora submissas no trabalho e no lar, havia uma parcela de mulheres que já se envolviam nos movimentos populares. Embora submetidas às mais variadas discriminações, não foram poucas as mulheres que lutaram em movimentos sociais inspirados, por exemplo, pela Revolução Francesa de 1789 (momento marcante em que desempenharam papel decisivo, lutando em favor da liberdade contra a opressão, ajudando a derrubar a monarquia em defesa de melhores condições de vida) ${ }^{9}$.

Ao longo do século XIX, algumas mulheres exerceram papel de extrema relevância no surgimento das leis relativas ao trabalho. Foi diante das denúncias de exploração feminina (e infantil) que o Estado sensibilizou-se e interveio, ainda que de forma incipiente, nas condições de trabalho que afetavam os empregados. Tanto que as primeiras leis trabalhistas referem-se ao trabalho da mulher e do menor, conforme se sabe.

$\mathrm{Na}$ Inglaterra, centro industrial e maior potência mundial, foi publicado em $1842 \mathrm{o}$ "Coal Mining Act", lei que proibia o trabalho da mulher em subterrâneos; em 1844, o "Factory Act", que reduzia a jornada de trabalho para doze horas e vedava às mulheres o trabalho noturno; em 1878, o "Factory and Workshop Act", que fixava a carga semanal feminina em 55 horas e meia na indústria têxtil e em 60 horas nas outras fábricas, excluindo o domingo ${ }^{10}$.

Estas legislações provocaram efeitos ambíguos: por um lado, disciplinaram e restringiram a super-exploração do trabalho feminino; por outro, provocaram atitudes discriminatórias contra as trabalhadoras nos ramos industriais. Muitos dos direitos conquistados em face da diferença de sexo, embora necessários, acabaram gerando, ainda

\footnotetext{
9 “(...) uma enorme multidão enfurecida de mulheres esfomeadas avançou sobre Versalhes no ato que pôs fim à monarquia (...). E foram as mulheres que tomaram a iniciativa dos atos mais violentos em defesa do pão para os seus filhos" (MURARO, Rose M., A mulher no terceiro milênio. Rio de Janeiro: Rosa dos Tempos, 2000, apud CANTELLI, Paula Oliveira. O trabalho feminino no divã: dominação e discriminação. São Paulo: LTr, 2007, p. 77.
}

${ }^{10}$ BARROS, Alice Monteiro de. A mulher e o direito do trabalho. São Paulo: LTr, 1995, p. 30. 
que indiretamente, maior discriminação contra o trabalho da mulher. No último quarto do século XIX, à medida que aumentavam as restrições em relação ao trabalho da mulher, a procura por mão-de-obra feminina diminuía consideravelmente, verificando-se, assim, certo movimento de retração da mulher para o lar.

Essa tendência manteve-se por muito tempo. No início do século $\mathrm{XX}$, com o avanço da industrialização e o crescimento dos serviços urbanos, houve uma nova onda de inserção das mulheres no mercado de trabalho. Contudo, elas continuavam sendo vistas como mão-de-obra barata, dócil, que podia ser sobre-explorada facilmente. Em 1910, quando ocorreu o primeiro congresso internacional de mulheres, em Copenhagen, entre as principais reivindicações estavam o direito de voto e melhores condições de trabalho. Neste congresso foi proposta a criação do "dia das mulheres"11.

A reversão daquelas atitudes contrárias à contratação de mulheres foi possível, em especial, por causa das necessidades trazidas pela Primeira Guerra Mundial, que exigiu o trabalho feminino nas fábricas e em vários outros setores de atividade. Gradualmente, foi sendo retirado o caráter de tutela que era imposto sobre o trabalho da mulher. Posteriormente, com a Segunda Guerra Mundial, houve um grande avanço em termos do papel que as mulheres passaram a desempenhar no mercado de trabalho dos países industrializados.

De qualquer forma, a desigualdade entre homens e mulheres no trabalho não foi eliminada. A organização do trabalho característica do fordismo - com trabalho repetitivo e padronizado, com ambientes de trabalho mais limpos e seguros - possibilitou às mulheres voltarem às fábricas, porém não é certo que no mesmo patamar dos homens: elas agora tinham empregos menos vulneráveis, porém, ainda ocupando as funções pior remuneradas. E mesmo com a introdução do toyotismo - com fábricas enxutas e linhas de produção mais eficientes - a situação não se alterou muito. Segundo Laís Abramo e Marianela Armijo, os processos de modernização tecnológica e organizacional não proporcionaram às mulheres, de um modo geral, acesso a novas profissões ou a postos de trabalho melhor remunerados ou com maior responsabilidade, muito pelo contrário. $\mathrm{Na}$

${ }^{11}$ Cf. UNITED NATIONS. International Women's Day, 1997. O Dia Internacional da Mulher, 8 de março, só foi definido pela ONU em 1975. Uma explicação sobre a origem do movimento sugere que no congresso internacional de 1910 foi marcada a primeira comemoração do dia da mulher para 19 de março de 1911. Poucos dias depois, houve um trágico incêndio, ocorrido em 25 de março de 2011 numa fábrica têxtil em New York, no qual morreram 146 trabalhadores, a grande maioria mulheres, vítimas de más condições de trabalho e descaso dos patrões. Esse episódio ficou marcado no imaginário coletivo. Posteriormente, houve uma greve de operárias russas contra a fome e a guerra, em 8 de março de 1917, que serviu como estopim para a revolução contra o czar. 
América Latina, a partir do momento em que a qualificação passou a ser imprescindível para a manutenção do emprego, as mulheres foram, novamente, colocadas em posição secundária no mercado de trabalho ${ }^{12}$.

Sob a visão do sociólogo italiano, Antonio Negri, estes movimentos de atração e repulsa de trabalhadoras mulheres no mercado de trabalho qualificado e produtivo refletem, ao fim das contas, uma inserção definitiva da mulher no mundo do trabalho. Assim, atualmente estaríamos vivendo a era da feminilização do trabalho. Aponta:

"E do ponto de vista das mulheres? Parece-me que neste ponto se assiste a uma paradoxal 'heteronomia das finalidades'. Explico-me. O feminismo havia exaltado a mulher como um gênero separado ou, de outro modo, como capaz de se equiparar aos homens; em torno destas finalidades havia desdobrado a sua revolução. Agora, à diferença das previsões, a feminilidade está se tornando o elemento decisivo naquele campo que era reservado ao homem: o trabalho produtivo. Longe de se separarem, as qualidades femininas do trabalho atingem todo o território produtivo; longe de alcançarem uma equiparação, as mulheres se tornam hegemônicas na biopolítica pós-moderna. E logo tomarão consciência disso."13

Esta é a trajetória do trabalho da mulher, relatada em breves palavras e sob o olhar que interessa a esta investigação. Porém, não se pode ignorar que falar em proteção à maternidade é também abordar, numa perspectiva maior, a condição do trabalho feminino. Por isso, é preciso ir um pouco além. É preciso considerar outro approach, pertinente e interessante, que merece ser aprofundado: o trabalho sob a condição feminina. Condição assim empregada não mediante a acepção que lhe empresta a teoria geral dos atos jurídicos, mas enquanto posição social e institucional contingente aos que se encontram sob o impacto da discriminação à mulher.

De acordo com Antonio Rodrigues Freitas Junior ${ }^{14}$, para abordar o problema da discriminação da mulher, deve-se considerar que, com a evolução das legislações relativas à igualdade de gênero e participação da mulher no mercado de trabalho, a questão da isonomia neste tema revela duas nuances: a igualdade formal e a substantiva, no sentido

12 ABRAMO, Laís; ARMIJO, Marianela. Cambio tecnológico y el trabajo de las mujeres. Revista Estudos Feministas, vol. 5, n. 1, 1997.

${ }^{13}$ NEGRI, Antonio. A feminização do trabalho, Folha de São Paulo, São Paulo, 14.jun.1998, Seção Autores, p. 1.3.

${ }^{14}$ Cf. FREITAS JR, Antonio Rodrigues de. O trabalho feminino no Brasil. Revista Jurídica do trabalho, ano 1, n. 3, out./dez. 1988. 
de, respectivamente, se referir à materialidade conceitual do direito e depois à "dimensão criadora", substantiva deste mesmo direito.

Como corolário, entendemos que a regulamentação, por si, não constitui passaporte de entrada da mulher ao mercado de trabalho, sob as mesmas condições dos homens trabalhadores. As condições permanecem assimétricas e a equalização destas características é um trabalho constante e, inclusive, atual.

Não se pode entender, todavia, que, em todos os casos, a regulamentação propicia ou propiciou o único e melhor caminho para encaminhar o problema. Inclusive, neste trabalho, a investigação se aprofunda em relação ao bem jurídico proteção à maternidade e à evolução da regulamentação deste mesmo bem. Ao final, o que se pretende demonstrar é que a seqüência de fatos sociais e transformações legislativas, a contento, propiciaram uma inegável contribuição à questão do trabalho sob a condição feminina.

É importante argumentar, ainda, nesta toada, que o trabalho sob a condição feminina sofreu (na onda das mesmas discussões pré e pós-constitucionais de 1988), uma crítica que procurou justificar a assimetria citada acima, fundada na alegação da menor qualificação da mulher em relação aos homens, o que atualmente se encontra quase que totalmente superado.

Não menos importante notar que toda a evolução social relativa ao tema contrariou uma visão da própria comunidade jurídica (magistrados, procuradores, operadores do direito e legisladores), de que o problema do trabalho da mulher era um problema de "minoria" (algum tratamento semelhante às minorias étnicas), e que seria tratável, por vezes, pela própria mulher, por meio de suas "novas atitudes", resultantes do perfil da mulher moderna (diga-se, preparada e treinada).

Ainda segundo Freitas $^{15}$, comumente, figuraram explicações que tendiam a devolver à mulher as causas da desigualdade. Assim, vêm os argumentos no sentido de que é no mercado, mediante procedimentos de capacitação e habilitação adequados, que a mulher (re)aprenderia seu papel de cidadã e de trabalhadora competitiva. Desde que assegurados os contornos da isonomia e restabelecida a equivalência de direito entre os sexos, suprimindo em vez de ampliando - o estatuto protetor especial à mulher, num mecanismo de plena competição com a mão-de-obra masculina.

${ }^{15}$ FREITAS JR, Antonio Rodrigues de. O trabalho feminino no Brasil. Revista Jurídica do trabalho, ano 1, n. 3 , out./dez. 1988 . 
Os fatos econômicos e sociais comprovaram, finalmente, que tais afirmações são frágeis e simplistas. A inserção das mulheres em cargos altamente qualificados, no ramo privado e público, por si, desbanca boa parte desta argumentação.

Mas, ao final, o que se deseja não é a desconstrução de teorias, mas a efetividade de direitos que são as aspirações de um povo, elevadas ao patamar constitucional de um estado democrático festejado e bem-vindo. Continuar construindo soluções que envolvam o Estado, a iniciativa privada e o movimento sindical (por meio da negociação coletiva) parece ser o caminho mais adequado para a realização da dignidade e igualdade de gênero no trabalho. Continuar propiciando segurança às mulheres que conciliam a vida familiar com a profissional é nada menos que promover esta igualdade de direitos e de oportunidades $^{16}$.

\subsection{A proteção à maternidade no mundo contemporâneo}

A inserção dos direitos sociais nos textos constitucionais inaugura uma nova fase no constitucionalismo moderno, o das constituições escritas, com o marco histórico das Constituições do México, de 1917 e de Weimar, de 1919. Este constitucionalismo social influenciou diretamente a Constituição brasileira de 1934 (Estado Social de Direito).

O constitucionalismo contemporâneo, mais recente, é caracterizado pelos textos sedimentados em conteúdo social, estabelecendo normas programáticas, cujo exemplo primoroso é a Constituição Federal de 1988.

No Direito estrangeiro, parte dos ordenamentos relativos à proteção à maternidade encontra-se em leis específicas e não em textos constitucionais, como o caso dos países nórdicos, como Noruega, Dinamarca e Suécia ${ }^{17}$. A licença-maternidade remunerada tem duração de 36 semanas na Noruega, 18 semanas na Dinamarca e 14 na Suécia. No caso da Dinamarca, a licença é disciplinada pela Lei n. 234 de 4 de junho de 1980, complementada pela Lei n. 101, de 6 de março de 1987.

${ }^{16}$ Cf. ORGANIZAÇÃO INTERNACIONAL DO TRABALHO. Trabalho e familia: rumo a novas formas de conciliação com co-responsabilidade social. Brasília: OIT, 2009.

${ }^{17}$ Cf. BARROS, Alice Monteiro de. A mulher e o direito do trabalho. São Paulo: LTr, 1995. 
Já na França, diferentemente dos exemplos citados, a proteção à maternidade é tratada no Código de Trabalho, especificamente na Seção V, II do Título II do Livro $1^{\circ}$.

No caso da Itália, por sua vez, a Constituição trata do princípio da não discriminação projetando especial proteção ao trabalho da mulher e à maternidade, promovendo a proteção da mãe, da criança e da relação de ambos no estágio de licença definido por lei infraconstitucional. Vejamos:

Art. 37 - La donna lavoratrice há gli stessi diritti e, a parità di lavoro, le stesse retribuzioni che spettano al lavoratore. Le condizioni di lavoro devono consentire l'adempimento della sua essenziale funzione familiare e assicurare allá madre e al bambino uma speciale adeguata protezione. La legge stabilisce il limite minimo di età per il lavoro salariato. La Repubblica tutela il lavoro dei minori com speciali norme e garantisce ad essi, a parità di lavoro, il diritto alla parità di retribuzione ${ }^{18}$.

Afirmando o imperativo constitucional, vale ressaltar que uma ação legislativa adequada foi realizada na Itália com objetivo de permitir à mulher, segundo o definido na Constituição, a realização de sua função essencial familiar, assegurando à mãe e à criança uma especial e adequada proteção (art. 37, $\S 1^{\circ}$ ). No que se refere à jurisprudência constitucional, importante dizer que a Sentença 270 de 1999 declarou a inconstitucionalidade na Lei 1.204/1971, intitulada "Tutela das Mães que Trabalham”, na parte em que não prevê para a hipótese de parto prematuro, prazos adequados que possam propiciar à mãe e à criança uma tutela adequada ( $\operatorname{art.} 4^{\circ}, \S 1^{\circ}$ da referida Lei).

Assim, nota-se a força e a respeitabilidade da Constituição italiana em promover a proteção da mãe e da criança, além de reforçar o instituto próprio que define a licençamaternidade, que neste caso é de 150 dias. Caso a Corte italiana entenda que qualquer legislação infraconstitucional não esteja em harmonia com o comando constitucional, que visa à possibilidade de a mulher cumprir sua função familiar, esta lei será objeto de controle de constitucionalidade jurisprudencial, conforme exemplo.

18 Constituição Italiana, art. 37. Versão em espanhol: "La mujer trabajadora tendrá los mismos derechos y, a igualdad de trabajo, la misma retribución que el trabajador. Las condiciones de trabajo deberán permitir a la mujer el cumplimiento de su misión familiar esencial y asegurar a la madre y al niño una protección especial adecuada. La ley establecerá el limite máximo de edad para el trabajo asalariado. La República protegerá el trabajo de los menores com normas especiales y lês garantizará, para trabajos iguales, el derecho a la igualdad de retribución." 
É verdade que o Direito estrangeiro tem influenciado as legislações nacionais na maior parte dos países da América Latina, quando o assunto é relacionado ao trabalho. Contudo, há uma diversidade de instrumentos legais e de sistemas de proteção à maternidade no que diz respeito ao período do afastamento e aos benefícios garantidos por lei nos países da América Latina e Caribe ${ }^{19}$.

Outro aspecto importante no Direito estrangeiro é que a questão do trabalho feminino não é abordada somente em relação à extensão ou duração da licençamaternidade. Se na América Latina e Europa constata-se uma tendência geral de aceitação da importância do afastamento pelo tempo adequado no pós-parto, alguns países, concomitantemente, pensam em políticas públicas para preservar o vínculo de emprego da mão-de-obra feminina, para que estas mulheres possam gozar deste benefício e ainda possam continuar conciliando a atividade familiar e profissional.

Na Alemanha, a exemplo do que nos relata o jurista alemão Wolfgang Däubler ${ }^{20}$, o direito trabalhista reage sob três aspectos quanto a isso. Em primeiro lugar, há um consenso já sedimentado de que qualquer discriminação em relação ao sexo é proibida e se manifesta na fixação das faixas salariais e na concessão de adicionais, já que lá as políticas salariais dos sindicatos e das empresas estão sujeitas a prática de correção pelo Estado (ainda que de maneira limitada).

A Suprema Corte Européia tem tomado decisões contra a discriminação indireta, o que se refletiu na proteção ao trabalho da mulher, já que esta mesma Corte proibiu que empregados com jornada reduzida sejam excluídos de benefícios, como o fundo de pensão da empresa e da pensão por doença (lá, cerca de 90\% de trabalhadores com jornada reduzida são mulheres.

A respeito do Direito Comunitário, cumpre observar que o tratamento dispensado ao combate à discriminação de gênero é admirável. Há uma vasta atenção dada ao tema, principalmente buscando promoção da igualdade de renda e oportunidades. No entanto, alguns doutrinadores advertem que a atenção dada à questão de gênero como forma de promoção da igualdade deve sempre ser acompanhada do empoderamento da Suprema Corte Européia em decidir, com base no Tratado de Amsterdã, questões conflituosas de raça, religião, opção sexual etc., na busca da promoção da integral igualdade (de modo que

${ }^{19}$ Cf. ORGANIZAÇÃO INTERNACIONAL DO TRABALHO. Trabalho e família: rumo a novas formas de conciliação com co-responsabilidade social. Brasília: OIT, 2009, cap. 3.

${ }^{20}$ DÄUBLER, Wolfgang. Direito do trabalho e sociedade na Alemanha. São Paulo: LTr, 1997. 
essa busca não se restrinja à questão de gênero). A doutrinadora italiana Luisa Galatino, refletindo sobre esta questão, adverte:

"Se il principio della parità di trattamento tra uomini e donne è ormai da tempo consolidato in consistente corpus di norme comunitarie, va posto in evidenz che il Trattato di Amsterdam espressamente conferisce al Consiglio il potere di prendere i provvedimenti opportuni per combattere le discriminazioni fondate non solo sul sesso, ma anche sulla razza, sull'origine etnica, sulla religione, sulle convinzioni personali, sugli handicap, sull'età o sulle tendenze sessuali, ${ }^{21}$.

Note-se que a Alemanha vem discutindo como criar real igualdade de oportunidades, já que a proibição de discriminação não resolve, por si, o problema. Houve algumas discussões a respeito de cotas para mulheres, mas nada de concreto se determinou sobre isso. De qualquer maneira, todas estas medidas, somadas com a licença-maternidade, que hoje é de até 2 anos (um período remunerado, outro não), vem colocando o Direito e o Estado alemães entre os países mais avançados no que diz respeito à proteção à maternidade.

Por outro lado, é importante apontar que a cobertura e o conteúdo da proteção à maternidade variam muito de país para país. Ou seja, ainda hoje, há muitas mulheres que não têm garantido sequer o direito à licença-maternidade, dependendo do tipo de inserção no mercado de trabalho e do modelo de proteção social vigente. No caso dos países em desenvolvimento, certamente, esse problema é bem mais grave. De acordo com relatório publicado em conjunto pela OIT e pelo PNUD:

\begin{abstract}
"Um problema ainda mais premente é a ausência de cobertura universal. Ao contrário, tendo em vista múltiplas exclusões, se produz uma brecha de execução, ou seja, uma proporção importante de trabalhadoras e trabalhadores fica fora do alcance da lei, sem possibilidade de usufruir destes direitos. A primeira exclusão decorre da limitação da cobertura da legislação a assalariados formais: os trabalhadores informais, por definição, se inserem entre os excluídos. A informalidade no trabalho é uma modalidade endêmica de
\end{abstract}

${ }^{21}$ GALANTINO, Luisa. Diritto comunitario del lavoro. Torino: G. Giappichelli Editore, 2001, p. 191. Tradução livre: "Se o princípio da igualdade de tratamento entre homens e mulheres tem sido estabelecido no vasto corpo da legislação comunitária, devem ser colocados na mostra que o Tratado de Amsterdã dá explicitamente ao Conselho o poder de tomar medidas adequadas para combater a discriminação não só de sexo, mas também de raça, origem étnica, religião, crença, deficiência, idade ou orientação sexual." 
exclusão em muitos países da região, o que, por sua vez, acarreta baixa cobertura da previdência social. Este tema é preocupante, sobretudo para as mulheres, pois, mais de $50 \%$ das trabalhadoras estão no setor informal na América Latina e Caribe. Como resultado, estas mulheres não contam com o direito à proteção à maternidade, carecem de reconhecimento de sua condição, licença-maternidade e tempo remunerado para amamentação."22

Estudo recente publicado pela OIT referente às disposições legislativas nacionais que regem a proteção à maternidade em 167 países permite observar a diversidade de situações encontradas nos diferentes continentes ${ }^{23}$. É possível constatar que, em geral, nos países economicamente mais atrasados são maiores as proporções de mulheres que não podem desfrutar de um período de licença do trabalho, nem dispõem de condições necessárias para conciliar trabalho e família. Mas, de acordo com o relatório, tem havido uma ampliação perceptível da proteção legal básica. As principais tendências verificadas entre 1994 e 2009 são as seguintes: aumento gradual do período de licença-maternidade, melhoria do valor pago (taxa de reposição) e paulatina retração do modelo de financiamento que responsabiliza o empregador pelo pagamento da prestação.

Na maioria dos países investigados a duração da licença se manteve constante ou aumentou neste período (ver Tabela A-1 no Anexo II). A proporção de países que propiciam menos de 12 semanas de licença diminuiu (de 19\% para 14\% entre 1994 e 2009), enquanto cresceu o número dos que oferecem licenças mais prolongadas (a proporção de países que asseguram de 14 a 17 semanas passou de $29 \%$ para $35 \%$, e a porcentagem dos que asseguram 18 semanas ou mais passou de 9\% para 13\%). Por sua vez, a taxa de reposição aumentou em 17 países.

A porcentagem de países que utilizam sistemas de responsabilidade do empregador tem diminuído com o tempo (de $31 \%$ para $26 \%$ ), enquanto tem aumentado a proporção de sistemas mistos em que os empregadores e a previdência social dividem a responsabilidade das prestações (de 14\% para 20\%). A porcentagem de países que utilizam somente sistemas de previdência social para financiar a proteção à maternidade - que é o melhor

22 ORGANIZAÇÃO INTERNACIONAL DO TRABALHO. Trabalho e família: rumo a novas formas de conciliação com co-responsabilidade social. Brasília: OIT, 2009, p. 88.

${ }^{23}$ ORGANIZACIÓN INTERNACIONAL DEL TRABAJO. La maternidad en el trabajo: examen de la legislación nacional. 2. ed. Ginebra: OIT, 2010. 
modelo quando se pretende combater a discriminação por gênero - se manteve num nível constante de 50\% entre 1994 e 2009 (ver Tabela A-2 no Anexo II).

Em síntese, a efetivação do direito constitucional de proteção à maternidade e a ampliação de seu escopo, em especial por meio de mudanças na legislação infraconstitucional, têm sido importantes para melhorar a condição das mulheres em países com distintos padrões de desenvolvimento. É oportuno transcrever um trecho da conclusão do estudo da OIT:

"En general, las normas sobre protección de la maternidad han ido mejorando con el tiempo. En la actualidad, los paises que prevén una remuneración durante la licencia de maternidad son más que en 1994 y ha disminuido el número de países que atribuyen exclusivamente a los empleadores el pago de las prestaciones pecuniarias de maternidad. No obstante, deberian ser más los paises que, a fin de proteger la maternidad de manera óptima, intentaran incorporar a su legislación todos los aspectos del Convenio núm. 183. En algunos ámbitos se puede reforzar la protección de la maternidad. Por ejemplo, algunas trabajadoras no la tienen porque muchos países excluyen de sus disposiciones sobre protección de la maternidad a ciertas categorías de trabajadoras, como las del servicio doméstico y la agricultura. Para los Estados Miembros de la OIT debería constituir una prioridad que todas las trabajadoras sin discriminación alguna, incluso las que ejercen formas atípicas de trabajo, tuvieran acceso a la protección.

Ampliar a ambos padres los tipos disponibles de licencia es otro ámbito necesitado de mayor atención. Algunos países ya prevén licencia de paternidad y licencia parental, habitualmente durante los primeros años de la vida del hijo. Estos tipos de licencia pueden ayudar a los trabajadores que acceden a ellos a conciliar el trabajo y la vida familiar y, si dicho acceso está al alcance tanto de los padres como de las madres, pueden ser instrumentos eficaces para el fomento de la igualdad de género." 24

Convém explicitar que não há uma correspondência obrigatória entre o grau de desenvolvimento econômico e social, de um lado, e o patamar da proteção à maternidade, de outro. Há diferenças significativas em termos de duração da licença-maternidade e da taxa de reposição entre países com nível de renda per capita semelhante. De qualquer modo, não há dúvida de que países com alto índice de desenvolvimento humano, grosso

${ }^{24}$ ORGANIZACIÓN INTERNACIONAL DEL TRABAJO. La maternidad en el trabajo: examen de la legislación nacional, 2010, p. 99. 
modo, tendem a apresentar um sistema mais avançado de proteção à maternidade, como pode ser constatado nos quadros a seguir.

\section{Quadro 1}

Duração da licença-maternidade paga e obrigatória (em dias) para países com Índice de Desenvolvimento Humano muito elevado

\begin{tabular}{|c|c|c|}
\hline País & IDH - 2010 & Licença-maternidade \\
\hline Noruega & 0,938 & 126 \\
\hline Austrália & 0,937 & 0 \\
\hline Nova Zelândia & 0,907 & 98 \\
\hline Estados Unidos & 0,902 & 0 \\
\hline Irlanda & 0,895 & 182 \\
\hline Holanda & 0,890 & 112 \\
\hline Canadá & 0,888 & 119 \\
\hline Suécia & 0,885 & 98 \\
\hline Alemanha & 0,885 & 98 \\
\hline Japão & 0,884 & 98 \\
\hline Coreia do Sul & 0,877 & 60 \\
\hline Suíça & 0,874 & 112 \\
\hline França & 0,872 & 112 \\
\hline Israel & 0,872 & 84 \\
\hline Finlândia & 0,871 & 263 \\
\hline Islândia & 0,869 & 180 \\
\hline Bélgica & 0,867 & 105 \\
\hline Dinamarca & 0,866 & 126 \\
\hline Espanha & 0,863 & 112 \\
\hline Hong Kong & 0,862 & 70 \\
\hline Grécia & 0,855 & 119 \\
\hline Itália & 0,854 & 150 \\
\hline Áustria & 0,851 & 112 \\
\hline Reino Unido & 0,849 & 365 \\
\hline
\end{tabular}

Fonte: PNUD. Relatório de desenvolvimento humano, 2010. Elaboração própria.

No Quadro 1, chama atenção a ausência de uma legislação federal nos Estados Unidos e na Austrália, países que estão entre os que apresentam maiores índices de desenvolvimento humano, estabelecendo um sistema obrigatório e pago de licençamaternidade. Por sua vez, no Reino Unido o período de licença concedido pode chegar a 1 ano. Suécia, Alemanha, Japão e Nova Zelândia contam com legislação que garante o período mínimo estabelecido por convenção internacional da OIT (14 semanas). 


\section{Quadro 2}

Duração da licença-maternidade paga e obrigatória (em dias) para países com Índice de Desenvolvimento Humano elevado

\begin{tabular}{|lcc|}
\hline \multicolumn{1}{|c}{ País } & IDH - 2010 & Licença-maternidade \\
\hline Lituânia & 0,783 & 126 \\
Chile & 0,783 & 126 \\
Argentina & 0,775 & 90 \\
Croácia & 0,767 & 365 \\
Uruguai & 0,765 & 84 \\
Panamá & 0,755 & 98 \\
Arábia Saudita & 0,752 & 70 \\
México & 0,750 & 84 \\
Malásia & 0,744 & 60 \\
Bulgária & 0,743 & 135 \\
Sérvia & 0,735 & 365 \\
Costa Rica & 0,725 & 120 \\
Peru & 0,723 & 90 \\
Rússia & 0,719 & 140 \\
Ucrânia & 0,710 & 126 \\
Brasil & 0,699 & 120 \\
Venezuela & 0,696 & 126 \\
Equador & 0,695 & 84 \\
Colômbia & 0,689 & 84 \\
Turquia & 0,679 & 112 \\
\hline
\end{tabular}

Fonte: PNUD. Relatório de desenvolvimento humano, 2010. Elaboração própria.

No Quadro 2, a heterogeneidade se repete. Entre os países selecionados do segundo escalão em termos de desenvolvimento humano, também há casos em que o período de licença-maternidade obrigatória e remunerada é menor do que o sugerido pela OIT, assim como há casos em que o período é de 1 ano. Pode-se notar que a licença-maternidade no Brasil tem duração bem maior do que em muitos países do primeiro e do segundo grupos, mesmo sem considerar a expansão facultativa para seis meses (180 dias).

No Quadro 3, com alguns países que apresentam um índice de desenvolvimento humano médio, percebe-se que a duração da licença-maternidade tende a ser inferior ao estabelecido pela OIT, com poucas exceções. A situação é ainda mais grave entre países com baixos níveis de IDH, para os quais não foi elaborado um quadro específico. 


\section{Quadro 3}

Duração da licença-maternidade paga e obrigatória (em dias) para países com Índice de Desenvolvimento Humano médio

\begin{tabular}{|lcc|}
\hline \multicolumn{1}{|c}{ País } & IDH - 2010 & Licença-maternidade \\
\hline República Dominicana & 0,663 & 84 \\
China & 0,663 & 90 \\
Bolívia & 0,643 & 60 \\
Paraguai & 0,640 & 84 \\
Filipinas & 0,638 & 60 \\
Egito & 0,620 & 90 \\
Honduras & 0,604 & 70 \\
Indonésia & 0,600 & 90 \\
África do Sul & 0,597 & 112 \\
Vietnã & 0,572 & 120 \\
Marrocos & 0,567 & 98 \\
Nicarágua & 0,565 & 84 \\
Índia & 0,519 & 84 \\
\hline
\end{tabular}

Fonte: PNUD. Relatório de desenvolvimento humano, 2010. Elaboração própria.

Por fim, algumas palavras do relatório do PNUD para reflexão:

“A história é encorajadora, mas pede cautela. É encorajadora porque o progresso é possível mesmo sem grande volume de recursos: a maioria dos países tem os meios para melhorar as vidas das pessoas. E pede cautela porque o sucesso não é garantido e porque os percursos para o sucesso variam e são específicos das condições institucionais, políticas e históricas de um país. Em vez de pensarmos em receitas políticas universais, podemos aplicar princípios fundamentais para informar o pensamento acerca das estratégias e políticas de desenvolvimento. [...]

Uma abordagem às políticas centrada em princípios básicos e não em recomendações universais assemelha-se à abordagem do pensamento sobre a justiça apresentado anteriormente, mostrando que é possível identificar possibilidades para o progresso no melhoramento das vidas das pessoas sem que haja um pleno acordo quanto à definição exacta do que seria uma sociedade ideal." 25

25 PROGRAMA DAS NAÇÕES UNIDAS PARA O DESENVOLVIMENTO. Relatório de Desenvolvimento Humano 2010. New York: PNUD, 2010, cap. 3, p. 68. 


\subsection{Trajetória da proteção à maternidade no Brasil}

A ampliação e a valorização do trabalho da mulher no Brasil (e num número crescente de países) representam uma quebra de paradigma com o modelo mulher-trabalho doméstico, homem-sustento da família, que durante séculos predominou em sociedades forjadas pelo patriarcado rural. Mesmo à medida que avançava a urbanização, os homens continuaram tendo o monopólio da ação social produtiva, sendo valorizado apenas o trabalho fora de casa e ficando sobrepujada a importância da atuação da mulher, que se destinava quase exclusivamente ao trabalho doméstico, ao cuidado do lar e dos filhos, às vezes à produção para o consumo próprio.

Uma retrospectiva das lutas para valorizar e proteger o trabalho da mulher no Brasil talvez não difira de forma substantiva de outras experiências internacionais, mas certamente é marcada por recortes específicos, condizentes com a história do País. A legislação pertinente ao trabalho da mulher se harmonizou, em partes, com as transformações que o tema sofreu ao longo das décadas. Sob o campo do Direito ou da Sociologia, o que se constatam são as mudanças de paradigma do próprio sistema industrial, antes sedimentado na mão-de-obra essencialmente masculina. Mas, certamente, o campo da Política também jogou um peso relevante nessa trajetória.

Digamos que a história do trabalho da mulher no Brasil pode ser dividida em eras ou épocas definidas por marcos jurídicos ${ }^{26}$. Numa primeira fase, a mulher era excluída do mundo do trabalho e confinada no lar sob dominação masculina, ou tinha uma participação econômica tutelada - este período vai desde o ordenamento da República Velha (1891) até a Revolução de 1930. Na segunda fase, pode-se falar que começa a emancipação legal e a proteção do trabalho da mulher - este período se inaugura com a Constituição de 1934 e, em particular, a promulgação da CLT (1943), indo até o momento de transição aberto pela Nova República (1985). A terceira onda, sob esta ótica, corresponde à consolidação dos direitos sociais, à ênfase na igualdade no trabalho e à maior efetividade da atuação das mulheres como atores sociais - este período parte da promulgação da Constituição Cidadã de 1988 e segue até os dias de hoje.

${ }^{26}$ Esta ideia de "eras" ou "ondas" foi apresentada pela Professora Léa Calil. Cf. CALIL, Léa Elisa Silingowschi. História do direito do trabalho da mulher: aspectos histórico-sociológicos do início da República ao final deste século. São Paulo: LTr, 2000. 
No Brasil, conforme apontam Ellen Hardy e Maria José Osis ${ }^{27}$, muito embora as mulheres representassem um enorme contingente de mão-de-obra empregada na indústria brasileira no final do século XIX e início do século XX, leis que protegessem o seu trabalho foram efetivadas somente muito mais tarde.

Em 1923, surge um decreto regulamentando o trabalho feminino (em especial em relação a sua condição de mãe) em todo o país. É um verdadeiro marco legislativo de nossa história, conforme informam Hardy e Osis:

“O Decreto n. 16.300, de dezembro de 1923, determinava, nos artigos 348 e 350, que os estabelecimentos industriais e comerciais em que houvesse trabalhadoras que estivessem amamentando seus filhos deveriam proporcionar-lhes a possibilidade de fazê-lo. Estipulava, também, que deveria haver creches ou salas de amamentação localizadas próximo a esses estabelecimentos, onde as mães poderiam amamentar duas ou três vezes por dia em intervalos regulares" 28 .

Mas é apenas na Constituição de 1934 que se fala em proteção à maternidade e também à infância. Em seu artigo 138, nos incisos "c" e "f", essa Constituição dizia que incumbia à União, aos Estados e Municípios, nos termos das leis respectivas: c) amparar a maternidade e a infância; e f) adotar medidas legislativas e administrativas tendentes a restringir a morbidade e a mortalidade infantis. As Constituições que se seguiram mantiveram basicamente o mesmo espírito a respeito da proteção à maternidade e à infância.

A proteção à mulher, à mãe, à amamentante e à infância passou, assim, a fazer parte de nossas leis máximas, como parte integrante do que se convencionou, em nossa sociedade, chamar de "pacote social" nas Constituições. Este movimento ocorreu a despeito da resistência dos empregadores, que vieram a se sentir ameaçados pela "abrangência" exagerada de tais cláusulas em textos constitucionais.

Porém, tal elevação constitucional permitiu que tais direitos fossem, de fato, efetivados e respeitados, consolidando o novo formato do Estado Democrático de Direito que se solidificou com a Carta Magna de 1988.

\footnotetext{
${ }^{27}$ HARDY, Ellen E; OSIS, Maria José. Mulher, trabalho e amamentação: legislação e prática. Campinas: Editora da Unicamp, 1991.

${ }^{28}$ HARDY, Ellen E.; OSIS, Maria José. Mulher, trabalho e amamentação, 1991, p. 51.
} 
O reconhecimento da proteção à maternidade nas constituições brasileiras como um direito social também simbolizou a grande influência destes movimentos internacionais no ordenamento nacional, assim como a inclusão de outros direitos chamados, mais tarde, “direitos de segunda geração" (ou segunda dimensão) ${ }^{29}$.

Assim, de modo geral e observando os ordenamentos diversos, pode-se afirmar que, no século $\mathrm{XX}$, os textos Constitucionais foram trazendo ao seu bojo uma série de comandos relativos primeiramente à igualdade entre os sexos e, em seguida, à proteção ao trabalho da mulher. Tais comandos foram se ampliando para a proteção às gestantes e lactantes, visando à saúde da trabalhadora e do recém-nascido.

Parece oportuno recuar no tempo para mencionar, brevemente, aspectos que ajudam a visualizar momentos de inflexão. Inicialmente, é preciso lembrar que o texto constitucional de 1824 não se refere especificamente ao trabalho da mulher, mas menciona que a lei seria igual para todos (art. 178, XII). Note-se, apenas uma parcela restrita da população tinha acesso aos direitos civis e políticos.

Já o texto de 1891, ao assegurar o princípio da igualdade e abolir as regalias de nobreza, trouxe avanços no que se refere à inclusão de parcela maior da população na ordem legal, porém, omitiu-se em relação ao trabalho da mulher.

A Constituição de 1934 significou um verdadeiro avanço neste aspecto, ao dispor sobre igualdade de salários entre homens e mulheres, proibição de trabalho em condições insalubres, assistência médica e sanitária à gestante, descanso antes e depois do parto, sem prejuízo do salário e do emprego.

Este diploma foi um marco, porque destacou os até então não mencionados direitos de maternidade. Além da garantia do descanso remunerado, outros foram os direitos vislumbrados, como previdência em favor da maternidade e infância, impondo contribuições específicas da União, estados e municípios para tanto (1\% da arrecadação tributária).

Já a CF de 1937 (que deu sustentação ao Estado Novo) retrocedeu na concessão de igualdade de salários entre homens e mulheres, autorizando um desfavor de $10 \%$ para estas, mantendo os demais dispositivos protetivos.

${ }^{29} \mathrm{Na}$ perspectiva de Norberto Bobbio, direitos de primeira geração incluem: liberdades individuais, públicas e direitos políticos; direitos de segunda geração: direitos sociais, culturais e econômicos; direitos de terceira geração: preservação ambiental e direito dos consumidores; direitos de quarta geração: ligados ao patrimônio genético humano. BOBBIO, Norberto. A era dos direitos. Rio de Janeiro: Elsevier, 2004. 
Assim como a Carta de 1934, as de 1946 e 1967, inclusive a emenda de 1969, em seus artigos 158, III e 165, III, proibiam salários diferentes entre homens e mulheres, além de assegurarem todos os outros direitos concedidos anteriormente. Mas o grande destaque da Constituição de 1967 é que esta inovou à medida que proibiu a diferença de critérios de admissão por motivo de sexo, cor e estado civil e assegurou a aposentadoria à mulher após trinta anos de contribuição.

A Constituição Cidadã de 1988 assegurou, em seu artigo 5º, I, a igualdade de direitos e obrigações entre homens e mulheres, proibindo diferença de salários, de exercício de funções e de critérios de admissão por motivos de sexo, estado civil, idade e cor. Alongou a licença-maternidade de 90 para 120 dias, sem prejuízo do emprego e do salário, inclusive para as domésticas, avulsas e rurais.

Outro avanço importante, conquista no campo dos direitos sociais, foi a garantia do emprego da gestante desde a confirmação da gravidez até cinco meses após o parto, vedando a sua dispensa neste período.

Além disso, na $\mathrm{CF} / 88$ o salário-maternidade foi estendido à empregada doméstica $\mathrm{e}$ à avulsa, por força do artigo $7^{\circ}$, parágrafo único, tendo como fonte de custeio a Previdência Social. Em 1994, a segurada especial passou a ter direito ao salário-maternidade (um salário mínimo), desde que comprove a atividade rural, ainda que de forma descontínua, nos doze meses anteriores ao início do benefício, conforme artigo 39 da Lei n. 8.213, com redação atual da Lei 8.861 de 1994. Encontram-se excluídas as estagiárias e autônomas, embora sejam seguradas obrigatórias da Previdência Social.

Sobre a matéria previdenciária relativa à proteção à maternidade, teceremos alguns comentários no último capítulo deste trabalho.

Por fim, é importante enfatizar que o Brasil, assim como vários outros países, sofreu grande influência de organismos internacionais para que criasse uma regulamentação protetiva à mulher. Mas, tal influência não explica o salto na proteção constitucional oferecida especificamente no caso da licença-maternidade. De fato, como foi indicado na seção anterior, o desenvolvimento econômico e a consolidação da democracia podem ajudar a viabilizar avanços significativos nesta área protetiva, mas igualmente não explicam o estágio alcançado. Foi necessária a presença de forças políticas favoráveis para que a resistência fosse vencida e houvesse um avanço significativo nesta direção. 


\section{CAPÍTULO 2}

\section{O DEBATE ACERCA DA EXTENSÃO DA LICENÇA- MATERNIDADE NA ASSEMBLÉIA CONSTITUINTE (1987-1988) E SEUS DESDOBRAMENTOS}

A Constituição Cidadã de 1988 assegurou, conforme argumentado antes, a igualdade de direitos e obrigações entre homens e mulheres, proibindo diferença de salários, de exercício de funções e de critérios de admissão por motivos de sexo, estado civil, idade e cor. Também prolongou a licença-maternidade de 90 para 120 dias, sem prejuízo do emprego e do salário, inclusive para as domésticas, avulsas e rurais.

Notadamente, resultou numa conquista de importantes direitos sociais relativos à maternidade e outros tantos, revelando seu aspecto social e voltado para a igualdade social, movimento que não se deu sem oposições e debates.

Importante, inicialmente, revisitar o cenário político-econômico da Constituinte e a importância dada aos direitos trabalhistas. A intenção aqui é situar a mudança constitucional não apenas no tempo cronológico, mas no contexto social em que se deram os debates acerca da Constituinte. E poder, ao final da seção, enfatizar que houve muitas resistências à ampliação dos direitos sociais e à aprovação da Constituição.

De fato, a mídia nacional colocou o assunto em evidência, veiculando notícias diariamente sobre o andamento dos trabalhos dos constituintes, entre meados de 1987 e outubro de 1988.

Neste período, a situação política brasileira era bastante conturbada, já que vivíamos em tempos de transição para um regime democrático. A Nova República tinha prometido enterrar o entulho autoritário e resgatar a dívida social do País, mas os setores conservadores tinham outras prerrogativas. 
A situação econômica do período era difícil: após a euforia do Plano Cruzado em 1986, o País foi obrigado a pedir moratória da sua dívida externa, enquanto a inflação voltou a aumentar de forma descontrolada. E é preciso ter em vista que, entre o final de 1987 e o início de 1988, a economia brasileira sofreu uma desaceleração impactante, relacionada com a queda da Bolsa de Nova York (em 19 de outubro de 1987, o Dow Jones sofreu a maior queda em tempos de paz: com uma queda de $22 \%$, o "crash" se alastrou às bolsas da Europa e do Japão). Neste contexto hostil, as tentativas de estabilizar a economia nacional com planos econômicos vinham fracassando ${ }^{30}$.

Não obstante o quadro econômico instável e a situação política conturbada, o Brasil promulgou uma nova Constituição Federal a partir de 1988 com importantes inovações institucionais. Pela primeira vez, por exemplo, a Constituição estabelecida em ambiente de consolidação democrática se propôs a valorizar o trabalho humano, com inegável compromisso de internalizar bases legais de proteção social e trabalhista comparáveis às de países do centro do capitalismo mundial. A desembargadora aposentada e pesquisadora Magda Barros Biavaschi estabelece uma comparação com a Constituição de Weimar nos seguintes termos:

“Comparando-se as duas Constituições constatam-se grandes similitudes. Ambas atribuem valor social ao trabalho e à propriedade, limitando esta à sua função social. Ambas condicionam a livre iniciativa ao valor social do trabalho [...]. Tanto os constituintes alemães, em 1919, como os brasileiros, em 1988, apostaram num pacto legítimo e justo, dirigindo o princípio da igualdade ao Executivo, Judiciário e Legislativo. Para cumprimento da isonomia $\left[\mathrm{CF}\right.$, art. $5^{\circ}$ ], amalgamada nos princípios da dignidade humana e do valor social do trabalho $\left[\mathrm{CF}\right.$, art. $\left.1^{\circ}\right]$, partindo da compreensão das brutais desigualdades constituintes da sociedade brasileira, a Lei Maior inscreveu instrumentos que possibilitam que os desiguais sejam tratados desigualmente para que maiores patamares de igualação sejam atingidos. Adotando a compreensão da liberdade positiva e buscando assegurar a todos a igualdade, os Constituintes de 1988, como os de Weimar, em 1919, elegeram como valor fundamental a garantia da igualdade substantiva, numa via em que direitos sociais fundamentais impõem à democracia limites específicos. Assim, foi abandonada a ideia meramente negativa da igualdade, optando-se pela igualdade positiva expressa na exigência do art. $1^{\circ} \mathrm{III}$ e IV e do art. $5^{\circ}$ que assegura o direito à igualdade. E no art. 170, ao definir os fundamentos da Ordem Econômica, condicionou-a à existência digna de todos os

${ }^{30}$ Cf. CARNEIRO, Ricardo. Desenvolvimento em crise: a economia brasileira no último quarto do século XX. São Paulo: Ed. Unesp; Unicamp.IE, 2002. 
cidadãos e aos princípios da Justiça Social, lançando as bases para o Estado Social de Direito." 31

Em termos de igualdade de gênero no mundo do trabalho, a Constituição também representou um considerável avanço. O movimento feminista e das mulheres havia sido muito ativo desde os anos 1970, não apenas na luta pela melhoria das condições de vida, como também no questionamento ao regime autoritário. Portanto, essa trajetória e esse acúmulo de experiências, no momento de instalação do Congresso Constituinte o movimento está pronto para apresentar uma extensa pauta de ampliação de direitos, assim como manter uma intensa mobilização durante todo o processo na tentativa de conquistar um espaço maior em várias áreas ${ }^{32}$.

Não cabe aqui analisar o teor da nova Constituição que guiaria o país em tempos inovadores de Estado Democrático de Direito combinado com uma ampliação substantiva da cidadania. Mas, sem dúvida, é importante conhecer os discursos que originaram os debates acerca do tema em questão. Este é um passo necessário para uma investigação embasada a respeito da hipótese que norteia este estudo, a saber: a ampliação da proteção social, principalmente à maternidade, pode constituir ferramenta para o aperfeiçoamento da eficácia da proteção.

E mais, procura-se aqui provar que os argumentos proclamados (naquela época e ainda hoje) pelos atores conservadores, de modo ideológico e contrafactual, a respeito da possível queda da participação feminina no mercado de trabalho e do peso excessivo dos encargos (que arrasaria grande parte das empresas), não se sustentam. Usando o jargão jurídico: "contra fatos não há argumentos".

${ }^{31}$ BIAVASCHI, Magda B. Relações e condições de trabalho no Brasil contemporâneo: garantir direitos e promover a igualdade, in: KREIN, José Dari; SANTANA, Marco Aurélio; BIAVASCHI, Magda (Orgs.). Vinte anos da Constituição cidadã no Brasil. São Paulo: LTr, 2010, p. 157.

32 "As deputadas constituintes se organizaram em uma força-tarefa que reunia mulheres dos mais variados partidos e movimentos sociais e que passou a ser conhecido como o lobby do batom [...]. Sob o lema Constituinte pra valer tem que ter palavra de mulher!, o grupo elaborou emendas populares e recolheu milhares de assinaturas por todo o País [...]. Como resultado desse processo uma série de avanços se plasmaram na Constituição de 1988.” ABRAMO, Laís. A Constituição de 1988 e o mundo do trabalho no Brasil, in: KREIN, José Dari; SANTANA, Marco Aurélio; BIAVASCHI, Magda (Orgs.). Vinte anos da Constituição cidadã no Brasil, 2010, pp. 25-26. 


\subsection{Discursos sobre a ampliação da proteção à maternidade}

Buscando os fatos históricos, esta seção procura apresentar os discursos acerca da extensão da licença-maternidade à época dos trabalhos da Constituinte. Para isso, foi realizada uma pesquisa nos registros históricos, ou seja, jornais, revistas e veículos populares que acompanharam o processo democrático em comento.

Os veículos de comunicação pesquisados foram a Revista Veja e os jornais Folha de São Paulo e o Estado de São Paulo, além de jornais de sindicatos e associações de trabalhadores.

Os acervos pesquisados foram o Arquivo Público do Estado de São Paulo e o AEL - Arquivo Edgard Leuenroth da Universidade Estadual de Campinas - Unicamp. A compilação das falas dos atores políticos e de comentários de analistas priorizou os argumentos que informam o debate acerca da extensão não só da licença-maternidade, mas do alargamento constitucional em relação aos direitos sociais, sob a visão dos trabalhadores e sob a visão dos empregadores.

Extremamente interessante voltar no tempo e revisitar "falas" de todos os meios midiáticos e técnicos a respeito do assunto, que podem nos revelar temores e anseios de uma época que se convencionou chamar de "época de transição democrática".

Os exemplares de revistas pesquisados no acervo público da Veja foram os publicados nos anos de 1987 e 1988, sendo selecionados seis exemplares cujas informações interessavam à investigação deste estudo ${ }^{33}$.

Em 1987, os grupos femininos passaram a acompanhar e comemorar o destaque que os direitos da mulher conquistaram no anteprojeto da Constituição, visivelmente ultrapassada sob vários aspectos da realidade social daquele momento.

Pelo anteprojeto, a mulher passaria a ter os mesmos direitos do homem na família, o casamento deixaria de ser a única forma de constituição de família, acabariam as figuras jurídicas de mãe solteira e também do filho ilegítimo (muito comumente chamado de bastardo).

33 Revista Veja, edições de: 03/06/1987, 02/03/1988, 30/03/1988, 27/04/1988, 07/09/1988 e 19/10/1988. 
As mulheres também poderiam, como de fato ocorreu, conseguir o divórcio após dois anos de separação. Todos estes componentes do anteprojeto indicaram que a Constituição de 1988 criaria um mundo melhor para as mulheres brasileiras.

Na ocasião, a atriz Regina Duarte, que ativamente acompanhou os trabalhos da Constituinte e era protagonista do popular programa feminino da TV Globo "Malu Mulher", declarou: "é bom que isto conste em Lei, ainda que se trate de uma reivindicação bem antiga" ${ }^{34}$.

Segundo a então deputada Eunice Michiles, do PFL, estas eram as maiores vitórias femininas de todos os tempos ${ }^{35}$.

Assim, a expectativa em torno da promulgação de uma Carta nova, democrática e justa, compunha o pensamento de uma parcela significativa de mulheres, desde as mais cultas e politizadas, até as mais simples e menos letradas.

Em março de 1988, uma manchete da mesma revista intitulada "Do Pacto Social ao Impasse" parece começar a dar o tom do discurso que aqui convencionamos chamar de conservador.

A matéria foi robusta. Publicada em oito páginas, mesclavam-se fotos de operários e de políticos influentes como Ulysses Guimarães com caixas de texto destacando os "novos" direitos sociais. Segundo esta matéria, uma possível disputa política entre os partidos de direita e esquerda e a ameaça do fim do mandato do então Presidente José Sarney estariam ofuscando os "juízos" dos constituintes e provocando um ganho ao trabalhador, por meio da aprovação de um pacote social irresponsável.

A notícia traz o anúncio de que a licença-maternidade passaria a ser de 120 dias e que o pai passaria a ter uma licença de 8 dias após o parto de seu filho. Além disso, todos os outros direitos foram elencados e depois comentados, como a jornada de 44 horas semanas, a multa de $40 \%$ sobre o FGTS em caso de dispensa sem justa causa, o acréscimo de $1 / 3$ nas férias, o aumento do adicional de horas extras e a concessão de $13^{\circ}$ aos aposentados.

Para esta corrente pensante, o documento era de proporções históricas e o que os parlamentares estavam fazendo era engordar a cesta de recompensas aos assalariados ${ }^{36}$. Observa-se um tom debochado nas expressões "engordar a cesta" e "recompensas".

\footnotetext{
${ }^{34}$ Edição da Revista Veja de 03 de junho de 1987, p. 32.

${ }^{35}$ A deputada Eunice Michiles se tornou, em 1979, a primeira mulher a sentar-se no Senado Federal.

${ }^{36}$ Edição da Revista Veja de 02 de março de 1988, p. 20.
} 
Ainda neste artigo de críticas, o mais alarmante é a condução do texto para o tema licença-paternidade. O trecho relevante é o seguinte:

“A novidade mais recente, aí, é a licença-paternidade de oito dias, desconhecida na maior parte dos paises, desenvolvidos ou não, e aprovada numa atmosfera de assembléia estudantil, que teve início com gargalhadas em plenário e encerrou-se com lágrimas escorrendo pelo rosto de ser defensor, o deputado Alceni Guerra. 'Sou pediatra e reconheço o drama de muitos pais que querem acompanhar suas mulheres depois do nascimento de seus filhos e não podem fazê-lo', afirma Alceni. O espanto, fora do Congresso, foi imediato. 'O dispositivo a favor dos pais, de fato, é cômico', afirmou o ministro Antonio Carlos Magalhães, das Comunicações. "’37

O descrito dispensa comentários. Importante é perceber a imprecisão da informação de que a licença-paternidade era desconhecida de muitos países.

Segundo se sabe, nos países nórdicos, uma Lei de 1987 já estendia licença de 24 semanas ao pai, após o parto da companheira. Antes disso, a Suécia, em 1976 já havia concedido a licença chamada parental, extensiva ao pai ou à mãe. A Itália, em 1977 e a França em 1984 também asseguraram a licença parental, influenciados pela nova política de ação internacional que marcou o período de transição entre o pátrio poder e poder parental, que objetivou tornar o pai cada vez mais participante das responsabilidades familiares e, em consequência, impedir que recaíssem exclusivamente sobre as mães os cuidados e a educação dos filhos ${ }^{38}$.

Mas o ponto alto da crítica é dirigido ao problema chamado elevação de custos às empresas. A afirmação foi que os benefícios sociais, principalmente licença-maternidade e multa na dispensa, então mais pesados, produziriam mais desemprego, conforme afirmou o deputado Delfim Neto. Para o empresário gaúcho Jorge Gerdau, então presidente do Grupo Gerdau, a concessão destes direitos seria uma intervenção profundamente burra as relações de trabalho ${ }^{39}$.

$\mathrm{O}$ artigo em comento repercutiu na opinião pública. A exemplo disso, uma leitora de Brasília/DF, escreveu para a Veja, que publicou seu comentário na sessão Cartas. Segundo esta leitora, a mesma se declarava apreensiva com a concessão de licença-

\footnotetext{
${ }^{37}$ Edição da Revista Veja de 02 de março de 1988, p. 22.

${ }^{38}$ Cf. BARROS, Alice Monteiro de. A mulher e o direito do trabalho. São Paulo: LTr, 1995.

${ }^{39}$ Edição da Revista Veja de 02 de março de 1988, p. 24.
} 
maternidade de 120 dias: "(...) meu medo é que com essa medida a mulher fique mais discriminada no ambiente de trabalho; se já era difícil a contratação de uma mulher antes, agora então será pior" 40 .

Nesta toada, edições seguintes, outro artigo é publicado, desta vez por uma mulher, na sessão Ponto de Vista da mesma revista e intitulado "Uma Falsa Conquista".

Em suma, o artigo afirma categoricamente que os 120 dias de licença-maternidade aumentariam o desemprego da mão-de-obra feminina. A autora afirma que a mulher, principalmente mais jovem seria preterida no emprego, se o empregador seguisse o raciocínio simplista de que ela poderia engravidar por até três anos seguidos, gozando todas as licenças requeridas e ainda iria fazer jus às três férias do período.

A autora, indo além, monta um raciocínio às avessas quanto à proteção à maternidade e distorce o perfil da mulher de classe média. Ela declarou:

“A licença ampliada, com certeza, privilegiará, sobretudo, as mulheres das classes mais abastadas, que seguramente não passarão 120 dias só cuidando do recém-nascido porque têm dinheiro para pagar creche, babás, cozinheira. Ficarão, na verdade, com maior tempo para se dedicar à ginástica estética, por exemplo. Mas também não conseguirão preencher toda a licença à custa de exercícios. Afinal, para a mulher que ocupa cargo executivo é mais interessante voltar ao trabalho num prazo menor, principalmente aquelas que possuem beneficios como comissões e diárias. Em contrapartida, a mulher operária, de periferia, sem instrução, acabará sendo duramente atingida pelo desemprego"41.

Estranha colocação!

Encerrando a pesquisa nesta revista específica, interessante examinar notícia publicada após a promulgação da Constituição, intitulada “Em Nome da Lei-as empresas fazem adaptações e seguem à risca os direitos trabalhistas assegurados pela Constituição". Em resumo, a publicação, que traz na página principal a foto de um casal de trabalhadores que acabara de ter gêmeos, comenta dificuldades para algumas e nem tanto para outras empresas em assegurar os novos direitos.

Enquanto o empresário André Beer, então presidente da Associação Nacional dos Fabricantes de Veículos Automotores reclamou em público da onerosidade da nova Carta,

\footnotetext{
${ }^{40}$ Edição da Revista Veja de 30 de março de 1988, p. 15.

${ }^{41}$ A autora deste artigo é Maria Rosineide Bentes, à época, advogada e presidente da Associação da Mulher Paraense.
} 
ao mesmo tempo planejou discurso crítico para a inauguração do Salão do Automóvel de São Paulo de 1988. O presidente José Sarney, que havia confirmado sua presença, cancelou o compromisso às pressas. Mesmo assim, entre outras declarações, o mesmo empresário reafirmou que os benefícios trabalhistas implicariam aumento substancial nas folhas de pagamento.

A contrário sensu, a direção da empresa multinacional Volvo declarou, no mesmo artigo, que o impacto sobre sua folha de pagamento na fábrica do Paraná seria elevada em apenas $5 \%^{42}$.

Na mesma época, no dia 05 de outubro de 1988, o jornal Folha de S. Paulo publicou matéria de capa noticiando a promulgação da Constituição Cidadã. Entre nuances variadas, trouxe artigo mais crítico, intitulado Constituição, Empresários e Trabalhadores, assinado por um de seus colunistas, Rodolpho Bertolla. O conteúdo critica severamente a Carta quanto ao número de artigos e quanto aos direitos sociais, incluindo licençamaternidade, que, segundo o autor, deveria estar ao encargo exclusivo da negociação coletiva.

Na mesma data, o jornal O Estado de São Paulo publica diversas notícias sobre a nova ordem democrática e num tom mais neutro, estampa em primeira página: Começa a Nova Ordem Constitucional.

No mesmo jornal, em artigo da edição de 8 de outubro, o então ministro do TST, Marcelo Pimentel, tece comentários a respeito da auto-aplicabilidade da licençamaternidade. Para ele, alguma demora em elaboração de legislação previdenciária complementar poderia retardar a aplicação do direito.

Os jornais da CUT (Central Única dos Trabalhadores) analisados no mesmo período revelam o apoio da entidade sindical aos direitos relativos à mulher, em especial à proteção à maternidade. A publicação Cadernos da CUT de setembro de 1988 traz a foto emblemática, reproduzida abaixo, em que as manifestantes se uniram em ato conjunto do movimento de mulheres e do movimento sindical, pela licença-maternidade de 120 dias e paternidade de 8 dias, frente ao prédio do Centro das Indústrias do Estado de São Paulo.

\footnotetext{
${ }^{42}$ Edição da Revista Veja de 19 de outubro de 1988, p. 109.
} 


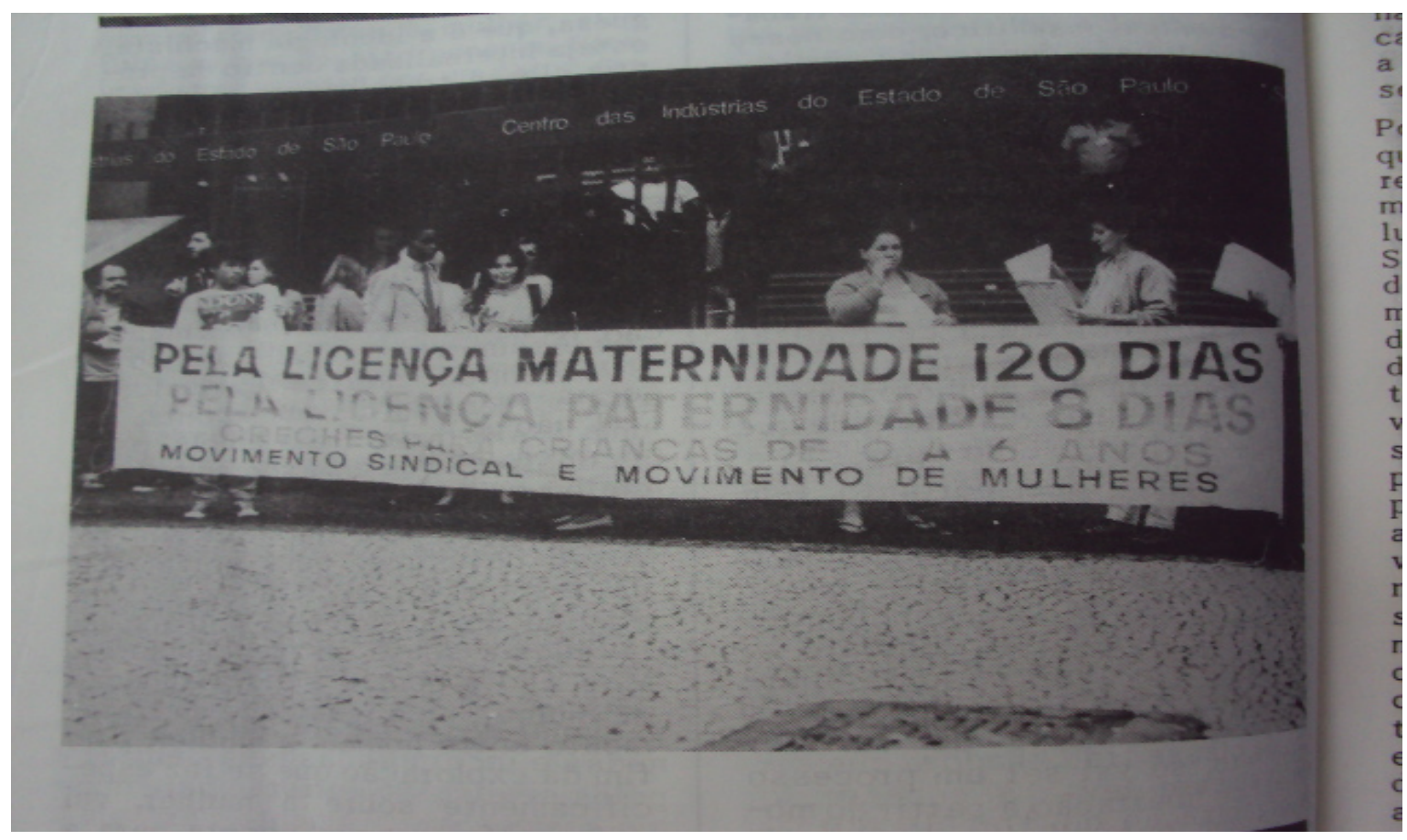

Assim, as diversas publicações de trabalhadores e do movimento sindical demonstram a identificação destes com os direitos que compunham a sessão dos direitos sociais. Em especial, o movimento de mulheres e o movimento sindical, assim como manifestações de estudiosos da matéria, confiavam que aquele seria o momento histórico e decisivo para a transformação das relações de trabalho.

Comemora-se, ainda hoje, a proteção à maternidade trazida pela ampliação da licença na Constituição Federal. É importante mencionar que, ao mesmo tempo, as mulheres tiveram reconhecidos outros direitos essenciais, por meio de avanços tais como a igualdade jurídica entre homens e mulheres, a igualdade de direitos e responsabilidades na família, a eliminação do pátrio poder, entre outros ${ }^{43}$.

${ }^{43}$ ABRAMO, Laís. A Constituição de 1988 e o mundo do trabalho no Brasil, in: KREIN, José Dari; SANTANA, Marco Aurélio; BIAVASCHI, Magda (orgs.). Vinte anos da Constituição cidadã no Brasil, 2010. 


\subsection{Negação do mito: o crescimento do emprego formal feminino}

O cenário desenhado pelos discursos da classe empresária e seus representantes ao longo da Assembléia Constituinte não se confirmou. Para que se possa proceder a uma melhor análise dos desdobramentos econômicos sob o aspecto da empregabilidade da mulher, nos anos que sucederam 1988, avaliaremos a evolução do emprego feminino, desmistificando crenças que não só partiam de um lobby dos grandes capitalistas, mas até mesmo de mulheres e homens estudiosos do mercado de trabalho, conforme se verificou na seção anterior.

Antes de tudo, convém esclarecer que, ao longo da década de 1980, vinha aumentando a taxa de participação feminina no mercado de trabalho brasileiro. Contudo, a forma de inserção das mulheres era, de um modo geral, mais precária que a dos homens. Por exemplo, no que diz respeito à formalização da relação de emprego, a porcentagem de mulheres com carteira de trabalho assinada era muito menor do que a dos homens. Além disso, o salário pago às mulheres, em média, era bem inferior ao dos homens ${ }^{44}$.

Em dezembro de 1988, de acordo com a RAIS ${ }^{45}$, cerca de um terço $(33,9 \%)$ dos empregos formais no Brasil eram ocupados por mulheres e dois terços $(66,1 \%)$ por homens. Se o aumento do período de licença-maternidade desestimulasse as empresas a contratar mulheres para o seu quadro de funcionários, a proporção de mulheres com emprego formal deveria ter se reduzido. Porém, não foi isso que aconteceu nos anos seguintes: a porcentagem de mulheres no total dos empregados registrados elevou-se para 35,9\% em 1992 e continuou aumentando gradualmente ao longo da década de 1990 (Tabela 1).

${ }^{44}$ Cf. HOFFMAN, Rodolfo; LEONE, Eugenia T. Participação da mulher no mercado de trabalho e desigualdade da renda domiciliar per capita no Brasil: 1981-2002, Nova Economia, Belo Horizonte, vol. 14, n. 2, maio/ago. 2004.

45 A Relação Anual de Informação Social (RAIS) é um cadastro do Ministério do Trabalho e Emprego que permite mensurar o emprego com carteira de trabalho assinada e o emprego em regime estatutário nos estabelecimentos credenciados. Não são computados os trabalhadores domésticos com carteira assinada, nem os estagiários. 
Tabela 1

Distribuição (\%) do Número de Empregos Formais por Gênero Brasil: 1985-2009

\begin{tabular}{|c|c|c|c|}
\hline Ano & Masculino & Feminino & Total \\
\hline 1985 & 67,6 & 32,4 & 100,0 \\
\hline 1986 & 66,9 & 33,1 & 100,0 \\
\hline 1987 & 66,4 & 33,6 & 100,0 \\
\hline 1988 & 66,1 & 33,9 & 100,0 \\
\hline 1989 & 65,7 & 34,3 & 100,0 \\
\hline 1990 & 64,7 & 35,3 & 100,0 \\
\hline 1991 & 64,5 & 35,5 & 100,0 \\
\hline 1992 & 64,1 & 35,9 & 100,0 \\
\hline 1993 & 63,6 & 36,4 & 100,0 \\
\hline 1994 & 63,1 & 36,9 & 100,0 \\
\hline 1995 & 62,6 & 37,4 & 100,0 \\
\hline 1996 & 62,2 & 37,8 & 100,0 \\
\hline 1997 & 62,1 & 37,9 & 100,0 \\
\hline 1998 & 61,6 & 38,4 & 100,0 \\
\hline 1999 & 60,9 & 39,1 & 100,0 \\
\hline 2000 & 60,9 & 39,1 & 100,0 \\
\hline 2001 & 60,5 & 39,5 & 100,0 \\
\hline 2002 & 60,2 & 39,8 & 100,0 \\
\hline 2003 & 60,0 & 40,0 & 100,0 \\
\hline 2004 & 60,0 & 40,0 & 100,0 \\
\hline 2005 & 59,7 & 40,3 & 100,0 \\
\hline 2006 & 59,4 & 40,6 & 100,0 \\
\hline 2007 & 59,2 & 40,8 & 100,0 \\
\hline 2008 & 58,9 & 41,1 & 100,0 \\
\hline 2009 & 58,6 & 41,4 & 100,0 \\
\hline
\end{tabular}

Fonte: MTE-RAIS

O Gráfico 1 permite comparar o ritmo de crescimento do número de empregos formais ocupados por homens e por mulheres. Embora a recessão econômica verificada no Governo Collor tenha causado uma redução no número de empregados com registro formalizado no País, nota-se claramente que as mulheres foram relativamente menos afetadas que os homens; e que a contratação de mulheres volta a crescer mais rapidamente após 1992. 


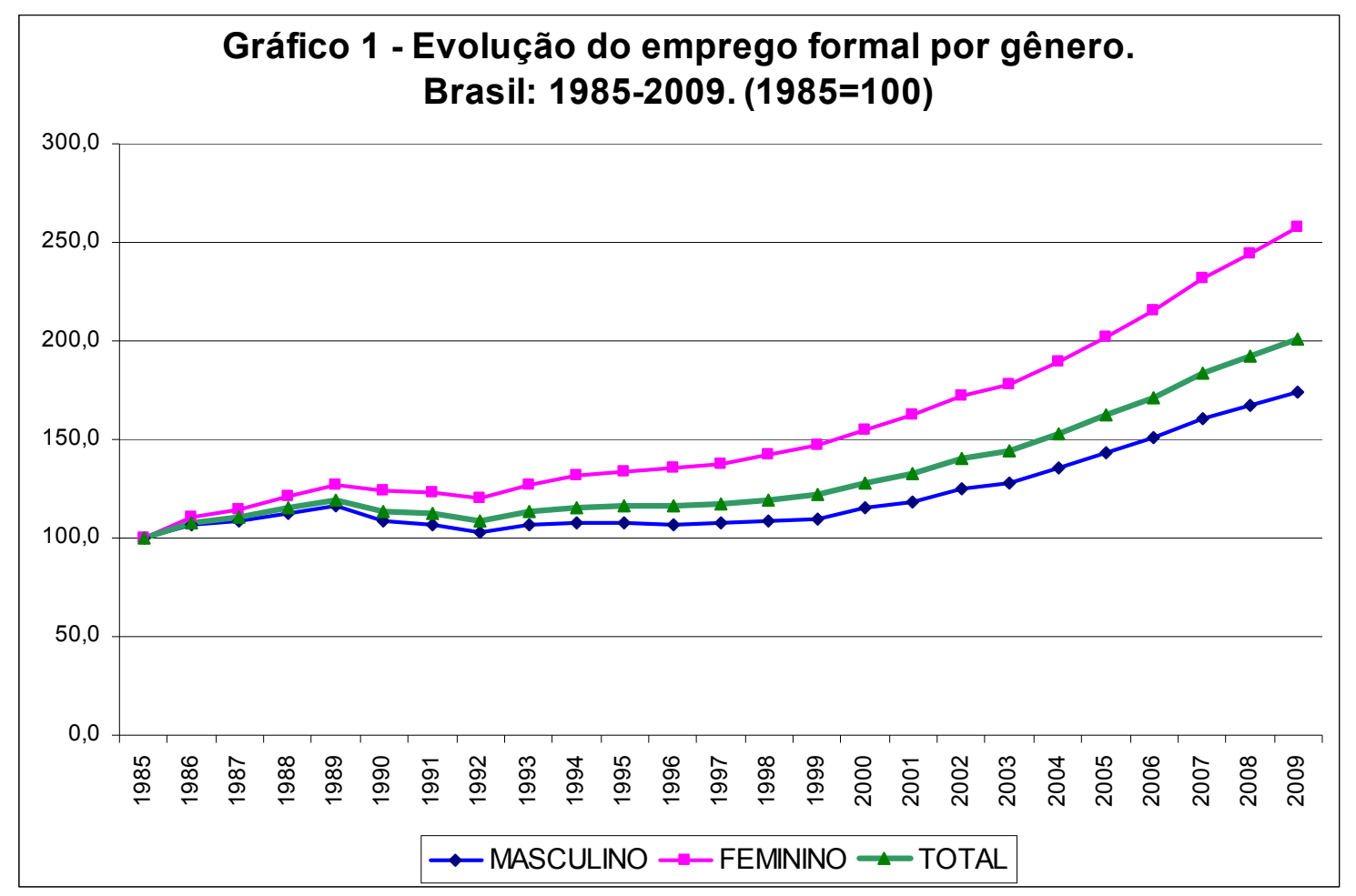

A maioria dos empregos formais ocupados por mulheres encontra-se no Setor Terciário. Em dezembro de 1988, de acordo com a RAIS, cerca de 33,5\% das mulheres que tinham o vínculo de emprego registrado trabalhavam na administração pública, outros 29,5\% em atividades de serviços, 19\% na indústria de transformação e 12,5\% no comércio. Em dezembro de 1995, essas porcentagens correspondiam a 34\%, 33,5\%, 15\% e 13\%, respectivamente. Ou seja, houve um aumento significativo na participação de mulheres registradas em atividades de serviços e uma redução proporcional na indústria de transformação. Tendência semelhante foi observada entre os homens, uma vez que o emprego industrial esteve em queda durante a década de 1990.

É importante apontar, também, que as mulheres aumentaram sua participação no total do emprego formal em todos os setores de atividade econômica, entre 1988 e 1992 (Tabela 2). Ou seja, o argumento de que as empresas contratariam um número menor de mulheres por causa da alteração na legislação referente à licença-maternidade não se aplica a nenhum setor relevante. Note-se, também, que os homens continuaram sendo maioria em todas as atividades econômicas, com exceção da administração pública, onde a 
porcentagem feminina era de 52,6\% em dezembro de 1988 e aumentou para $54,9 \%$ em 1992 e para 55,5\% em 1995.

Tabela 2

Participação (\%) de Homens e Mulheres no Total dos Empregos Formais por Setor de Atividade Econômica

Brasil: 1988, 1992, 1995

\begin{tabular}{lcccccc}
\hline \multirow{2}{*}{ Setor de Atividade } & \multicolumn{2}{c}{ 1988 } & \multicolumn{2}{c}{1992} & \multicolumn{2}{c}{1995} \\
\cline { 2 - 7 } & Homem & Mulher & Homem & Mulher & Homem & Mulher \\
\hline Agropecuária & 85,8 & 14,2 & 85,6 & 14,4 & 86,7 & 13,3 \\
Extrativa mineral & 93,4 & 6,6 & 92,8 & 7,2 & 92,9 & 7,1 \\
Indústria de transformação & 73,8 & 26,2 & 73,5 & 26,5 & 73,2 & 26,8 \\
Serviços utilidade pública & 85,8 & 14,2 & 85,2 & 14,8 & 83,6 & 16,4 \\
Construção civil & 93,8 & 6,2 & 91,9 & 8,1 & 92,9 & 7,1 \\
Comércio & 66,5 & 33,5 & 66,0 & 34,0 & 64,7 & 35,3 \\
Serviços & 65,1 & 34,9 & 63,2 & 36,8 & 58,9 & 41,1 \\
Administração pública & 47,4 & 52,6 & 45,1 & 54,9 & 44,5 & 55,5 \\
\hline Total ${ }^{(1)}$ & 66,1 & 33,9 & 64,1 & 35,9 & 62,6 & 37,4 \\
\hline
\end{tabular}

Fonte: MTE-RAIS

Nota: ${ }^{(1)}$ inclui "outro/ignorado"

Tabela 3

Evolução do Emprego Formal por Gênero $(1988$ = 100)

Brasil: 1988-1992

\begin{tabular}{|c|c|c|c|c|c|c|}
\hline Grande Grupo Ocupacional & Gênero & 1988 & 1989 & 1990 & 1991 & 1992 \\
\hline \multirow{2}{*}{$\begin{array}{l}\text { Membros superiores do poder público, } \\
\text { dirigentes e gerentes }\end{array}$} & Masculino & 100,0 & 100,6 & 100,5 & 102,3 & 113,6 \\
\hline & Feminino & 100,0 & 102,4 & 101,9 & 113,7 & 115,9 \\
\hline \multirow{2}{*}{ Profissionais das ciências e das artes } & Masculino & 100,0 & 103,5 & 101,1 & 99,1 & 93,3 \\
\hline & Feminino & 100,0 & 102,4 & 105,1 & 104,6 & 109,6 \\
\hline \multirow{2}{*}{$\begin{array}{l}\text { Trabalhadores agropecuários, florestais e da } \\
\text { pesca }\end{array}$} & Masculino & 100,0 & 115,2 & 116,9 & 116,6 & 122,1 \\
\hline & Feminino & 100,0 & 123,7 & 113,3 & 108,6 & 112,1 \\
\hline \multirow{2}{*}{ Trabalhadores da produção de bens industriais } & Masculino & 100,0 & 102,3 & 93,3 & 91,0 & 85,9 \\
\hline & Feminino & 100,0 & 110,1 & 104,3 & 98,2 & 91,1 \\
\hline \multirow{2}{*}{ Trabalhadores de serviços administrativos } & Masculino & 100,0 & 99,7 & 92,6 & 92,3 & 95,7 \\
\hline & Feminino & 100,0 & 101,0 & 99,0 & 99,3 & 104,0 \\
\hline \multirow{2}{*}{ Trabalhadores do comércio } & Masculino & 100,0 & 105,6 & 103,8 & 100,9 & 98,8 \\
\hline & Feminino & 100,0 & 108,4 & 107,1 & 104,5 & 102,3 \\
\hline \multirow{2}{*}{ Trabalhadores dos serviços } & Masculino & 100,0 & 103,8 & 102,9 & 106,2 & 106,7 \\
\hline & Feminino & 100,0 & 103,8 & 103,1 & 107,3 & 105,8 \\
\hline \multirow{2}{*}{ TOTAL } & Masculino & 100,0 & 102,9 & 95,9 & 94,9 & 91,3 \\
\hline & Feminino & 100,0 & 104,6 & 102,2 & 101,8 & 99,6 \\
\hline
\end{tabular}

Fonte: MTE-RAIS 
Outra informação relevante diz respeito à evolução do emprego formal por grande grupo ocupacional (Tabela 3). Comparando homens e mulheres, pode-se constatar que, nos anos posteriores ao aumento da licença-maternidade, o desempenho feminino foi superior entre os membros superiores do poder público, dirigentes e gerentes, entre os profissionais das ciências e das artes, entre os trabalhadores da produção industrial, entre os trabalhadores de serviços administrativos e entre os trabalhadores do comércio. Também se pode notar que, no conjunto dos empregos formais, o número total de empregos ocupados por mulheres cresceu relativamente mais do que o dos homens, em 1989, inclusive em ocupações que exigem maior qualificação.

Uma das explicações para o crescimento da participação das mulheres no total dos empregos formais é o fato do seu salário médio ser menor do que o dos homens. Na Tabela 4, pode-se observar que o salário médio das mulheres brasileiras em dezembro de 1988 representava dois terços $(66,4 \%)$ do salário médio dos homens. Embora essa proporção tenha se elevado um pouco nos anos seguintes, em 1992 as mulheres ainda tinham uma remuneração média cerca de $30 \%$ menor do que a dos homens ${ }^{46}$.

\section{Tabela 4}

Proporção (\%) da remuneração média das mulheres em comparação com a dos homens Brasil: 1988-1992

\begin{tabular}{lccccc}
\hline Grande Grupo Ocupacional & $\mathbf{1 9 8 8}$ & $\mathbf{1 9 8 9}$ & $\mathbf{1 9 9 0}$ & $\mathbf{1 9 9 1}$ & $\mathbf{1 9 9 2}$ \\
\hline Profissionais das ciências e das artes & 53,0 & 57,1 & 65,0 & 56,5 & 59,1 \\
Membros super. poder público, dirigentes e gerentes & 32,6 & 26,9 & 30,6 & 27,8 & 41,0 \\
Trabalhadores de serviços administrativos & 71,8 & 73,2 & 72,5 & 74,5 & 74,7 \\
Trabalhadores do comércio & 56,6 & 58,6 & 61,5 & 60,9 & 61,4 \\
Trabalhadores dos serviços & 66,4 & 71,5 & 67,6 & 66,6 & 66,2 \\
Trabalhadores agropecuários, florestais e da pesca & 74,9 & 76,1 & 77,4 & 78,0 & 84,0 \\
Trabalhadores da produção de bens industriais & 58,9 & 60,4 & 59,5 & 61,1 & 58,7 \\
\hline TOTAL & 66,4 & 70,0 & 73,5 & 67,7 & 69,9 \\
\hline
\end{tabular}

Fonte: MTE-RAIS

Portanto, o pequeno custo adicional representado pelo aumento da licençamaternidade (quatro meses de salário, quando necessária a contratação de outro empregado para substituí-la) não inibiu as empresas de continuarem contratando mulheres e de registrarem o vínculo de emprego.

Esta conclusão é reforçada por um estudo produzido pela OIT em cinco países da América Latina (Argentina, Brasil, Chile, México e Uruguai), que analisou os custos de

\footnotetext{
${ }^{46}$ Essa desproporção vem se reduzindo. Em dezembro de 2009, a remuneração média das mulheres correspondia a aproximadamente $83 \%$ da remuneração média dos homens, de acordo com a RAIS.
} 
contratação de assalariados de ambos sexos, excluindo o serviço doméstico, contemplando: licença-maternidade, custo de substituição, creche e direito à amamentação. Os resultados da pesquisa indicaram que os custos monetários para o empregador relacionados à contratação das mulheres são muito reduzidos. No Brasil, o número total de licenças maternidade concedidas em 1999 correspondia a apenas 3,0\% do total das trabalhadoras assalariadas no setor privado (excluindo o serviço domestico); e os benefícios monetários recebidos pelas trabalhadoras assalariadas durante a licença-maternidade representavam apenas $1,7 \%$ da massa salarial feminina registrada ${ }^{47}$.

A pesquisa da OIT refuta de forma indubitável o argumento dominante de que é mais caro empregar uma mulher devido aos custos indiretos associados à sua contratação, em particular aos dispositivos legais de proteção à maternidade e ao cuidado infantil. $\mathrm{O}$ mesmo vale para supostos problemas relacionados às responsabilidades familiares, que continuam sendo assumidas principalmente pelas mulheres, considerados também fatores adicionais de custos. A principal razão para que estes custos sejam tão reduzidos está situada no âmbito da legislação trabalhista e das políticas públicas: os benefícios médicos e monetários associados à maternidade não são financiados diretamente pelo empregador que decide contratar uma mulher, mas sim por fundos públicos ou pelos sistemas de seguridade social. Além disso, as contribuições dos empregadores para esses sistemas não estão relacionados ao sexo (nem à idade) dos trabalhadores contratados. Portanto, em relação aos aspectos mencionados, a contratação de uma mulher representa um custo adicional nulo para os empregadores. A ideia de que a proteção à maternidade é um "risco" muito elevado para os empregadores pode ser considerada como uma falácia.

Em suma, pode-se afirmar, com alguma segurança, que aquele argumento de que as empresas contratariam um número menor de mulheres em decorrência da alteração na legislação referente à licença-maternidade não passava de um "mito"48. Os impactos posteriores não foram negativos para as taxas de empregabilidade da mulher, embora as mesmas tenham assumido postos com salários inferiores.

${ }^{47}$ Cf. ABRAMO, Laís; TODARO, Rosalba. Custos do trabalho de homens e mulheres na América Latina. In: COSTA, Albertina et al. (orgs.). Mercado de trabalho e gênero: comparações internacionais. Rio de Janeiro: FGV, 2008. p. 141-158.

${ }^{48}$ Os "mitos" são ideias difundidas pelo pensamento hegemônico "[...] a partir de uma constante propaganda pelos diferentes governos e da recorrente reprodução, sem grande contestação, pelos meios de comunicação de massa e até por certos setores mais progressistas. [...] demonstraram ser ideias falsas, sem correspondência na realidade nacional.” POCHMANN, Marcio. A década dos mitos. São Paulo: Contexto, 2001, p. 7. 


\section{CAPÍTULO 3}

\section{A POSIÇÃO DA OIT SOBRE PONTOS RELEVANTES DA PROTEÇÃO À MATERNIDADE}

"Uma coisa é um direito; outra, a promessa de um direito futuro. Uma coisa é um direito atual; outra, um direito potencial. Uma coisa é ter um direito que é, enquanto reconhecido e protegido; outra é ter um direito que deve ser, mas que, para ser, ou para que passe do dever ser ao ser, precisa transformar-se, de objeto de discussão de uma assembléia de especialistas, em objeto de decisão de um órgão legislativo dotado de poder de coerção." ${ }^{49}$

Como bem explica Norberto Bobbio, em $A$ era dos direitos, todo processo de afirmação e consolidação de direitos sociais ocorre em arenas políticas, geralmente envolve interesses econômicos e está permeado por relações de poder e por crenças compartilhadas. No caso da proteção à maternidade, não poderia ser diferente, como ficou claro no capítulo anterior.

O presente capítulo procura apontar a influência das Convenções Internacionais na difusão de um padrão mínimo de proteção e reforçar o argumento sobre a diversidade de sistemas existentes no mundo contemporâneo, pois a forma e o conteúdo da proteção à maternidade em cada nação, sem dúvida, são produtos de fenômenos historicamente definidos. Também se pretende confrontar a legislação brasileira em vigor com as Convenções Internacionais. Por fim, procura apresentar a posição atual da OIT em relação aos desafios para fazer avançar os sistemas nacionais de proteção à maternidade.

${ }^{49}$ BOBBIO, Norberto. A era dos direitos, 2004, p. 77 


\subsection{Convenções internacionais referentes à licença-maternidade}

Um importante aspecto a ser analisado por ora são os entendimentos firmados em Convenções Internacionais a respeito da proteção à maternidade, em especial no que diz respeito à licença.

A incorporação da mulher no mercado de trabalho e a modificação de sua imagem na sociedade contribuíram para que se alterasse também o seu comportamento no emprego e na profissão, lutando por um tratamento igual do dispensado aos homens. Reconhecida esta igualdade formal, houve a necessidade de uma revisão de uma série de medidas de tutela no plano internacional, que inspirou as legislações internas dos países.

Entretanto, se o papel da mulher na sociedade modificou-se, a sua função fisiológica de procriação não se alterou, apesar das técnicas já citadas de inseminação artificial, justificando as medidas de tutela e seu aperfeiçoamento.

Durante a gestação, a mulher não se limita a aguardar o filho; trata-se de um processo psicológico complexo, de intensa atividade emocional, que testa tanto suas reservas físicas quanto psíquicas como sua aptidão para criar uma nova vida. Todo esse processo implica uma situação de estresse, capaz de gerar transtornos físicos e alterações psiquiátricas.

Reconhecendo que a participação das mulheres, inclusive as casadas, na força de trabalho é uma realidade incontestável, as primeiras medidas tomadas pelos organismos internacionais visaram proteger a gravidez e a maternidade ${ }^{50}$.

A primeira Convenção sobre a matéria foi a de $n^{0} 3$, ratificada por alguns países como Alemanha, Argentina, Brasil, Chile, França, Hungria, Espanha dentre vários outros, sendo que posteriormente, Brasil e Uruguai a denunciaram.

A matéria versada era a licença remunerada compulsória de seis semanas antes e seis após o parto, além dos intervalos para aleitamento. Sua aplicação era dirigida à empregadas da indústria e comércio, sendo que apenas em 1921 a Recomendação $n^{0} 12$ da OIT estendeu o mesmo benefícios às empregadas rurais.

Em face de discrepâncias e desarmonias de legislações nacionais com a Convenção $\mathrm{n}^{\mathrm{o}}$ 3, a mesma foi revisada, com base em sugestões enviadas pelos países membros da OIT. Foram elas: maior flexibilidade na distribuição do período de licença antes e após o parto,

\footnotetext{
${ }^{50}$ Cf. BARROS, Alice Monteiro de. A mulher e o direito do trabalho. São Paulo: LTr, 1995.
} 
ampliação da abrangência para todas as trabalhadoras e retribuição da licença-maternidade por um sistema público de saúde, porém, não a cargo do empregador.

Para embasar com maior segurança a revisão de tão importante Convenção, foi ouvida, também a OMS (Organização Mundial de Saúde), que entendeu necessária recomendação de tratamento específico para a empregada gestante, visando sua proteção, sendo as principais a licença obrigatória de duas semanas antes do parto, um descanso obrigatório pós-parto de, pelo menos, seis semanas, podendo prolongar-se por mais quatro, dada a importância do período para a mãe e para o bebê. Ainda foi recomendada elasticidade no trato das paradas para amamentação, com intervalos diários e não inferiores à uma hora e meia.

Diante deste processo de mudança, a Convenção $n^{\circ} 3$ foi revista pela $n^{\circ} 103 \mathrm{em}$ 1952, sendo ratificada por alguns países ${ }^{51}$ e vigorando a partir de 1955, com alterações extremamente importantes, ou seja, ampliando o campo de aplicação das normas de tutela à maternidade também às trabalhadoras rurais, domésticas e que trabalham em domicílio, mantendo o mesmo período de duração da licença anterior, nunca inferior a seis semanas, mas em conformidade com a legislação de cada estado-membro.

De uma forma geral, entende-se como positiva a revisão ocorrida, pois englobou em seu conteúdo outras proteções, como licença integral em caso de parto prematuro e assistência médica durante todo o período gestacional e no pós-parto. Esta Convenção foi ratificada pelo Brasil em 18 de junho de $1965^{52}$.

Importante analisar a influência das normas internacionais nas internas e sua decisiva importância para a garantia da proteção ao direito que atine às diversas situações da maternidade. Pode-se afirmar, diante do exposto, que a influência das Convenções 3 e 103 da OIT na ordem internacional fez-se realidade para a aplicação da norma quanto à obrigatoriedade, duração e distribuição da licença-maternidade ou médica, na sua prorrogação e na impossibilidade de despedida durante este processo. Também os entendimentos dos diversos tribunais estrangeiros, como o próprio TST, firmaram a proibição de dispensa da mulher grávida, a duração dos intervalos para amamentação e o deslocamento do pagamento do salário-maternidade para o seguro social.

51 Áustria, Azerbaidjão, Brasil, Bolívia, Cuba, Equador, Eslovênia, Espanha, Gana, Grécia, Guatemala, Guiné-Equatorial, Hungria, Itália, Iugoslávia, Líbia, Luxemburgo, Mongólia, Países Baixos, Polônia, Portugal, Alemanha, Rússia, Ucrânia, Uruguai, Venezuela, Zâmbia.

${ }^{52}$ Cf. MARTINS, Sergio Pinto. Convenções da OIT. São Paulo: Atlas, 2009. 
Conclui-se, assim, que razões econômicas e sociais influem na questão da proteção à maternidade e contribuem para que o aperfeiçoamento da tutela seja um tema sempre atual. $\mathrm{O}$ aperfeiçoamento da tutela no nível internacional e a expansão das garantias em nível constitucional ou negocial em cada país (a despeito das tratativas individuais do contrato de trabalho) indicam um ganho real na eficácia da proteção.

Especificamente no Brasil, é notória a influência das normas internacionais de proteção à maternidade. Com a promulgação da CLT em 1943, determinou-se, no art. 393, que caberia ao empregador o pagamento dos salários integrais durante as seis semanas anteriores e posteriores ao parto, com base na Constituição de 1937, mas que afrontava o conteúdo da Convenção n.3.

Com a revisão já citada, e sua conseqüente ratificação pelo Brasil, assumimos a responsabilidade de transferir este ônus para os cofres públicos, o que se confirmou formalmente com a ratificação da Convenção n. 118, em 1962, e de fato em 1974 com a criação da Lei 6.136 daquele ano.

Com a comemorada Constituição de 1988, a licença-maternidade foi ampliada para 120 dias, conforme já explicitado, provocando a manifestação da doutrina a respeito da autoexecutoriedade da norma. Felizmente, segundo nos revela a própria história jurídica nacional, a corrente majoritária entendeu que o dispositivo não dependia de regulamentação por lei ordinária, porque a licença deveria ser concedida pelo empregador sem prejuízo do emprego e do salário, mediante reembolso pelo órgão previdenciário. Explica-se: o direito em debate integra o rol dos direitos sociais do trabalhador sob proteção constitucional do art. $7^{\circ}$, XVIII, da Constituição. Deve, portanto, ser concedido pelo empregador sem prejuízo do salário e do emprego, sendo sua observância imediata, uma vez que estabelece relação jurídica diretamente entre empregado e empregador, devendo este ser reembolsado pelo órgão previdenciário, formando-se assim relação jurídica previdenciária entre empregador e órgão público, à parte dos interesses do empregado $^{53}$.

Não é pequena, mas grande e decisiva a mobilização internacional e seus reflexos nos diversos países. Deve-se a esta mobilização a mínima equalização de entendimentos e normas a respeito da proteção à maternidade. No entanto, poucos avanços foram obtidos

\footnotetext{
${ }^{53}$ Conforme entendimento jurisprudencial, a exemplo do RR-61061/92.2-Ac $3^{\mathrm{a}}$ Turma T. da $3^{\mathrm{a}}$ Região.
} 
neste cenário após 1988 em relação às Convenções Internacionais, propriamente ditas. Nada novo foi ratificado pelo Brasil, por exemplo, que ampliasse a participação do pai na licença-maternidade, com extensão de seu afastamento. Nada se firmou também em relação aos direitos de conciliação entre trabalho e família.

Formalmente, houve um avanço significativo no plano das normas internacionais no sentido de propiciar ampliação da proteção foi a Convenção 183 da OIT, de maio de 2000. Esta norma recomenda que os estados membros procurem oferecer pelo menos 14 semanas de licença-maternidade (sendo 6 semanas compulsoriamente no pós-parto) paga pela Previdência Social (ou outra disposição legal nacional), assim como garantia de pausas para amamentação durante a jornada diária de trabalho. E prevê a possibilidade de extensão da licença em casos especiais. Não obstante oferecer um período de licença maior do que o recomendado pela OIT, o Brasil ainda não ratificou esta norma.

O texto completo da Convenção 183 da OIT está disponível no Anexo I.

\subsection{Posição atual da OIT sobre a proteção à maternidade}

Em 2009, a OIT publicou importante estudo sobre gênero e trabalho ${ }^{54}$, que traduz uma iniciativa de cunho social (no sentido de não obrigacional) e ilumina a questão atual da luta das mulheres que decidem empreender os papéis de mães e profissionais. Relatórios como este inspiram governos a criar políticas públicas relativas ao tema, como servem também de material rico para os legisladores se basearem e elaborarem legislações úteis e modernas (não aquelas que somente atendem a interesses particulares).

Com este relatório - que vale a pena ser analisado, embora não seja o objetivo deste estudo -, a OIT e o PNUD (Programa das Nações Unidas para o Desenvolvimento), buscaram contribuir para enfrentar um importante desafio de nosso tempo e citado nesta dissertação: a conciliação entre vida familiar e pessoal e a vida no trabalho.

Olhando para América Latina e Caribe, região muito marcada pela desigualdade econômica e social, o relatório argumenta que é necessário avançar para a conciliação de ambas as esferas com co-responsabilidade social, isto é, entre homens e mulheres, mas

${ }^{54}$ ORGANIZAÇÃO INTERNACIONAL DO TRABALHO. Trabalho e família: rumo a novas formas de conciliação com co-responsabilidade social. (Em associação com o Programa das Nações Unidas para o Desenvolvimento - PNUD). Brasília: OIT, 2009. 
também entre as famílias, Estados, mercados e a sociedade em geral. Importantíssima também a participação das empresas nesta transformação social.

Esta é uma dimensão fundamental para promover a igualdade e combater a pobreza a partir do trabalho. Além disso, constitui-se em um requisito indispensável para avançar na construção da equidade de gênero e para auxiliar o cumprimento das metas da Agenda Hemisférica do Trabalho Decente, lançada pela OIT em 2006, e que prevê aumentar em $10 \%$ as taxas de participação e ocupação das mulheres até 2015 e reduzir em $50 \%$, no mesmo período, as atuais desigualdades de gênero em matéria de informalidade e remuneração ${ }^{55}$.

Abordando diretamente o tema da conciliação e suas barreiras, segundo a OIT, há três fatores que fundamentam a progressiva diminuição das mulheres em cargos de maior hierarquia: a) a menor conexão da mulher com as redes (inclusive masculina) necessárias para a ascensão; b) a crença de que a mulher casada é um risco para a empresa, por suas responsabilidades familiares; c) dificuldade para conciliar as responsabilidades profissionais e familiares, comprometendo a possibilidade de mobilidade e jornadas mais longas.

Para enfrentar o problema da conciliação, as mulheres adotam diferentes estratégias, dependendo do poder aquisitivo da família. Em geral, as famílias com maior poder aquisitivo contratam apoio às atividades domésticas e ao cuidado dos filhos, por meio de empregadas domésticas, babás e mesmo enfermeiras. Assim, a mulher consegue permanecer no mercado e manter as atividades familiares sob controle.

Em muitos lares de classe média, a mulher trabalhadora conta apenas com uma faxineira que organiza o lar uma ou duas vezes por semana, restando a ela cuidar dos detalhes diários quando do retorno ao trabalho. Muitas vezes essas mulheres passam e lavam as roupas à noite, enquanto preparam o jantar e acompanham a tarefa escolar dos filhos, além de inúmeras outras responsabilidades inerentes ao grupo familiar.

No caso das famílias pobres, a mulher costuma lidar sozinha com todas estas atividades. É comum as empregadas domésticas, por exemplo, deixarem seus filhos com parentes ou vizinhos, ou mesmo deixar os filhos mais novos aos cuidados da filha mais velha para poderem trabalhar e sustentar o lar. O acúmulo de jornadas e a impossibilidade

55 Para maiores explanações sobre o tema Trabalho Decente, cf. ROCHA, Thaíssa Tamarindo da. Promoção do trabalho decente no limiar do século XXI: velhos obstáculos, novos paradigmas. Campinas: Unicamp.IE, 2007 (Monografia); e PRONI, Marcelo W.; ROCHA, Thaíssa Tamarindo da. A OIT e a promoção do trabalho decente no Brasil, Revista da ABET, São Paulo, v. IX, n. 1, jan./jun. 2010. 
de uma conciliação adequada tornam a vida destas mulheres uma experiência profundamente estressante e desmotivante.

Algumas iniciativas foram tomadas para encaminhar o problema. Na América Latina, a maior parte dos países prevê a licença-maternidade e medidas de proteção ao trabalho da mulher, em maior ou menor grau, como já se evidenciou anteriormente.

É importante inserir a figura do pai neste contexto familiar, para que estas responsabilidades sejam divididas, como deferem as legislações específicas de países como Argentina, Brasil, Chile, Uruguai, Equador, Bahamas, Colômbia, Guatemala, República Dominicana e Venezuela, onde os pais têm direito a uma licença remunerada por nascimento do filho, com duração que varia entre dois e cinco dias. No Equador, a licença é de dez dias; na Venezuela, de 14 dias. Nas Bahamas, o trabalhador tem direito a uma licença não remunerada de sete dias por ano que pode ser usufruída tanto em razão de nascimento de filho/a, quanto em caso de emergências familiares ${ }^{56}$.

Outro fator relevante para a resolução do problema é a existência de creches ou serviços de cuidados infantis à disposição dos trabalhadores e próximos aos locais de trabalho, facilitando a logística familiar, como é o caso de creches e escolas infantis mantidas nas grandes universidades ou em empresas privadas.

Oportuno também mencionar novamente outra importante contribuição da OIT para o entendimento da proteção à maternidade e ao trabalho da mulher, um estudo lançado em 2010, La maternidad en el trabajo, ${ }^{57}$ cujo objetivo foi examinar as legislações nacionais a respeito da matéria, com base nos dados da OIT sobre as leis relacionadas a condições de trabalho e emprego.

O estudo compila dados de duração da licença-maternidade, tipos de licença, leis sobre proteção e não discriminação no emprego, assim como proteção da saúde da mulher no local de trabalho.

Um dado interessante é que, dos países membros da OIT, apenas 63 países ratificaram ao menos uma das três Convenções sobre a matéria. De qualquer modo, a maioria dos países membros declara que concede 14 ou mais semanas de licençamaternidade, por meio de suas legislações pátrias, como é o caso do Brasil.

${ }^{56}$ ORGANIZAÇÃO INTERNACIONAL DO TRABALHO. Trabalho e família: rumo a novas formas de conciliação com co-responsabilidade social, 2009, p. 83.

${ }^{57}$ ORGANIZACIÓN INTERNACIONAL DEL TRABAJO. La maternidad en el trabajo: examen de la legislación nacional. 2. ed. Ginebra: OIT, 2010. 
O estudo indica que um caminho para a conciliação é a manutenção da licençamaternidade, apoio dos empregadores públicos e privados para a guarda de crianças em creches e escolas infantis próximas aos locais de trabalho e a implementação das licenças parentais, visando a maior participação do homem nos cuidados das crianças e afazeres domésticos.

Positivamente, a OIT conclui que tem havido avanços na legislação específica sobre o tema em diferentes regiões do planeta. Mas, como indica a citação do pensamento de Norberto Bobbio, há uma distância considerável entre o estabelecimento de normas internacionais e a aprovação de uma legislação de proteção social. E, outra questão é a efetividade de uma legislação em vigor.

Atualmente, há diversas campanhas em curso da OIT em diversos escritórios regionais espalhados pelo mundo que procuram introduzir novos aspectos ao debate. Mudanças estão ocorrendo, sim, no nível da política social, porém não no nível obrigacional, ao contrário do que ocorre na Espanha, por exemplo. Este debate é trazido como conhecimento doutrinário para o Brasil através da obra da magistrada e pesquisadora Candy Florencio Thome ${ }^{58}$.

Pouco se tem assistido no tocante à mobilização dos governos e dos atores sociais à causa atual da maternidade, que possa ajustar a lei e outras espécies normativas às transformações constantes no mercado de trabalho e na vida da maioria das mulheres do mundo ocidental.

Por sua vez, o movimento sindical também tem se bastado, na maioria dos casos de negociação coletiva, a repetir texto já consolidado em Lei, o que não justifica a própria existência das entidades sindicais. À frente veremos a importância da negociação coletiva para o avanço da questão e o que as negociações têm acrescido ao debate sobre a mulher, maternidade e condições especiais de trabalho.

\footnotetext{
${ }^{58}$ THOME, Candy Florencio. Direitos de conciliação entre trabalho e família: licença-maternidade e licença-paternidade. São Paulo: LTr, 2009.
} 


\section{CAPÍTULO 4}

\section{OUTRAS GARANTIAS LEGAIS E CLÁUSULAS DE NEGOCIAÇÃo COLETIVA}

A proteção legal, como se sabe, neste caso, não se resume à concessão da licençamaternidade. As garantias que conferiram estabilidade da gestante no emprego e o abono de faltas em decorrência de consultas médicas compõem, apenas a título exemplificativo, o arcabouço da proteção.

É clara a importância da negociação coletiva na conquista desta completude. Porém, antes mesmo da inserção mais maciça de cláusulas em instrumentos coletivos a respeito da matéria, destaca-se o papel decisivo do TST para a garantia da proteção.

Afora a própria Constituição e os complementos trazidos pelas legislações infraconstitucionais, alguns entendimentos do TST a respeito da proteção à maternidade contribuíram para esclarecer pontos omissos ou dúbios, causadores de problemas práticos, como o de reconhecimento da estabilidade da gestante, por exemplo.

A Súmula 244 do TST esclarece assim que o desconhecimento do estado gravídico pelo empregador não afasta o direito ao pagamento da indenização decorrente da estabilidade. Ainda, que a garantia de emprego à gestante só autoriza a reintegração se esta se der durante o período de estabilidade, caso contrário, a trabalhadora fará jus apenas aos salários de direitos relativos ao período de estabilidade. Também foi inserida no texto da Súmula, em 2000, a antiga $\mathrm{OJ}^{59} \mathrm{n}^{\mathrm{o}} 196$ cujo teor esclarece que a empregada não tem direito à estabilidade na vigência do contrato de experiência, visto que seu término não caracteriza dispensa arbitrária (antiga Súmula 260).

\footnotetext{
${ }^{59}$ OJ: orientação jurisprudencial.
} 
A antiga Súmula estabelecida pela Resolução Administrativa $n^{\circ} 15 / 85$, trazia a seguinte redação: "A garantia de emprego à gestante não autoriza a reintegração, assegurando-lhe apenas o direito a salários e vantagens correspondentes ao período e seus reflexos".

Assim, a atual redação da Súmula, embora não seja totalmente inovadora, contém mudança positiva, já que agora reconhece o direito da gestante à reintegração no emprego e não meramente a indenização do período ${ }^{60}$.

Portanto, em breves palavras, o que se procura é salientar que a construção do direito social em tela foi também realizada por meio da atividade intensa da corte máxima trabalhista.

Não menos importante, a negociação coletiva também contribuiu para que a proteção à maternidade ganhasse vulto. É verdade que o sindicato, como ator social, propiciou por meio de sua atividade não apenas o cumprimento da legislação, mas a negociação de cláusulas ainda mais favoráveis do que as impostas por lei. Não em todos os casos e de forma geral, mas de forma crescente nos últimos anos.

A negociação coletiva é objetivo precípuo de qualquer ente sindical. Não fosse assim, a figura "sindicato" não haveria de existir, já que existe em função da necessidade de representação dos trabalhadores.

No Brasil, os sindicatos viram reafirmados seus espaços de atuação com a Constituição de 1988 , cujo artigo $8^{\circ}$ e incisos consagram a representação de trabalhadores e o direito de defesa em questões judiciais ou administrativas, individuais ou coletivas.

Dessa forma, inegável o papel importante do sindicato na ordem constitucional democrática no Brasil, assim como em todos os países ditos desenvolvidos.

Conforme afirma Verônica Cavalcante da Fonseca, no âmbito do direito estrangeiro (União Europeia):

"Os sindicatos têm como desafio a luta pela manutenção de salários, pela redução do desemprego e pelo não retrocesso em termos de benefícios conquistados no estado de bemestar social. Isso frente a uma nova realidade que se apresenta ao Estado-membro com

${ }^{60}$ Cf. THOME, Candy Florencio. Direitos de conciliação entre trabalho e família: licençamaternidade e licença-paternidade. São Paulo: LTr, 2009. 
perda de poder de intervenção no mercado e maior pressão das empresas para a descentralização da política salarial, da regulação trabalhista e da negociação coletiva." ${ }^{\circledR 1}$

Feitos estes esclarecimentos, importa, neste capítulo, analisar as principais contribuições das leis infraconstitucionais e da negociação coletiva para a proteção à maternidade.

\subsection{Licença médica, flexibilidade na jornada, estabilidade no emprego}

A Lei 9.799 de 26 de maio de 1999 foi um marco legislativo importante na proteção à maternidade pós 1988, oxigenando um estoque de leis já um pouco estagnadas (aquelas constantes da CLT), para trazer um approach diferenciado sobre gestação e o pós-parto.

Embora sucinta, esta Lei impôs condições de ingresso da mulher no mercado de trabalho e contemplou a gestante com algumas concessões no curso da gravidez. Em termos gerais, possibilitou a retirada da gestante de funções perigosas a transferindo para função compatível, bem como o afastamento para a realização de consultas médicas e exames durante a gestação.

Assim, alterando o dispositivo do art. 392 da CLT, em seu $\S 4^{\circ}$, dispõe os seguintes benefícios:

" $\S 4^{\circ}$. É garantido à empregada, durante a gravidez, sem prejuízo do salário e demais direitos:

I - transferência de função, quando as condições de saúde o exigirem, assegurada a retomada da função anteriormente exercida, logo após o retorno ao trabalho;

II - dispensa do horário de trabalho pelo tempo necessário para a realização de, no mínimo, seis consultas médicas e demais exames complementares."

${ }^{61}$ FONSECA, Verônica Cavalcante. Negociação coletiva na União Européia e no Mercosul. In: FREITAS JR, A. R.; SANTOS, E. R. dos (coord); CAVALCANTE, J. Q. P. (org). Direito coletivo do trabalho em debate. Rio de Janeiro: Ed. Lumen Juris, 2009, p. 325. 
Outro conteúdo interessante que deu redação ao art. 392-A da CLT, em seu inciso IV, veda a exigência de atestado ou exame para comprovação de esterilidade ou gravidez, na admissão ou no curso do contrato de trabalho, como condição para permanência no emprego.

Em termos de efetividade, podemos considerar esta legislação altamente efetiva, pois ao alterar a CLT impôs à iniciativa privada o seu cumprimento, sob pena de fiscalização do Ministério do Trabalho e das entidades sindicais, que buscam estabelecer como mínimo exigível o cumprimento da legislação vigente, sob pena de a empresa sofrer ação individual ou coletiva que busque reparações.

Ótimo exemplo concedeu o Tribunal Superior do Trabalho ao julgar o Dissídio Coletivo em que recorria o MPT e eram recorridos empregados e empregadores do comércio do município de Livramento ${ }^{62}$, no estado do Rio Grande do Sul. O TST decidiu dar provimento ao recurso para indeferir a homologação das cláusulas referentes à estabilidade da gestante e do abono de ponto da gestante.

$\mathrm{Na}$ versão original da norma coletiva, acordada entre as partes, a empregada gestante seria obrigada a apresentar atestado médico, à empresa, dentro de determinado prazo, a fim de comprovar que a gravidez se iniciou em período anterior ao aviso prévio, sob pena de decadência do direito. No entanto, tal critério representa condicionante não prevista no art. 10, II, $b$, do ADCT.

Além de se contrapor a direito constitucionalmente assegurado, a condição poderia acarretar prejuízos à empregada gestante, contrariando, evidentemente, o princípio constitucional da proteção à maternidade. A própria Súmula $n^{\circ} 244^{63}$ do TST estabelece que o desconhecimento do estado gravídico pelo empregador não afasta o direito ao pagamento da indenização decorrente da estabilidade. Em relação ao abono de ponto da gestante, a cláusula homologada permitia a saída da empregada gestante, de seu local de

62 Recurso Ordinário $\mathrm{n}^{\circ}$ TST-RO-209300-54.2009.5.04.0000. Recorrente: MPT. Recorridos: Sindicato do Comércio Varejista de Livramento e Outros, Sindicato dos Empregados no Comércio de Livramento e Sindicato Intermunicipal dos Concessionários e Distribuidores de Veículos no estado do RS.

${ }^{63}$ Súmula 244 Gestante. Estabilidade Provisória. I- O desconhecimento do estado gravídico pelo empregador não afasta o direito ao pagamento da indenização decorrente da estabilidade (art.10, II, b, do $\mathrm{ADCT}$ ) (ex-OJ $\mathrm{n}^{\circ}$ 88- DJ 16.4.404). II- A garantia de emprego à gestante só autoriza a reintegração se esta se der durante o período de estabilidade. Do contrário, a garantia restringe-se aos salários e demais direitos correspondentes ao período de estabilidade (ex-Súmula $\mathrm{n}^{\circ}$ 244- Res. 121/03, DJ 21.11.03). III- Não há direito da empregada gestante à estabilidade provisória na hipótese de admissão mediante contrato de experiência, visto que a extinção da relação de emprego, em face do término do prazo, não constitui dispensa arbitrária ou sem justa causa (ex-OJ nº 196- Inserida em 8.11.2000). 
trabalho, sem prejuízo de seu salário, somente para quatro consultas médicas ou realização de exames, durante toda a gestação, reduzindo direito indisponível, previsto no inciso II do $\S 4^{\circ}$ do art. 392 da CLT, afrontando, também, o art. 227 da Constituição. Portanto, reformou-se a decisão da Corte Regional, indeferindo a homologação dessa norma coletiva.

Normas muito importantes se dirigem também ao pós-parto, sendo aí duas mais significativas: a que visa prolongamento da licença quando diagnosticados problemas de saúde do bebê ou da mãe e aquelas relativas propriamente ao bem-estar do bebê.

Em relação à primeira hipótese, a Lei 10.421 de 2002 possibilitou a extensão da licença por duas semanais adicionais, caso a empregada apresente atestado médico. Em relação à segunda hipótese, são dois os benefícios principais: concessão de horários especiais para aleitamento, conforme art. 396 da CLT (dois intervalos por dia de meia hora cada até o bebê completar seis meses) e benefício que visa mais especificamente o bem do bebê, como a concessão de creche nas empresas que contam com mais de trinta mulheres acima de dezesseis anos de idade.

Para crianças maiores, há interessante cláusula de norma coletiva firmada no ramo químico do interior de São Paulo, pelo Sindicato dos Químicos Unificados com as empresas do ramo químico, plástico e farmacêutico de Campinas, Osasco e Vinhedo. Tal norma, em sua cláusula vigésima primeira, estabelece benefício de reembolso mensal de 90\% (noventa por cento) do salário normativo da categoria para funcionários que comprovem gastos com educação de filhos excepcionais. Sabe-se que os pais têm despesas não previstas com a educação de filhos nascidos com algum tipo de excepcionalidade, outros tantos que deixam de enviar seus bebês para creches especializadas ou escolas infantis especializadas por falta de recursos financeiros. Tal norma concede benefício inédito e um pós-parto também mais tranqüilo para mães de crianças portadoras de necessidades especiais.

Assim, nota-se que nos anos que sucederam a Constituição houve uma capacidade considerável da legislação de adaptação à realidade da maioria das mulheres brasileiras, a fim de auxiliar a conciliação da maternidade com o trabalho. Situações inesperadas como doença da mãe ou do filho e até mesmo dificuldades para amamentar podem ser consideradas situações legítimas para a concessão de licença médica especial, com apresentação de atestado médico.

No pós-parto, além das garantias acima, também houve a criação de normas para assegurar o bem-estar da criança, o que foi reforçado pela norma coletiva. 
Assim, a preocupação tanto do legislador quanto das categorias coletivas foi a de integrar as várias perspectivas que podem elevar o patamar da proteção à maternidade a um lugar de maior amplitude, não somente focado na licença-maternidade em si, como também esteio de uma reorganização de vida e prioridades. Essa é uma das maiores benesses que qualquer normatização pode propiciar.

\subsection{Proteção à maternidade na negociação coletiva}

Embora em capítulos anteriores já se tenha mencionado que a proteção à maternidade foi objeto de preocupação em diversas normas coletivas, aqui se pretende dar um foco mais direto para esta forma de pacto entre os atores do mundo do trabalho. Entenda-se esta seção como extensão ou desdobramento da argumentação anterior.

A questão agora é analisar até que ponto as convenções coletivas de trabalho podem conceder alguma adaptabilidade à trabalhadora gestante ou que condições especiais em relação à maternidade já foram objeto de cláusulas convencionais.

Não se pretende realizar uma análise de todas as convenções coletivas de todos os seguimentos de trabalho, pois esta tarefa foge completamente ao escopo deste estudo. A intenção é explicitar, por meio de exemplos, quais as possibilidades e vantagens que uma negociação coletiva pode trazer em relação à proteção à maternidade.

Nesta toada, vale em primeiro lugar relembrar que atualmente a negociação coletiva de trabalho se posiciona como um dos principais instrumentos de pacificação de conflitos na área coletiva do trabalho, e tal fato é devido, em grande parte, à Constituição de 88 , que a erigiu à hierarquia constitucional. As Constituições anteriores apenas legitimavam a negociação coletiva no momento em que reconheciam as convenções ou contratos coletivos de trabalho ${ }^{64}$. Na CLT a matéria se encontra regulamentada no artigo $616, \S \S 1^{\circ}$, $3^{\circ}$ e $4^{\circ}$.

Assim, as várias convenções firmadas atualmente abordam, de forma superficial ou mais aprofundada, as questões que envolvem o período de licença, a adaptação às condições da gestante ou situações relativas ao pós-parto.

${ }^{64}$ Cf. SANTOS, Enoque Ribeiro dos. A negociação coletiva de trabalho como instrumento de pacificação social. In: THOMÉ, Candy Florencio; SCHWARTZ, Rodrigo Garcia (orgs.) Direito coletivo do trabalho: curso de revisão e atualização. Rio de Janeiro: Elsevier, 2010. 
Importante pesquisa neste sentido foi realizada pelo Dieese, publicada em 2003, analisando dados de 1996 a $2000^{65}$. Esta pesquisa abrange um estudo sobre cláusulas relativas ao tema constantes de acordos e convenção coletivas de trabalho firmadas por algumas das mais importantes categorias profissionais no Brasil.

A pesquisa então que inicialmente norteia esta análise baseou-se no Sistema de Acompanhamento das Contratações Coletivas, desenvolvido para o cadastramento de documentos resultantes do processo de negociação coletiva de trabalho (sistema este que norteou a classificação de cláusulas atualmente utilizada pelo Sistema Mediador do Ministério do Trabalho), que definem as condições de trabalho das diversas categorias profissionais. Foram analisados 94 documentos referentes ao período 1996-2000, abrangendo, aproximadamente, trinta categorias profissionais pertencentes aos setores industrial, comercial e de serviços de catorze estados.

As cláusulas analisadas foram agrupadas em temas, sendo que se dará foco aqui a três temas, os quais mais enriquecem este trabalho: gestação e maternidade/paternidade, responsabilidades familiares e condições de trabalho.

No tema gestação e maternidade, a negociação mais freqüente se refere à estabilidade da gestante, negociada por $85 \%$ das categorias examinadas. Aproximadamente $60 \%$ das categorias que prevêem essa estabilidade em seus contratos repetem as disposições legais com relação a sua duração, ou seja, de cinco meses após o parto. Os outros $40 \%$ ampliam o prazo previsto em lei em períodos que variam de trinta a cento e vinte dias.

Outra garantia negociada é a que assegura função compatível com a gestação, presente nos contratos de doze das noventa e quatro categorias profissionais analisadas (13\%), o que demonstra ainda ser pequena a sua incidência. Além dessas, foram localizadas algumas garantias de saída da gestante antes do término da jornada de trabalho. Apesar de essas cláusulas serem úteis e benéficas (sem dúvida, novidades resultante do processo de negociação coletiva), apenas três categorias profissionais, no universo pesquisado, incluíram-nas em seus contratos coletivos de trabalho.

Também em um número restrito de categorias profissionais (quatro) foi assegurada a dispensa da gestante para exames do pré-natal. Vale ressalvar que posteriormente a esta

${ }^{65}$ DEPARTAMENTO INTERSINDICAL DE ESTATÍSTICA E ESTUDOS SÓCIO-ECONÔMICOS. Negociação coletiva e eqüidade de gênero no Brasil: cláusulas relativas ao trabalho da mulher: 1996-2000. São Paulo: Dieese, 2003. 
conquista na negociação direta entre as partes, a legislação brasileira passou a assegurá-la, em artigo já citado neste estudo.

Foi localizada uma cláusula firmada por uma única categoria profissional que assegura primeiros socorros para o parto, através de transporte de urgência para hospitais. É interessante observar que todas as cláusulas que têm por finalidade dar garantias relativas à gestação referem-se apenas à trabalhadora, excluindo o futuro pai do processo de gestação, ao contrário do que ocorre na Espanha, por exemplo, em que a própria legislação prevê garantias ao pai, conforme se explicitará mais adiante.

As cláusulas incluídas no tema garantias à maternidade/paternidade dizem respeito à compatibilização entre o exercício do trabalho e os cuidados necessários à criação e acompanhamento dos filhos, compreendendo as garantias a pais e mães desde o momento do nascimento da criança.

A pesquisa demonstra que, depois da estabilidade à gestante, as cláusulas sobre guarda dos filhos (creche) são as mais freqüentes no que se refere às questões de gênero, negociadas por cinqüenta e oito categorias profissionais, ou seja, $62 \%$ do universo analisado incluem em seus contratos garantias sobre esse tema.

Em relação ao conteúdo, cerca de $20 \%$ das categorias profissionais que incluem em seus contratos coletivos de trabalho cláusula sobre creche declaram que deverá ser cumprida a legislação sobre o tema. Os $80 \%$ restantes explicitam quais medidas serão adotadas como alternativa à obrigatoriedade das empresas de instalarem berçários ou manterem convênios. Dessas, a grande maioria prevê reembolso parcial dos gastos efetuados.

Em um grande número de contratos, os beneficiários são somente as mães trabalhadoras. Alguns prevêem sua extensão aos pais que se separados, divorciados ou viúvos, desde que detenham a guarda dos filhos e que não estejam casados ou vivendo em união estável. Apenas quatro categorias profissionais garantem o pagamento desse benefício a todos os trabalhadores.

Há uma grande variedade quanto aos valores e períodos durante os quais serão ressarcidos esses gastos. Alguns dos contratos prevêem seu pagamento apenas até o prazo previsto pela legislação, ou seja, até os seis meses de vida da criança, mas a grande maioria o amplia. Foram localizadas garantias de extensão do prazo desde que a criança complete nove até seis anos. 
A maior parte das cláusulas estabelece limite máximo para a restituição dos valores gastos pelas trabalhadoras com creche. Poucos são os contratos coletivos que determinam a cobertura integral dos gastos efetuados.

Outra garantia que apresenta alta freqüência na negociação é o abono de faltas para acompanhamento de filhos. Quase a totalidade das cláusulas aqui registradas relaciona-se ao acompanhamento dos filhos em questões de saúde. Dessas, cerca de $60 \%$ referem-se exclusivamente à internação hospitalar e os outros $40 \%$ a ausências relativas a doenças. A maioria as prevê para consultas médicas ou acompanhamento dos filhos em tratamentos médicos. Algumas convenções garantem a concessão de folgas, nas datas de aniversário de filhos e cônjuges.

Em um menor número de contratos, constam cláusulas referentes especificamente a garantias a trabalhadores com dependentes portadores de deficiência, conforme citado na sessão anterior. A maioria dessas cláusulas assegura cobertura de gastos com educação. Dessas, parte estende o auxílio-creche negociado aos dependentes portadores de deficiência e parte menciona explicitamente o reembolso de despesas efetuadas com educação especializada.

Continuando a exposição dos resultados do estudo do Dieese, merece destaque uma cláusula que garante a trabalhadores que recebem até três salários mínimos, reembolso de $50 \%$ das despesas com medicamentos e/ou tratamento profissional ou hospitalar de filho excepcional ou deficiente físico, limitado a um piso da categoria.

Em relação à licença-maternidade, são constantes as disposições nos documentos firmados por 21 categorias profissionais, significando $22 \%$ do total de documentos analisados. Infelizmente, a grande maioria delas não apresenta avanços em relação à legislação, restringindo-se a transcrever as determinações referentes à duração do período de afastamento, que é estipulado em 120 dias. Em alguns casos, regulamenta-se o cálculo do salário-maternidade das trabalhadoras comissionadas. Em outros, estendem-se os benefícios indiretos às mães em licença.

Sobre a licença-paternidade, trinta e três categorias profissionais a incluem em seus contratos, o que corresponde acerca de 35\% das análises. Igualmente aqui, a maioria dos contratos coletivos que trata da licença reafirma as disposições legais, ou seja, direito à licença ao pai por cinco dias, em virtude do nascimento do filho, sendo que grande parte especifica que estes devem ser consecutivos. Algumas cláusulas prevêem o gozo da licença no decorrer da primeira semana de vida da criança e uma, durante as duas primeiras 
semanas. Embora em pequeno número, algumas cláusulas registradas avançam em relação à legislação quanto ao prazo da licença-paternidade, estendendo-o.

Importante afirmar uma inovação dos instrumentos coletivos: a estabilidade do pai. Algumas poucas categorias profissionais (seis) asseguram estabilidade ao pai, garantia não prevista em lei. O período da estabilidade varia entre trinta, sessenta ou noventa dias.

Em relação à amamentação, foram localizadas nos contratos de dezessete categorias profissionais (18\% do total), algumas garantias às trabalhadoras lactantes, incluindo a prevista em lei, de direito a local para amamentação e dois intervalos, durante a jornada de trabalho, para esta finalidade. A maior parte dos contratos prevê a possibilidade de acumular os dois intervalos para amamentação, de meia hora cada, em um único intervalo de uma hora (prática muito comum nas empresas, já que a maioria das empregadas está longe de casa nos horários da amamentação, não conseguindo nem ao menos se deslocar em meia hora). Excepcionalmente, uma categoria profissional amplia os dois intervalos para 45 minutos, prevendo o deslocamento da mãe (o que também não resolve o problema).

Em dois casos há avanços em relação à legislação, no que se refere ao prazo: um estende a garantia até que a criança complete nove meses de idade, ressalvando que, se houver prescrição médica, este período poderá ser dilatado e outro assegura a redução da jornada diária de trabalho da mãe até que o filho complete doze meses.

Outras convenções ou acordos dispõem sobre as ampliações da licença, nos mesmos moldes do art. 392 da CLT.

Ainda neste tema, foram analisadas cláusulas com garantias aos trabalhadores adotantes. No período analisado, a legislação trabalhista não assegurava garantias aos pais quando da adoção de filho. No total, 35 categorias profissionais acompanhados estendem uma ou mais das garantias relativas à maternidade/paternidade aos pais e mães que adotarem crianças legalmente.

Nos contratos coletivos de cinco categorias profissionais, o prazo da licença é escalonado, superior para a adoção de crianças mais novas e inferior para a adoção de crianças mais velhas. Ainda foram localizados três casos nos quais a licença expira no momento em que a criança completar um determinado número de dias e dois que a fixam em trinta dias, sem mencionar a idade da criança.

Apenas em quatro negociações foi estendido ao pai adotante o mesmo prazo de licença concedido ao pai biológico. Também é bastante reduzido o número de contratos que prevêem estabilidade para adotantes. Das oitenta categorias profissionais que incluem 
cláusulas de estabilidade à gestante, apenas cinco conquistam garantia temporária no emprego para as mães adotantes.

Por fim, interessante observar o resultado da análise em relação às facilidades para o desempenho de responsabilidades familiares. Aqui foram analisadas cláusulas que concedem garantias aos trabalhadores em relação à vida familiar, no que se refere a situações que requeiram sua presença ou na extensão de benefícios a seus dependentes.

Uma das cláusulas mais difundidas neste tema é a garantia de liberação do trabalhador para acompanhamento de cônjuges e/ou familiares que dele necessitarem.

O interessante é perceber que, ao contrário do que ocorreu nos temas anteriores, a cláusula mais freqüente aqui não tem base na legislação, resultando da negociação direta, dado que infelizmente a legislação brasileira não faz referência a esse direito.

Assim, foram localizadas 26 categorias profissionais $(28 \%$ do total $)$ que conseguiram algum tipo de garantia nesse sentido. A totalidade destas cláusulas, porém, refere-se a motivos de saúde, com uma exceção, na qual é assegurada ao trabalhador folga no dia de seu aniversário, de seus filhos e do cônjuge.

$\mathrm{Na}$ grande maioria dos casos, é assegurada a liberação do trabalhador para acompanhamento do cônjuge em internação hospitalar, sem prejuízo do salário. Em apenas dois casos é garantida somente a liberação, sem a respectiva remuneração.

Em cerca de $60 \%$ das cláusulas, o abono é limitado a uma falta. Foram também observados abonos de dois dias (na internação e na alta), de três dias (na internação, no dia da cirurgia e na alta) e pelo número de horas indispensáveis à internação.

Embora quase $80 \%$ das garantias refiram-se apenas ao cônjuge, há as que se estendem à internação de pai e mãe. Em um caso, assegura-se o acompanhamento para tratamento médico fora do domicílio de pessoa da família em primeiro grau.

De um modo geral, podemos concluir que uma grande parte das convenções analisadas traz texto já consolidado na legislação em relação à proteção à maternidade, porém, há parcela considerável que traz em seus instrumentos coletivos uma gama de flexibilidades e adaptabilidades, que somente uma negociação coletiva pode trazer, o que reafirma sua importância e necessidade. Destaque para as cláusulas que prevêem estabilidades e que consideram a figura do pai como partícipe da complexidade da maternidade. 
No caso do direito dinamarquês, por exemplo, embora a negociação coletiva não preveja, a própria Lei que regulamenta a proteção à maternidade ${ }^{66}$ prevê que, após o parto, os pais terão direito a ausentar-se do trabalho durante um período total de vinte e quatro semanas, dez das quais poderão ser utilizadas pelo pai depois da décima quarta semana seguinte ao parto. Este direito só pode ser exercido por um dos pais, de cada vez.

Sem prejuízo dessa licença, o pai poderá ausentar-se, ainda, durante duas semanas depois do nascimento do filho ou da chegada do adotivo, devendo informar ao empregador, mediante um aviso prévio de quatro semanas, a data em que pretende ausentar-se e a duração do afastamento, nos moldes dos artigos $1^{\circ}, 2^{\circ}$ e $4^{\circ}$ da Lei n. 101/87.

Em complemento, cumpre examinar outro estudo, Negociação coletiva e igualdade de gênero na América Latina, ${ }^{67}$ o qual apresenta como principal contribuição uma visão panorâmica sobre as características da negociação coletiva em seis países, Argentina, Brasil, Chile, Paraguai, Uruguai e Venezuela.

Segundo o estudo, destes países analisados, apenas o Uruguai não possui um grau importante de negociação coletiva. Uma característica que preocupa é o intervencionismo estatal existente nestes Estados, o que dificulta a plena autonomia coletiva.

Sem adentrar as especificidades de cada sistema em relação aos instrumentos negociais e regras internas, o que vale é apresentar quais os conteúdos negociados e observar o grau de maturidade destes processos negociais pátrios para o tratamento das questões protetivas à maternidade.

Sendo assim, verificou-se que, dos instrumentos analisados, a atenção relativa à maternidade e paternidade estava presente, em média, em duas cláusulas por convenção (no período de 1996 a 2000).

Em termos de conteúdo, os maiores avanços encontrados foram em relação à: a) ampliação da licença-maternidade; b) instituição e ampliação da licença-paternidade; c) ampliação do período de estabilidade durante a gravidez e após o parto; d) estabilidade do pai em caso de nascimento de um filho; e) garantia de integridade salarial durante a licença-maternidade; f) redução da jornada de trabalho para a mulher grávida; g) ampliação dos horários destinados à amamentação (considerados como tempo de trabalho e

${ }^{66}$ Lei n. 234, de 4 de junho de 1980, complementada pela Lei n. 101, de 6 de março de 1987.

${ }^{67}$ ABRAMO, Laís; RANGEL, Marta. Negociação coletiva e igualdade de gênero na América Latina. Brasília: OIT, 2005. 
remunerado) e ampliação do prazo de duração desse benefício; e h) proteção da saúde da mulher em caso de aborto legal ou não-voluntário.

Abordando a questão dos direitos de conciliação, as principais cláusulas eram relativas à permissão para faltar ao trabalho para acompanhar os filhos por razões de saúde e educação, ampliação da duração e melhoria da qualidade dos serviços de creche e garantias para pais e mães adotivos: licença-maternidade, estabilidade para mães e pais e creche.

O estudo mostra que, de maneira geral, os maiores avanços em relação ao tema proteção à maternidade/paternidade, são as cláusulas relativas à ampliação da cobertura e do prazo destes direitos e a instituição de novos direitos.

Dando seguimento à análise e com intuito de aprofundarmos o entendimento sobre a importância da negociação coletiva para o avanço e para a eficácia da proteção à maternidade no Brasil, cumpre analisar ainda outro estudo mais recente sobre o tema, de autoria da OIT, mas realizado em parceria com o Dieese. Intitulado Negociação de cláusulas de trabalho relativas à igualdade de gênero e raça (2007-2009), ${ }^{68}$ concede contribuição relevante e informações de grande importância e atuais para o tema aqui discutido.

As garantias encontradas no estudo das cláusulas revelam disciplinas relativas a: maternidade/paternidade, desempenho de responsabilidades familiares, condições e exercício do trabalho, saúde da mulher, igualdade de gênero, trabalho do negro e igualdade social, garantias contra a discriminação, isonomia salarial, ações afirmativas e saúde. Importa aprofundar o tema maternidade e desempenho de responsabilidades familiares.

Segundo os dados sobre as garantias relativas à maternidade/paternidade, estas representam quase $50 \%$ do total de cláusulas analisadas. Estas garantias foram negociadas em 23 contratos coletivos, sendo 14 da indústria - dentre as categorias de metalúrgicos, papeleiros, construção e mobiliário, alimentação, vestuário, gráficos, químicos e petroquímicos -, seis de serviços - bancários, professores, enfermeiros e trabalhadores em limpeza ambiental e processamento de dados - e três do comércio.

$\mathrm{Na}$ análise dessa garantia foram consideradas as cláusulas que de alguma forma faziam referência à licença-maternidade. Em alguns casos a cláusula tratava

${ }^{68}$ Cf. ORGANIZAÇÃO INTERNACIONAL DO TRABALHO. Negociação de cláusulas de trabalho relativas à igualdade de gênero e raça: 2007-2009. Brasília: OIT; São Paulo: Dieese, 2011. 
especificamente dos critérios da licença; em outros, estabelecia normas acerca de alguns direitos da trabalhadora durante o período da licença.

Das 16 cláusulas que tratam da duração da licença-maternidade, 14 versam sobre a duração de 120 dias fixados pela primeira lei, e duas - bancários nacional e petroquímicos da Bahia - asseguram a prorrogação da licença-maternidade por mais 60 dias, conforme a nova legislação. Em um caso a garantia à prorrogação foi introduzida em 2009 e no outro em 2008, respectivamente.

Vale destacar uma inovação: um instrumento coletivo analisado assegura licençamaternidade de 130 dias, garantia registrada desde a inclusão dessa contratação no já citado sistema SAC-Dieese, em 2003. A conciliação do gozo de férias com o final da licença-maternidade é objeto de cláusula em uma contratação coletiva. Por fim, vale observar que outras quatro cláusulas convencionais passaram a pactuar a prorrogação da licença-maternidade nos termos da Lei 11.770.

Outro conteúdo proveitoso convenciona a garantia da contagem do período da licença-maternidade para fins de pagamento da PLR e para efeitos de promoção, indicando a amplitude/elasticidade que a negociação coletiva possui, em contrapartida à própria legislação vigente.

Ao se referir à licença paternidade, as cláusulas encontradas não são inovadoras, em sua maioria, chegando a causar certa decepção. Pouco mais de um terço das cláusulas analisadas (222 cláusulas ao todo), apenas repetem o comando no art. 10 da ADCT, $\S 1^{\circ}$, inciso II. Apenas duas cláusulas analisadas ampliaram a licença do pai para 7 ou 8 dias, significando um resultado positivo, porém incipiente.

Com relação ao conteúdo, a maioria das cláusulas fixa o período de estabilidade contado a partir do nascimento, variando entre 30, 60 e 90 dias. Em apenas um caso a estabilidade inicia-se antes do parto, a partir do $8^{\circ}$ mês, e estende-se até 30 dias após. Em alguns casos a garantia é condicionada à comprovação do nascimento.

Apenas uma cláusula apresentou avanços com relação a essa garantia, assegurando estabilidade de 120 dias a partir do nascimento do filho.

Vale citar, por fim, que Em todo o painel analisado, apenas uma unidade de negociação da categoria dos professores conquistou a licença-amamentação. A cláusula assegura licença sem remuneração de até 90 dias, a ser gozada imediatamente após o término do período de licença-maternidade, para fins de amamentação. 
Há as ressalvas de que a trabalhadora lactante deverá ter ao menos um ano no mesmo estabelecimento e que a licença está condicionada a coincidência com o início do semestre letivo e a requerimento prévio.

Em relação à negociação coletiva de cláusulas relativas à proteção à maternidade $\mathrm{e}$ ao trabalho da mulher, incluindo direitos de conciliação, este é o panorama geral e atual no Brasil.

Finalizando a argumentação desta seção, vale alinhavar algumas conclusões.

Parece claro que a negociação coletiva constitui um importante instrumento para a promoção da igualdade de oportunidades no trabalho e proteção à maternidade na América Latina, apesar de ser um processo ainda inconsistente, contrário ao que ocorre na Europa, por exemplo.

Apesar das dificuldades, as organizações sindicais de muitos países latinoamericanos têm encetado esforços significativos no período analisado a fim de incorporar os temas de gênero em suas estratégias de ação. Isso repercute em uma maior presença do assunto tanto nas estratégias negociadoras como nos resultados concretos da negociação coletiva.

Não obstante a repetição dos textos legais, a análise das demandas apresentadas pelos sindicatos à negociação coletiva revela, em muitos casos, uma preocupação com a defesa dos direitos das mulheres trabalhadoras.

Entre as fragilidades citadas pela pesquisa, uma das mais preocupantes é dificuldade de negociar temas relativos às condições de trabalho e de ampliar os conteúdos e o alcance dos temas negociados em relação às responsabilidades familiares, em especial no que se refere à promoção das responsabilidades compartilhadas entre homens e mulheres; em geral, esses são temas pouco debatidos.

Em resumo, parece natural concluir que os temas relativos aos direitos da mulher trabalhadora e à promoção da igualdade de oportunidades são presentes e importantes nos processos de negociação coletiva nos seis países analisados.

Em relação especificamente ao Brasil, é necessário avançar muito mais para desenvolver o potencial da negociação coletiva em relação ao trabalho da mulher e, conseqüentemente, em relação à proteção à maternidade. A expansão desta garantia legal e a abrangência deste benefício a todas as trabalhadoras brasileiras depende, em grande parte, da atuação do movimento sindical. 
Um tema a ser discutido e que merece ser analisado, por exemplo, é a inclusão das mulheres que estão na informalidade. Poucos sindicatos têm discutido a questão da flexiseguridade, por exemplo, que possibilitaria uma condição especial de licenciamento para trabalhadoras precárias. Neste sentido, parece que o governo federal deu um passo à frente e mais ágil que o movimento sindical.

Ao instituir o programa $\mathrm{MEI}^{69}$, propiciou a inclusão previdenciária de milhares de mulheres brasileiras que sobrevivem de trabalhos precários, informais e vulneráveis. Essa ação possibilitou as mesmas o gozo da licença-maternidade, mediante inclusão no programa em condições específicas.

Não cumpre aqui julgar se este instituto representa o melhor caminho para o enfrentamento da questão, mas importa lançar um olhar sobre o problema, com intuito de fomentar um debate entre os atores sociais envolvidos, desempenhando papel fundamental as entidades sindicais. O tema é instigante e rico, porém e infelizmente, não será possível aprofundá-lo, já que foge ao escopo desta investigação.

Por derradeiro, parece ser urgente a necessidade de desenvolver a capacidade propositiva dos sindicatos em relação aos temas protetivos ao trabalho da mulher, incluindo igualdade de oportunidades e incremento de cláusulas robustas sobre a conciliação do trabalho e da família nas mesas de negociação; é necessário promover a sensibilização do setor empresarial na matéria.

É preciso, ainda, que o Estado promova políticas públicas de caráter social tratando a matéria. Conciliar a maternidade com as responsabilidades profissionais trará enormes benefícios ao fortalecimento de valores como a cidadania e educação, por exemplo, já que as crianças e os jovens poderão contar com a presença de seus pais em várias ocasiões importantes da vida, não apenas quando do nascimento ou da amamentação. Essas medidas poderão fortalecer os vínculos familiares e oxigenar as relações parentais.

Por outro lado, é importante investir no conhecimento dos trabalhadores, sindicatos e empresários sobre as desigualdades e os obstáculos conciliatórios nos setores produtivos, suas causas e conseqüências, podendo este incremento no conhecimento gerar capacidades de reflexão e proposituras capazes de superá-los.

${ }^{69}$ A Lei Complementar 128 de 19/12/2008 instituiu condições especiais para o trabalhador considerado informal passar a ter uma condição legalizada. Com o cadastro requerido no sistema nacional do MEI, micro empreendedor individual, e a contribuição de R\$ 32,14 (comércio e indústria) e R\$ 36,14 (serviços), o trabalhador passará a gozar de benefícios como aposentadoria e licença-maternidade. Condições: faturar, no máximo, até $\mathrm{R} \$ 60.000 .00$ ao ano e não possuir vínculo empregatício ou contratual como sócio de empresa. Para mais informações, consultar www.portaldoempreendedor.gov.br. 


\section{CAPÍTULO 5}

\section{AMPLIANDO O ESCOPO DA PROTEÇÃO}

A maternidade não é realizada apenas pelos meios tradicionais e biológicos, digamos assim. Há outras formas de uma mulher se tornar mãe (e um homem se tornar pai), formas estas cada vez mais frequentes na sociedade atual e que merecem atenção dos legisladores e aplicadores do Direito.

Atualmente, várias tecnologias estão voltadas para a geração de seres humanos, como a fertilização in vitro e a inseminação artificial. Em ambos os casos, o bebê pode ser gestado pela mãe ou por outra mulher, pois o ovo já está pronto, bastando apenas um local para se desenvolver. Portanto, mãe não é somente aquela que dá o filho à luz, porque em alguns casos, ela realmente não dá. Em outros, ocorre a adoção ou a relação maternal, como nos casos de mães sociais.

É importante buscar outras reflexões ainda não exploradas no trabalho, mas não menos relevantes. Estas situações de maternidade ou condições não tradicionais merecem uma atenção especial, quer por fazerem parte da sociedade moderna, quer por apontarem no cenário internacional como tendências jurídico-legislativas, quando o tema é proteção ao trabalho da mulher e proteção à célula família.

Esta discussão tem se desenvolvido na Europa acerca do envolvimento de outras pessoas, que não a própria gestante, nos misteres da maternidade, além do apontamento de alguns aspectos relevantes que poderiam ensejar uma legislação nacional adequada com esta realidade e ainda em sintonia com as tendências internacionais mais arrojadas e preparadas para promover a integração de toda a sociedade na conciliação entre trabalho e família. 


\subsection{Proteção à mãe adotante $\mathrm{e}$ à mãe social}

A proteção normativa à mãe adotante foi evoluindo conforme evoluíram todos os direitos relativos às mulheres. Conforme já mencionado, somente com o advento do Decreto n. 21.417-A, de 1932, é que foi assegurado à mulher o descanso obrigatório de quatro semanas antes e após o parto, passíveis de ampliação por meio de atestado médico, a faculdade de romper o pacto laboral se a atividade fosse prejudicial à gravidez, descanso de duas semanas em caso de aborto, dois intervalos diários para amamentação durante os seis primeiros meses de vida da criança, proibição de demissão da mulher grávida, bem como a proibição de prestação de serviços em ambiente insalubre ou perigoso ${ }^{70}$.

Outro grande salto rumo ao reconhecimento da igualdade de gênero ficou ao encargo da Constituição Cidadã, que além de estender a licença-maternidade para cento e vinte dias, também concedeu garantia de emprego à gestante desde a confirmação da gravidez até cinco meses após o parto ${ }^{71}$.

No entanto, não vislumbrou o mesmo direito à mãe adotante, que continuou marginalizada da legislação. Havia, à época, entendimentos jurisprudenciais diversos, que ora reconheciam, ora não o direito de licença-maternidade à adotante, à luz do citado art. $7^{\circ}$ da Constituição.

As garantias, portanto, estavam atreladas à mãe grávida e amamentante, expressamente limitantes à condição biológica da maternidade. É curioso observar que a mesma Constituição de 88 , em seu artigo 227 , VII, $\S 6^{\circ}{ }^{72}$ veda a prática discriminatória entre filhos naturais e adotivos!

Somente com o advento da Lei 10.421 de 2002, este cenário começou a ser modificado. Fruto de alguns projetos de lei, tais como os de número 1.733/96 e 3.822/00, por exemplo, esta lei versou sobre a concessão de licença e salário maternidade para as empregadas adotantes. Embora esta legislação signifique um avanço extraordinário em relação ao vácuo legislativo que antes imperava, tal iniciativa foi sancionada já com

\footnotetext{
${ }^{70}$ Cf. FREDIANI, Yone. Licença-maternidade à mãe adotante: aspectos constitucionais. São Paulo: LTr, 2004.

${ }^{71}$ Arts. $7^{\circ}$, XVIII e 10, II, b da Constituição Federal de 1988.

72 Art. 227, VII, $\$ 6^{\circ}$. Os filhos, havidos ou não da relação do casamento, ou por adoção, terão os mesmos direitos e qualificações, proibidas quaisquer designações discriminatórias relativas à filiação (grifos meus).
} 
máculas de constitucionalidade, objeto de pesadas críticas dos juristas e pesquisadores do Direito do Trabalho.

Da leitura do texto legislativo in verbis se compreende a indignação:

Art. 392-A. À empregada que adotar ou obtiver guarda judicial para fins de adoção de criança será concedida licença-maternidade nos termos do Art. 392, observado o disposto no seu $\S 5$.

$\S 1$ o - No caso de adoção ou guarda judicial de criança até 1 (um) ano de idade, o período de licença será de 120 (cento e vinte) dias.

$\S 20$ - No caso de adoção ou guarda judicial de criança a partir de 1 (um) ano até 4 (quatro) anos de idade, o período de licença será de 60 (sessenta) dias.

$\S 30$ - No caso de adoção ou guarda judicial de criança a partir de 4 (quatro) anos até 8 (oito) anos de idade, o período de licença será de 30 (trinta) dias.

Como se observa, a lei condiciona o período de gozo da licença-maternidade à adotante de acordo com a idade do adotado. Excetuando-se a criança de até 1 ano (cujo o período da licença é o mesmo das empregadas gestantes), há redução do prazo à metade (ou seja, 60 dias), se o mesmo tiver entre 1e 4 anos.

Ainda mais sensível é a redução do período de gozo da licença se o adotado possuir de 4 até 8 anos : exatos $1 / 4$ do período concedido à mãe biológica, ou seja, apenas 30 (trinta) dias. E, lastimavelmente, não há previsão de licença à empregada que adotar criança que possua idade superior a 8 anos (Assunção, 2007).

Incongruente a legislação infraconstitucional à luz dos princípios da igualdade, bem como da proteção integral, preceituado no ECA- Estatuto da Criança e do Adolescente.

No direito estrangeiro, há parecidos indícios de desrespeito ao princípio da igualdade, quando comparada a licença da mãe biológica com a da mãe adotante.

No direito francês, a legislação de 1980 que deu redação ao Código do Trabalho Francês, concede desde então à adotante licença, chamada de suspensão do contrato durante dez semanas após a chegada do filho adotivo ao lar, sendo estendido a doze semanas em caso de adoção múltipla. Este período de afastamento poderá ser divido entre a mãe e o pai, desde que a licença não se fracione em mais de dois períodos e que a mais curta seja inferior a quatro semanas, conforme art. 122-26 do CTF, cc. Arts. 525/529 do Código de Seguridade Social Francês. 
Porém, no mesmo país, a assalariada grávida tem direito, ainda, de afastar-se, suspendendo-se o contrato a partir de seis semanas anteriores à data presumida do parto e até dez semanas após o parto ${ }^{73}$.

Visível diferença entre as duas formas de maternidade. Poderia haver e há justificativas que caminham na direção de preparação da mulher para o parto. Porém, qual não é também trabalhoso chegar aos momentos finais de um processo de adoção, passar pelo momento de adaptação até, finalmente receber seu fillho ou seus filhos em casa?

Parece aqui haver também diferenciação entre a chegada de filhos naturais e a chegada de filhos adotivos.

Felizmente, em 2009 foi editada a Lei n. 12.010 de 29 de julho, que modificou esta perspectiva no plano nacional. A referida Lei, que também trata da sistemática da adoção em si, repara a injustiça concedendo à mãe adotante licença-maternidade semelhante à concedida à mãe biológica, quando afirma os princípios da igualdade, da proteção integral e do interesse superior da criança e do adolescente (art. 100), em especial. Por fim, a Lei revoga os $\S \S 1^{\circ}$ e $3^{\circ}$ do art. 392-A da CLT.

Outra forma de proteção à figura da mãe ou da maternidade surgiu da preocupação do Estado, de juristas, de psicólogos e assistentes sociais e da própria sociedade, quando olharam para a situação de milhares de crianças e jovens que se encontram em abrigos, após a dissociação da família natural.

O Estado e a sociedade entendem que é preciso reproduzir a figura da mãe nos muitos abrigos e casas, a bem destes pequenos que estão, durante este período, sob a tutela do próprio Estado. Essa figura é a mãe social, cujo surgimento no Brasil se deu em 1987, com o advento da Lei 7.644 de 18 de dezembro daquele ano, que dispôs sobre a regulamentação da atividade da mãe social.

$\mathrm{O}$ art. $2^{\circ}$ da Lei define o que é a mãe social:

Art. $2^{\circ}$. Considera-se mãe social, para efeito desta Lei, aquela que, dedicando-se à assistência ao menor abandonado, exerça o encargo em nível social, dentro do sistema de casas-lares.

${ }^{73}$ Cf. BARROS, Alice Monteiro de. A mulher e o direito do trabalho. São Paulo: LTr, 1995. 
As casas-lares são unidades residenciais que abriguem até dez menores. Há casos em que se forma um agrupamento de casas lares, o que geralmente é chamado de aldeia.

Em suma, as responsabilidades de uma mãe social são organizar o lar, propiciando um ambiente saudável e zelar pelo desenvolvimento dos menores, igualmente desempenha este papel qualquer mãe tradicional, porém, neste caso, realizando essas atividades com exclusividade e residindo na casa-lar.

À mãe social são assegurados vários direitos, já que ela é considerada uma empregada da própria casa lar. São eles anotação na CTPS, remuneração, em valor não inferior ao salário mínimo, repouso semanal remunerado de 24 (vinte e quatro) horas consecutivas, apoio técnico, administrativo e financeiro no desempenho de suas funções, 30 (trinta) dias de férias anuais remuneradas nos termos do que dispõe o capítulo IV, da CLT, benefícios e serviços previdenciários, inclusive, em caso de acidente do trabalho, na qualidade de segurada obrigatória, $13^{\circ}$ (décimo terceiro) salário e Fundo de Garantia do Tempo de Serviço ou indenização, nos termos da legislação pertinente ${ }^{74}$.

A jurisprudência há muito vem reconhecendo, com base na Lei, a proteção trabalhista à mãe social, conforme jurisprudência do TST abaixo:

\section{"MÃE SOCIAL" (OU MÃE-CRECHEIRA) - LEI N 7.644/87 - FEBEM - VÍNCULO DE EMPREGO.}

A prestação de serviços pela mãe social, com fulcro na Lei ${ }^{0}$ 7.644/87, caracteriza contrato de trabalho, na medida em que presentes a pessoalidade, a onerosidade e a subordinação. Esse contrato reveste-se, no entanto, de natureza especial, em razão de os artigos $5^{\circ}$ e 19 da referida lei disporem, de forma expressa e exaustiva, sobre os direitos assegurados, entre os quais se incluem férias remuneradas, gratificação de Natal, anotação da CTPS, benefícios previdenciários, repouso semanal remunerado e indenização ou levantamento do FGTS, no caso de dispensa sem justa causa. Recurso de embargos não provido. ${ }^{75}$

Esta profissional candidata a mãe se submeterá a um processo seletivo no qual são exigidas boa conduta e habilidade para a função, além de idade mínima de 25 (vinte e cinco) anos, boa sanidade física e mental, além de ter sido aprovada em treinamentos e estágio exigidos pela própria Lei.

\footnotetext{
${ }^{74} \mathrm{http}$ ://www.jusbrasil.com.br/legislacao/anotada/2387001/art-5-inc-viii-da-lei-7644-87.

${ }^{75}$ TST: Embargos em Recurso de Revista: 5921982219995045555, Subseção I Especializada em Dissídios Individuais, Publicação: DJ 09/06/2006.
} 
Percebe-se assim, um intento da legislação em abarcar no sistema social e legislativo a figura da mãe como empregada e que atua como profissional nesta função social tão basilar. A proteção à maternidade não se dirige apenas à mulher, mas aos filhos, à família, a toda a sociedade. No caso dos menores abandonados, a proteção somente conseguiu se estender por meio da mãe artificial, ou seja, esta figura fictícia criada sob a roupagem de empregada, mas com o dever de desempenhar papel familiar. Sob a ótica da mãe social, sua proteção é o resguardo de seus direitos trabalhistas. Sob um aspecto mais subjetivo, poderíamos dizer que sua proteção é a concedida pela própria sociedade que aprova e mais do que isso, necessita de sua atuação.

Assim, o argumento aqui proposto e que se confirma é que a expansão da garantia legal, ainda que criando figura de mãe fictícia, mais uma vez, pode ser ferramenta para a ampliação da proteção, já que o princípio da proteção integral do ECA e os princípios constitucionais da pessoa humana se estendem à todos os menores e não somente àqueles pertencentes às famílias naturais.

A grande crítica que se faz a esta criação jurídica vem da área de psicologia. Segundo analisam alguns estudos, a modalidade de organização em pequenos grupos, reunidos em uma casa, constitui inegável avanço em relação às condições anteriores de abrigamento. Contudo, algo ainda se faz problemático nesse arranjo. Trata-se da ilusão de se acreditar possível reproduzir o amor materno dentro da instituição. É o que se costuma chamar o "mito do amor materno institucional"76. Será possível reproduzir no contexto do abrigo e dos cuidados coletivos essa complexa rede de afetos, motivações e fantasias que determinam psiquicamente a interação na díade mãe-criança?

A reflexão acima é demasiada importante para o aprimoramento do escopo de trabalho e do perfil que se espera da mãe social. Esta reflexão nos conduz ao questionamento da própria figura criada, porém, a despeito das reflexões e críticas que se possam levantar, o que parece prevalecer é a centralidade do papel destas profissionais na vida de milhares de crianças e jovens residentes de casas-lares. Manter a atuação destas mães fictícias e aperfeiçoar estes laços é falar sobre o próprio princípio da proteção à maternidade.

${ }^{76}$ FRANÇA, Dirce Barroso. Mãe social: o mito da reprodução do amor materno nas instituições de abrigo. In: ATEM, Lou Muniz (org.) Cuidados no início da vida: clínica, instituição, pesquisa e metapsicologia. São Paulo: Casa do Psicólogo, 2008. 


\subsection{Proteção à maternidade: direitos de conciliação entre trabalho e família e a nova divisão sexual do trabalho}

A problemática dos direitos sociais no contexto do século XXI também reside na questão da nova divisão sexual do trabalho, da proteção normativa à maternidade e dos chamados direitos de conciliação entre trabalho e família.

Se antes o conceito passava pela ordem mulher-casa e marido-emprego, atualmente se pode olhar as relações gênero e trabalho sob novo approach: relação de trabalho antagônica entre homens e mulheres, por conta de diferenças de remuneração e postos de trabalho qualificados.

O conceito tradicional que se utiliza mormente nos escritos das ciências sociais, e principalmente neste estudo, vem das pesquisas da eminente socióloga Helena Hirata ${ }^{77}$, para quem a divisão sexual do trabalho é, primariamente, a forma de divisão do trabalho social decorrente das relações sociais entre os sexos; mais do que isso, é um fator prioritário para a sobrevivência da relação social entre os sexos. Para ela, essa forma é modulada histórica e socialmente. Tem como características a designação prioritária dos homens à esfera produtiva (qualificada) e das mulheres à esfera reprodutiva e, simultaneamente, a apropriação pelos homens das funções com maior valor social adicionado (políticos, religiosos, militares etc.).

Ainda, é preciso esclarecer que esta forma particular da divisão social do trabalho tem dois princípios organizadores: o princípio de separação (existem trabalhos de homens e trabalhos de mulheres) e o princípio hierárquico (um trabalho de homem "vale" mais que um trabalho de mulher). Esses princípios são válidos para todas as sociedades conhecidas, no tempo e no espaço. Podem ser aplicados mediante um processo específico de legitimação, a ideologia naturalista. Esta rebaixa o gênero ao sexo biológico, reduz as práticas sociais a "papéis sociais" sexuados que remetem ao destino natural da espécie.

Atualmente, se fala e se reflete a respeito de uma nova divisão sexual do trabalho ${ }^{78}$, cujas principais características seriam: 1) a reorganização simultânea do trabalho no campo assalariado; 2) a nova divisão do trabalho doméstico (o maior envolvimento de certos pais é acompanhado de um envolvimento quase exclusivo no trabalho parental, inclusive no

${ }^{77}$ HIRATA, Helena. Dicionário crítico do feminismo. São Paulo: Ed. Unesp, 2010.

${ }^{78}$ Cf. HIRATA, Helena; KERGOAT, Danièle. Novas configurações da divisão sexual do trabalho. Cadernos de Pesquisa, Fundação Carlos Chagas, v. 37, n. 132, set-dez. 2007. 
cuidado do recém-nascido); 3) acentuação das clivagens entre mulheres que atuam em profissões de nível superior e aquelas em situação precária (desemprego, flexibilidade, precarização).

Outra característica deste novo modelo de divisão do trabalho deve ser pensado. É preciso refletir a divisão sexual do trabalho como "vínculo social", pois é ela que fundamenta a tese (inclusive da política adotada da União Européia), da "conciliação" vida familiar/vida profissional. O problema é colocar a mulher como sendo a única que deve conciliar, ou seja, a presença implícita de um alvo da norma. O ideal é que homens e mulheres conciliem a vida familiar e as atividades dela decorrentes, inclusive as atividades em torno da maternidade e não que impere o status quo segundo o qual homens e mulheres não são iguais perante o trabalho profissional.

Infelizmente, a defasagem entre modelo e realidade das práticas sociais faz com que, em geral, caiba exclusivamente às mulheres conciliar vida familiar e vida profissional, carecendo, então, da proteção normativa principalmente em caso de maternidade, a fim de garantir sua volta ao emprego de forma estável. Alguns países europeus estão aumentando a licença-paternidade a fim de contornar o problema deste tipo de conciliação.

Como não cabe aos homens o cuidado do nascituro, sua volta ao trabalho é rápida, propiciando que ele vivencie a paternidade e continue assegurando seu posto de trabalho. Tal situação revela uma clivagem entre homens e mulheres sob o aspecto da empregabilidade, acentuando uma das características da nova divisão sexual do trabalho, aqui sob o aspecto da maternidade, ou seja, não importa somente para a nova conceituação a diferença qualitativa da ocupação de postos de trabalho, mas a forma mais ou menos gravosa que se desenrola o conciliação do aumento da família com a ascensão no emprego.

Mulheres que gozarão da licença-maternidade dificilmente serão conduzidas a cursos de aperfeiçoamento e, de forma bem restrita, serão promovidas a cargos de responsabilidade compatíveis com os postos ditos "masculinos" (médios e altos cargos de direção), principalmente aquelas em idade fértil.

Portanto, podemos pensar que a divisão sexual do trabalho é sempre indissociável das relações sociais entre homens e mulheres, que são relações desiguais, hierarquizadas, assimétricas e antagônicas. A divisão sexual do trabalho é, assim, indissociável das relações sociais entre homens e mulheres, que são relações de exploração e de opressão entre duas categorias de sexo socialmente construídas ${ }^{79}$.

\footnotetext{
${ }^{79}$ HIRATA, Helena. Dicionário crítico do feminismo, 2010.
} 
Para que estes impactos sejam menores para as mulheres que desejam ser mães, a legislação, de fato, precisa incidir disciplinando a questão, protegendo a maternidade, sob todas as suas formas, seja com a mãe biológica ou adotante, para que haja condições mínimas de assistência durante o afastamento e garantia de emprego em seu retorno, evitando retaliações e discriminações do empregador.

No tocante à conciliação entre trabalho e família, a idéia mais importante é a de que, nas relações de emprego, a mulher acaba sendo discriminada por ser de sua incumbência o cuidado do lar, dos filhos, dos enfermos e dos idosos.

Como explica Candy Florencio Thome, a garantia da conciliação da vida laboral e familiar como desdobramento do princípio da igualdade entre os sexos deve, todavia, ter em conta que essas medidas de conciliação devem possibilitar e fomentar a criação de uma nova corresponsabilidade familiar, com o compartilhamento das responsabilidades familiares e domésticas entre o pai e a mãe ou entre os dois progenitores (em caso de casais homossexuais). O princípio da igualdade entre os sexos é preconizado pelo artigo 12 da Convenção das Nações Unidas sobre a eliminação de todas as formas de discriminação contra a mulher, em vigor desde 16 de abril de 1982:

"[Esta norma internacional] concebe a discriminação contra a mulher como toda distinção, exclusão ou restrição fundada no sexo e que tenha por objetivo ou resultado prejudicar ou anular o reconhecimento, gozo ou exercício dos direitos humanos e das liberdades fundamentais pela mulher, qualquer que seja seu estado civil, nos mais diversos campos." $\$ 0$

No Brasil, a Constituição (art. $7^{\circ}$ ) consagra para os empregados o direito à proteção do mercado de trabalho da mulher (art. $7^{\circ}$ inciso XX), por meio de incentivos específicos, conforme a lei e o direito à proibição de qualquer discriminação quanto a salário e critérios de admissão do trabalhador deficiente. Todavia, mesmo com a Constituição de 1988, são incipientes as políticas de incentivo ao trabalho da mulher ou ações afirmativas neste sentido, com exceção de algumas poucas medidas como a criação da Secretaria Especial de Políticas Públicas para as Mulheres, cuja missão é estabelecer políticas públicas que

\footnotetext{
${ }^{80}$ THOME, Candy Florencio. Direitos de conciliação entre trabalho e família: licença-maternidade e licença-paternidade. São Paulo: LTr, 2009, p. 18.
} 
contribuam para a melhoria da vida das brasileiras e que reafirmam o compromisso do Governo Federal com as mulheres do país ${ }^{81}$.

Mas não há normas específicas que prevejam a conciliação entre trabalho e família no Brasil, nos mesmos moldes desenvolvidos na Europa, em especial na Espanha. Geralmente, pai e mãe compartilham alguns momentos juntos no cuidado com o nascituro durante o período em que o pai está em licença-paternidade (5 dias concedidos pela $\mathrm{CF} / 88$ ), sendo considerado pouco este período, tendo em vista os cuidados específicos que um bebê recém-nascido requer e as condições de recuperação da mãe no pós-parto. A Convenção Coletiva dos Professores do Rio Grande do Sul, por exemplo, concede à categoria licença-paternidade de 8 (oito) dias ${ }^{82}$, justamente nesta esteira de entedimento.

Há no Brasil, atualmente, uma proposta de emenda à Constituição (PEC n. 114/07) que concede ao pai estabilidade no emprego durante a gravidez de sua mulher - nos casos em que o salário do pai seja a única fonte de renda da família - o que é importante para a criança - uma vez que o Brasil não ratificou a Convenção n. 158 da OIT e não há uma estabilidade geral no emprego ${ }^{83}$.

Nada mais prevêem tais normas a respeito dos direitos de conciliação do trabalho e da família ou da participação do pai nas responsabilidades da maternidade.

\footnotetext{
${ }^{81}$ Percorrendo uma trajetória transversal em todo o governo federal, de modo a estabelecer parcerias com diversas instâncias governamentais, a SPM enfrenta as desigualdades e diferenças sociais, raciais, sexuais, étnicas e das mulheres deficientes. A SPM trabalha com as mulheres, para as mulheres e pelas mulheres. A Secretaria foi criada através da Medida Provisória 103 (veja a íntegra no rodapé da página), no primeiro dia do governo do presidente Luiz Inácio Lula da Silva, para desenvolver ações conjuntas com todos os Ministérios e Secretarias Especiais, tendo como desafio a incorporação das especificidades das mulheres nas políticas públicas e o estabelecimento das condições necessárias para a sua plena cidadania. É competência da SPM: i. assessorar direta e imediatamente o Presidente da República na formulação, coordenação e articulação de políticas para as mulheres; ii. elaborar e implementar campanhas educativas e não discriminatórias de caráter nacional; iii. elaborar o planejamento de gênero que contribua na ação do governo federal e das demais esferas de governo; iv. promover a igualdade de gênero; $v$. articular, promover e executar programas de cooperação com organismos nacionais e internacionais, públicos e privados, voltados à implementação de políticas para as mulheres; vi. promover o acompanhamento da implementação de legislação de ação afirmativa e definição de ações públicas que visem ao cumprimento dos acordos, convenções e planos de ação assinados pelo Brasil, nos aspectos relativos à igualdade entre mulheres e homens e de combate à discriminação, tendo como estrutura básica o Conselho Nacional dos Direitos da Mulher, o Gabinete e três Subsecretarias (SEPM no sítio da Presidência da República).

${ }^{82}$ Convenção Coletiva de Trabalho, SINPRO/RS, 2010-2011.

${ }^{83}$ Proposta de Emenda à Constituição (PEC) 114/07, do deputado Arnaldo Vianna (PDT-RJ), que concede estabilidade no emprego ao pai de família durante a gravidez da esposa. O benefício será assegurado nos casos em que o salário do pai seja a única fonte de renda familiar. O objetivo é evitar desequilíbrio econômico e desestruturação da família. Pela proposta, o período de estabilidade será garantido a partir da confirmação da gravidez até o quarto mês após o parto. Andamento: em 01/02/2008, encaminhado à Comissão de Constituição e Justiça e de Cidadania para o parecer do Relator.
} 


\section{CAPÍTULO 6}

\section{AVANÇOS LEGISLATIVOS RECENTES DA PROTEÇÃO À MATERNIDADE}

A proteção à maternidade no Brasil foi incrementada com a Lei 11.770/2008, que instituiu a prorrogação facultativa da licença-maternidade para cento e oitenta dias com contrapartida em incentivo fiscal por meio do programa Empresa Cidadã, alterando a Lei 8.212 de 1991.

Embora esta Lei não tenha alterado o texto constitucional do art. $7^{\circ}$, XVIII, significou um marco na rediscussão das condições instituídas para o gozo da licençamaternidade após a histórica modificação de 1988.

Para uma melhor compreensão deste processo legislativo, indaga-se: qual a contribuição social da ampliação da licença de 120 para 180 dias? Qual foi a discussão que antecedeu o sancionamento desta Lei? Esta ampliação afirma ou ameniza o problema da discriminação da mulher no mercado de trabalho?

$\mathrm{Na}$ tentativa de elucidar estas questões, este capítulo está estruturado em três seções. A primeira seção apresentará o discurso dos atores sociais e a argumentação que se deu em torno do tema, anteriormente à aprovação do Projeto de Lei 281/2005.

Após, o que se discute é a concretização da Lei referida e seus desdobramentos no âmbito jurídico e social, inclusive abrindo discussão para o novo Projeto de Lei, desta vez uma PEC, Projeto de Emenda Constitucional 30/2007, cujo objetivo é tornar a licençamaternidade de 180 dias uma obrigação constitucional e não mais uma faculdade, conforme status atual (PEC de iniciativa da deputada Rita Camata, com apoio da Sociedade Brasileira de Pediatria). 
Na seqüência e por último, entendeu-se adequado tecer alguns comentários sobre a repercussão geral da matéria no Supremo Tribunal Federal.

Importante chamar atenção para o diálogo interno que se estabelece entre os capítulos segundo e sexto deste estudo, cuja vertente principal é trazer à vista a importância do resgate das discussões travadas entre os atores sociais no contexto da ampliação dos direitos sociais.

\subsection{Argumentos a favor e contrários aos projetos de lei}

$\mathrm{Na}$ década passada, uma nova discussão entre os atores sociais se deu em torno da ampliação da licença-maternidade. Desta vez, a mudança se referiu a novo período de afastamento: de 120 para 180 dias, nos termos apresentados pelo PL 281/2005.

Realizou-se audiência pública do Senado Federal (21/03/2007), evento sediado em Brasília, com a presença de Comissões de Assuntos Sociais (CAS) e de Direitos Humanos $(\mathrm{CDH})$ do Senado Federal para analisar o referido Projeto de Lei da Senadora Patrícia Saboya Gomes (PPS/CE).

Alguns foram os Projetos de Lei apresentados ao Senado brasileiro nos últimos anos com intuito de dar nova regulamentação ao benefício da licença-maternidade, cada qual tratando aspecto diverso, como prorrogação em caso de parto antecipado ou extensões maiores do que as previstas em lei, mas somente em decorrência de negociação coletiva.

Nesta ocasião, estiveram presentes para realizar o debate, além de autoridades do Governo, por meio das citadas Comissões, entidades sindicais e representantes da iniciativa privada (o empresariado de vários ramos). Uma das falas apresentadas para debate e que representou o pensamento de grande parte da iniciativa privada foi a do Professor José Pastore ${ }^{84}$, cujos argumentos são contrários ao Projeto apresentado.

Analisando sua argumentação, há pontos que merecem destaque. Em primeiro lugar, há que ficar clara a intenção de investigação científica deste estudo e não a crítica deliberada ao pensamento do respeitável Professor, que, aliás, conduz sua argumentação de

${ }^{84}$ PASTORE, José. Licença-maternidade de 180 dias. Texto apresentado na Audiência Pública do Senado Federal, Brasília, 21/03/2007. Disponível em: http://www.josepastore.com.br/artigos/rt/rt 111.htm. Ver, também, PASTORE, José. A proteção da maternidade. Revista do Direito Trabalhista, v. 13, n. 7, p. 3, jul. 2007. 
forma inteligente e embasada. Não se pode negar a importância de sua crítica ao Projeto, que hoje é Lei; pelo contrário, tal crítica merece reflexão. Mas no escopo do presente estudo, sua argumentação não deve prosperar.

A princípio, cumpre ressaltar os termos nos quais o projeto se apresentou.

O Programa Empresa Cidadã sugere adesões de forma voluntária, para estender a licença-maternidade das trabalhadoras por mais 60 dias, desde que solicitada pela empregada até o final do primeiro mês após o parto, conforme comentado anteriormente. Durante a prorrogação, a empregada terá direito à remuneração integral e essa remuneração será efetuada pela empresa. Em contrapartida, a empresa terá direito a deduzir o valor integral pago no cálculo do seu imposto de renda.

Os argumentos levantados no referido discurso se fundam na comparação da licença brasileira com outras concedidas em diversos países estrangeiros e na crítica à informalidade.

Assim, em primeiro lugar, José Pastore afirma que a licença-maternidade concedida no Brasil, de 120 dias, já é uma das maiores no mundo, comparando-se a países como Áustria, Dinamarca e Espanha. Reforça que a OIT recomenda, por meio da Convenção 183, pelo menos 14 semanas de licença paga pela Previdência Social.

Quando a comparação se volta aos países das Américas, o Brasil, notadamente, ocupa patamar privilegiado, frente a países como Estados Unidos e Austrália, que nem sequer possuem previsão de afastamento por conta da Previdência Social.

Cumpre ressaltar, antes de prosseguir, que nos Estados Unidos, desde 1993, vigora a FMLA - Family and Medical Leave Act - a Lei da Família e Licença Médica (tradução própria), cujo objetivo é conceder licença sem vencimentos para os cuidados no pós-parto ou após a adoção de menores. Esta Lei inclui licenças para conciliação entre trabalho e família, como a licença do homem para cuidado dos filhos ou de familiares adoentados.

Embora os Estados Unidos sejam um país desenvolvido, há que se criticar este caráter não remuneratório das licenças e afirmar que o Brasil não possui condições estruturais de sofrer comparação com este tipo de ordenamento jurídico.

Outro argumento explorado pelo Professor em seu discurso é o mal indireto que a extensão da licença-maternidade pode causar: o incentivo à fecundidade. Para esta linha de pensamento, a extensão nos países desenvolvidos está ligada diretamente ao incentivo do Estado ao aumento de taxas populacionais. Enquanto a média de filhos nos países nórdicos é de 1,8 filhos por família, no Brasil, estes índices chegam a 3,02 filhos por mulher.

Em suas próprias palavras: 
"No caso do PLS 281/2005, a prorrogação da licença em 60 dias, deverá estimular a reprodução, elevando a taxa de fecundidade. Há que se considerar que esse benefício se somará a outros dois de grande importância na estimulação da natalidade, a saber, o salário família e a bolsa família, ambos mantidos com recursos do Estado." ${ }^{85}$

Por fim, o argumento explorado e que amarra o raciocínio diz respeito à falta de cobertura destes benefícios protetivos à maternidade à grande massa de mulheres que se encontra à margem da formalidade. Segundo o Professor:

“É conveniente ainda contrastar esse objetivo com as várias carências que ainda persistem nas áreas do emprego, da saúde, da educação e da segurança. A informalidade chega perto de $60 \%$ no Brasil e entre as mulheres ultrapassa esse percentual. Não seria mais prioritário aumentar a formalização e, portando, o número de gestantes que precisam gozar do direito atual (licença de 120 dias)?"

A fim de estabelecer uma contra-argumentação, vale realizar as considerações a seguir na mesma ordem em que foram levantadas.

A princípio, cumpre dizer que, de fato, a licença-maternidade brasileira já se encontra num patamar digno, se comparada aos países desenvolvidos citados. No entanto, nestes países onde o padrão de direitos sociais está estabelecido há dezenas de anos, a rede de proteção social encontra-se muito mais aprimorada. Lá, além do período de licença da mulher, por vezes, o pai também goza de uma licença adequada à participação na chegada do filho, como o caso da Alemanha, por exemplo, onde a licença paternidade é de 12 a 14 semanas, havendo percepção de $67 \%$ do salário, sob a condição de as últimas duas semanas serem gozadas alternativamente pela mãe ou pelo pai.

Portanto, não é apenas a duração da licença que indica a qualidade da proteção.

Sobre a elevação das taxas de natalidade (ou fecundidade), podemos considerar que o argumento não se sustenta, per se. Segundo indicam estudos na área de demografia, a taxa de natalidade vem caindo ano a ano por motivos diversos. Um novo padrão demográfico tem se revelado como o novo perfil da população brasileira: a das famílias menores e de um país com menos crianças, ou seja, nossa população está envelhecendo.

\footnotetext{
${ }^{85}$ PASTORE, José. Licença-maternidade de 180 dias, 2007, p. 7.

${ }^{86}$ PASTORE, José. Licença-maternidade de 180 dias, 2007, p. 8.
} 
Especialmente na zona rural brasileira, a taxa de fecundidade vem caindo por causa dos esclarecimentos crescentes a respeito dos métodos contraceptivos.

Já na zona urbana, um dos fatores de maior influência na taxa de fecundidade é a inserção da mulher no mercado de trabalho e nas carreiras acadêmicas. Conforme reiteramos neste estudo, a mulher vem conquistando mais e mais espaço de realização, dentro de uma sociedade que se mostrou, até há pouco, uma sociedade patriarcal.

Segundo dados do IBGE, ${ }^{87}$ a taxa de fecundidade atual é de 2,07 filhos por mulher (e não 3,02 filhos por mulher).

Por isso, contrapõe-se o argumento de que a ampliação da licença-maternidade possa influenciar substantivamente a taxa de fecundidade, dados que os motivos que promovem a queda destas mesmas taxas e a mudança no perfil populacional brasileiro não confirmarem tal alegação.

Por fim, no que diz respeito à parcela de mulheres que não se encontra protegida pelo benefício da licença-maternidade, de fato, é preocupante. Quase $60 \%$ das trabalhadoras brasileiras, segundo José Pastore, encontram-se em subempregos ou empregos informais e precários. Dentre eles se podem citar o comércio ambulante informal e a prestação de serviços autônomos. São costureiras, manicures, cabeleireiras, depiladoras, vendedoras ambulantes, vendedoras de cosméticos e muitas outras ocupações conhecidas. É uma infinidade de atividades; e, a cada dia, uma nova se revela.

Embora este seja um aspecto de extrema importância social e mereça destaque e aprofundamento, não é objeto central deste estudo. Esta dissertação tem como foco a discussão da proteção à maternidade e sua ampliação, com base no emprego formal. Por isso, não cumpre aqui o aprofundamento do debate da questão da informalidade (lembrando que existem trabalhadoras informais que são assalariadas e outras que trabalham por conta própria). Talvez no futuro seja apresentado um projeto de lei destinado a ampliar a proteção nesta direção, mas não é disto que tratava o PL 281/2005.

Em resumo, mais uma vez, assim como nas discussões da Constituinte, o discurso conservador não comprovou sua veracidade. Mais uma vez os argumentos foram postos de forma contrafactual, com previsões que não se confirmaram.

87 INSTITUTO BRASILEIRO DE GEOGRAFIA $\mathrm{E}$ ESTATÍsTICA. Indicadores sociodemográficos e de saúde no Brasil. Rio de Janeiro: IBGE, 2009. 
Embora o Congresso Nacional não tenha sido convencido pelos argumentos conservadores, ainda assim, vale ressaltar a importância do debate de todas as vozes da sociedade em torno das decisões que irão afetar a maioria. Ressalta-se, também, que fóruns sociais e audiências públicas reforçam, de maneira positiva, a importância do debate e da necessidade de espaços coletivos para exercício das liberdades inerentes à democracia.

\subsection{A Lei 11.770/2008 e seus desdobramentos}

Após discussão, a proteção à maternidade no Brasil (conforme se discutiu), foi incrementada com a Lei 11.770/2008, derivada do Projeto de Lei 281/2005, que instituiu a prorrogação facultativa da licença-maternidade para cento e oitenta dias com contrapartida em incentivo fiscal por meio do programa Empresa Cidadã, alterando a Lei 8.212 de 1991 (ver Anexo 1).

Embora esta Lei não tenha alterado o texto constitucional do art. $7^{\circ}$, XVIII, significou um marco na rediscussão das condições instituídas para o gozo da licençamaternidade após a histórica modificação de 1988.

A prorrogação mencionada refletiu, em parte, os anseios da Sociedade Brasileira de Pediatria, cujo presidente participou ativamente da criação do projeto de lei originário. $\mathrm{O}$ fundamento principal para tal prorrogação foi o período de amamentação de seis meses, sem o qual o recém-nascido deixa de atingir os níveis desejáveis de saúde e desenvolvimento.

As condições necessárias para que a empregada seja beneficiada na iniciativa privada, além da adesão da empresa, são, segundo o art. $1^{\circ}, \S 1^{\circ}$ da Lei, que ela requeira o benefício até o final do primeiro mês após o parto e que não exerça nenhuma atividade remunerada durante o afastamento. Outra condição é que a criança recém-nascida não freqüente durante este período, creche ou organização similar $\left(\operatorname{art.} 4^{\circ}\right)$.

Em contrapartida, a empresa concedente poderá deduzir do imposto devido, em cada período de apuração, o total da remuneração integral da empregada pago nos sessenta dias de prorrogação da licença-maternidade, sendo vedada a dedução como despesa operacional e desde que seja tributada com base no lucro real. 
$\mathrm{Na}$ iniciativa privada, algumas empresas aderiram espontaneamente ao Programa, a exemplo da empresa Nestlé, que ampliou a concessão da licença-maternidade as suas empregadas já em 2007. Primeiro, a empresa manifestou seu apoio ao Projeto na audiência pública que ouviu as empresas no Senado. Após, num evento da companhia em Florianópolis, o diretor de Recursos Humanos, João Dornellas, anunciou que a empresa havia concluído estudo sobre os impactos financeiros da concessão e que os benefícios superavam os custos. Segundo ele, a empresa está convencida de que os primeiros seis meses são muito importantes para a criança ${ }^{88}$.

A multinacional Unilever também aderiu ao Programa em 2010 e suas funcionárias já podem gozar o benefício, desde que manifestem sua opção no prazo legal.

Boas notícias. Todavia, Nestlé, Unilever e algumas outras empresas refletem exceção, tendo em vista que a grande maioria das empresas privadas não manifestou interesse em apoiar a legislação.

Para o setor público, a prorrogação da licença foi autorizada pelo art. $2^{\circ}$ da Lei, instituindo o programa para as servidoras da administração pública, direta, indireta e fundacional e está sendo gozado por parcela de empregadas. No Poder Judiciário Trabalhista, por exemplo, magistradas e servidoras já podem gozar do benefício, já que em 29 de Outubro de 2008, o então Presidente do TST, o Ministro Rider Nogueira de Brito concedeu a prorrogação a todas as magistradas e servidoras do quadro ${ }^{89}$.

Infelizmente, no nível da administração direta municipal, embora o art. 2. ${ }^{\circ}$ tenha autorizado a implementação do Programa, para que seja concretizado é necessário que a municipalidade adira ao mesmo, o que várias delas ainda não realizaram.

Foi o caso da municipalidade de São Luiz do Paraitinga, no Vale do Paraíba, estado de São Paulo. Em 2008, uma mãe no gozo da licença-maternidade se socorreu do Judiciário Trabalhista para ver assegurado o direito de permanecer mais tempo em casa com o recém-nascido (por recomendação médica atestada), uma vez que o mesmo necessitava de cuidados especiais, já que sofria de refluxo, doença do aparelho gástrico comum entre os bebês.

${ }^{88}$ SBP Notícias: ${ }^{\circ} 50$ ano X, agosto/setembro de 2007.

${ }^{89}$ Ato Conjunto n.31/2008 - TST. CSJT- dispõe sobre a prorrogação da licença-maternidade e à adotante, de que trata a Lei 11.770 de 9 de setembro de 2008, no âmbito da Justiça do Trabalho. 
A mãe temia voltar ao trabalho e deixar o filho aos cuidados de terceiros em creches ou berçários, onde a atenção não seria tão intensa ao seu bebê por conta da quantidade de crianças que lá são cuidadas diariamente. Obvio que a mãe temia pela vida de seu filho e sentia a necessidade de estar com ele nesta fase mais delicada da amamentação.

Neste caso, em brilhante decisão prolatada pelo então Juiz do Trabalho, o Dr. Guilherme Guimarães Feliciano ${ }^{90}$, foi decidido que a municipalidade de São Luiz do Paraitinga deveria conceder de imediato uma licença adicional de duas semanas, nos termos do artigo $392, \S 2^{\circ}$ da CLT.

Conforme explica o próprio magistrado, em princípio a Lei. 11.770/2008 pertence àquela classe de leis trabalhistas de aplicação condicionada ${ }^{91}$, que se tornaram relativamente comuns na década de noventa. A empregada teria direito aos 180 dias de licença apenas em três casos: a) na iniciativa privada, por adesão ao Programa Empresa Cidadã; b) na iniciativa pública, por lei, já que atos administrativos encontrariam limitações na LRF (Lei de Responsabilidade Fiscal); c) de um modo geral, por meio da negociação coletiva, onde fosse admitida. O fato, porém, é que alguns Tribunais têm estendido a garantia por outras vias (judiciais e administrativas) ${ }^{92}$.

Atualmente, importante passo em direção à evolução da questão foi dado, tendo em vista que tramita no Senado, após ser aprovada pela Câmara dos Deputados em 2010, Proposta de Emenda Constitucional da Deputada Rita Camata (PSDB/ES), de número 30/2007, que visa, esta sim, alterar o texto constitucional para estender a todas as trabalhadoras a licença-maternidade de cento e oitenta dias.

Segundo a deputada, "hoje, poucas mulheres têm acesso ao benefício. Com a previsão constitucional, todas as trabalhadoras que contribuem com o INSS terão direito a 180 dias de licença-maternidade e também à estabilidade de sete meses"93.

\footnotetext{
${ }^{90}$ Excelentíssimo Senhor Doutor Juiz do Trabalho Dr. Guilherme Guimarães Feliciano da $1^{\text {a }}$ Vara do Trabalho de Taubaté/SP, no ano de 2008.

${ }^{91}$ Entende-se, aqui, que a aplicação da lei ordinária está condicionada às hipóteses lançadas na seqüência. Na ordem constitucional, a doutrina clássica classifica os comandos segundo sua eficácia em: a) normas constitucionais de eficácia plena; b) normas constitucionais de eficácia contida e c) normas constitucionais de eficácia limitada.

92 Esclarecimentos do magistrado quando do exame de qualificação desta dissertação.

${ }^{93}$ Cf. reportagem de fevereiro de 2010: “Comissão aprova licença-maternidade obrigatória de 180 dias". Portal JusBrasil, 11.fev.2010.
} 
Conforme expõe a deputada, inova o Projeto no tocante à ampliação da estabilidade da empregada, que hoje é de cinco meses e passaria a ser de sete meses após o parto.

A proposta da PEC 30/2007 vem harmonizar algumas divergências que juristas e magistrados estabeleceram com a atual Lei 11.770/2008. A crítica aponta vários problemas, desde sua restrita abrangência até possíveis problemas de constitucionalidade.

Apontam que a possibilidade de prorrogação abrange um número muito pequeno de trabalhadoras ${ }^{94}$ e que, ao invés de fomentar a corresponsabilidade familiar, cria um fosso ainda maior entre a licença-maternidade e a licença-paternidade, consolidando o preconceito de que o cuidado dos filhos é incumbência apenas da mulher.

Por fim, cria condição de duvidosa constitucionalidade, que é a impossibilidade de a mãe, no período de prorrogação, deixar a criança em creche ou organização similar, diante da ingerência na forma de cuidado da criança ${ }^{95}$.

Atualmente, a PEC 30/2007 encontra-se no Senado, para apreciação da Comissão de Cidadania e Justiça (matéria com a Relatora).

Uma grande parcela da iniciativa privada argumenta que a expansão da licença em caráter obrigatório aumentaria, em muito, o custo do trabalho Brasil, que consideram já bastante alto.

É certo que a ampliação da licença em caráter obrigatório e geral resultará num significativo avanço do direito social em relação ao trabalho da mulher e em relação à proteção da criança, sem causar grandes impactos financeiros no custo do trabalho.

Segundo cálculos da própria autora e relatora da PEC, os gastos adicionais com a medida serão de R $\$ 1,69$ bilhão ao ano, o que representa menos de $1 \%$ do total gasto com todos os benefícios da Previdência, que em 2009 somaram R $\$ 217$ bilhões $^{96}$. O acréscimo seria de R\$ 1,84 bilhão e R \$ 2,03 bilhões, para os anos de 2011 e 2012. Importante frisar que a empresa acabaria arcando apenas com os dois meses excedentes à atual licença, hoje suportada integralmente pela Previdência Social.

Um dos aspectos mais importantes a ser considerado é o benefício que este direito trará à conciliação entre o trabalho e a família neste momento de evidente instabilidade da economia mundial e competitividade de mercados, momento em que a convivência doméstica parece estar sendo protelada e por estes motivos, justificada.

\footnotetext{
${ }^{94}$ Considerando-se o número crescente de trabalhadoras que se encontram na informalidade.

${ }^{95}$ Cf. THOME, Candy. Direitos de conciliação entre trabalho e família: licença-maternidade e licença-paternidade, 2009.

96 “Comissão aprova licença-maternidade obrigatória de 180 dias”. Portal JusBrasil, 11.fev.2010.
} 
O discurso da comunidade de recursos humanos das grandes companhias corrobora a idéia de que as pessoas precisam se dedicar ao máximo ao trabalho e "entregar" resultados cada vez mais eficientes e desafiadores. Porém, e ao mesmo tempo, este mesmo trabalho se manifesta como elemento de insegurança e insatisfação, porque apesar desta expectativa em relação ao trabalhador, a contrapartida do empregador não está inteiramente assegurada, vide a facilidade que a própria legislação estabeleceu para a dispensa sem justa causa, legitimando a rotatividade da mão-de-obra.

A crescente dificuldade em se assegurar a conciliação entre os interesses do trabalho e da vida pessoal parece indicar um momento de crise para o mundo do trabalho. Segundo o sociólogo Zygmunt Baumann,

"O trabalho não pode mais oferecer o eixo seguro em torno do qual envolver e fixar autodefinições, identidades e projetos de vida. Nem pode ser concebido com facilidade como fundamento ético da sociedade ou como eixo ético da vida individual." ${ }^{97}$

Apesar disso e diante deste período de incertezas e turbulências para o empregado sempre cobrado de mais dedicação, superação e priorização, a concessão do benefício da presença da mãe nos primeiros meses de vida do recém-nascido parece ser "uma luz no fim do túnel". Trata-se de mais uma iniciativa de conciliar um pouco vida familiar e trabalho. Diante de estratégias de negócios mais agressivas e da constante requisição de energia dos trabalhadores em suas tarefas em detrimento da convivência social e familiar, penso que a referida PEC, se aprovada, poderá ajudar a equilibrar.

\subsection{Repercussão geral da matéria previdenciária no STF}

O instituto da repercussão geral merece, de antemão, alguns esclarecimentos a fim de tornar a exposição mais rica e esclarecedora.

$\mathrm{O}$ advento da Emenda Constitucional $n^{\circ}$ 45/2004 trouxe a necessidade de análise em nível de repercussão geral dos recursos extraordinários endereçados ao Supremo

\footnotetext{
${ }^{97}$ BAUMAN, Zygmunt. Modernidade líquida. Rio de Janeiro: Jorge Zahar, 2001, p. 160.
} 
Tribunal Federal. O instituto foi regulamentado mediante alterações no Código de Processo Civil e no Regimento Interno do Supremo Tribunal Federal.

É uma ação com objetivo na sistematização das decisões e das ações necessárias à plena efetividade e à uniformização de procedimentos internos. Assim, esta sistematização de informações destina-se a auxiliar na padronização de procedimentos no âmbito do Supremo Tribunal Federal e dos demais órgãos do Poder Judiciário, de forma a garantir a racionalidade dos trabalhos e a segurança das partes nos processos, tudo com base na Constituição, artigo 102, $\S 3^{\circ}$, acrescido pela Emenda Constitucional n ${ }^{\circ} 45 / 04$ e Código de Processo Civil, artigos 543-A e 543-B, acrescidos pela Lei $\mathrm{n}^{\mathrm{o}} 11.418 / 06^{98}$.

As principais finalidades do instituto da repercussão geral são delimitar a competência do STF, no julgamento de recursos extraordinários, às questões constitucionais com relevância social, política, econômica ou jurídica, que transcendam os interesses subjetivos da causa e uniformizar a interpretação constitucional sem exigir que o STF decida múltiplos casos idênticos sobre a mesma questão constitucional ${ }^{99}$.

A existência da repercussão geral da questão constitucional suscitada é requisito necessário para o conhecimento de todos os recursos extraordinários, inclusive em matéria penal e a verificação da existência da preliminar formal é de competência concorrente do Tribunal, Turma Recursal ou Turma de Uniformização de origem e do STF.

A análise sobre a existência ou não da repercussão geral, inclusive o reconhecimento de presunção legal de repercussão geral, é de competência exclusiva do STF.

Assim, o Supremo Tribunal Federal considerou tema de repercussão geral ${ }^{100}$ a obrigação das empresas de recolherem ao Instituto Nacional do Seguro Social (INSS) a contribuição previdenciária sobre o valor da licença-maternidade pago às trabalhadoras,

${ }^{98}$ Regimento Interno do STF: Artigo $n^{\circ} 13$, com a redação das Emendas Regimentais $n^{\circ} 24 / 2008, n^{\circ}$ 29/2009 e no 41/2010; Artigos $n^{\circ} 21,340$ e 341, com a redação das Emendas Regimentais $n^{\circ} 41 / 2010$ e 42/2010; Artigos no 38, 57, 59, 60, 67, 78, 323-A e 325-A, com a redação da Emenda Regimental n ${ }^{\circ}$ 42/2010; Artigos no 322-A e n ${ }^{\circ} 328$, com a redação da Emenda Regimental no 21/2007; Artigo $n^{\circ} 324$, com a redação das Emendas Regimentais $n^{\circ} 31 / 2009$ e no 41/2010; Artigo no 328-A, com a redação da Emenda Regimental $n^{\circ} 23 / 08$ e da Emenda Regimental no 27/2008 e Portaria 138/2009 da Presidência do STF.

${ }^{99}$ Conforme RISTF.

100 Despacho que decidiu pela existência de repercussão geral: O Tribunal, por ausência de manifestações suficientes para a recusa do recurso extraordinário (art. 324, parágrafo único, do RISTF), reputou existente a repercussão geral da questão constitucional suscitada. Não se manifestaram os Ministros Ellen Gracie e Gilmar Mendes, tendo se manifestado pela recusa do recurso extraordinário os Ministros Carlos Britto, Cármen Lúcia, Celso de Mello, Cezar Peluso, Eros Grau e Menezes Direito e pelo reconhecimento da repercussão geral da questão constitucional suscitada os Ministros Joaquim Barbosa, Marco Aurélio e Ricardo Lewandowski. Em 26/04/2008. 
suspendendo as ações sobre o assunto nas instâncias inferiores até julgar a constitucionalidade da cobrança ${ }^{101}$.

Atualmente, a licença-maternidade é um dos benefícios sobre os quais o Judiciário entende ser devido o pagamento da contribuição ao INSS. No caso do auxílio-doença, auxílio-creche ou auxílio-escolar, por exemplo, o próprio STJ já julgou não ser devida a contribuição. Mas em relação à licença-maternidade, o Tribunal entende (e com razão) tratar-se de um benefício de natureza salarial, para o qual há previsão em lei de cobrança previdenciária.

Para as demais situações, o STF tem julgado que não há contraprestação de trabalho, o que afastaria a natureza salarial.

Sob o aspecto tributário, um argumento contra a decisão reiterada seria o de que um dos fatos geradores da seguridade social seria o rendimento pago pela empresa à pessoa física que lhe preste serviço, como prevê o artigo 195 da Constituição Federal. No caso da licença-maternidade, a empregada não estaria prestando serviço, portanto, a licença não seria uma remuneração paga ao serviço prestado. Este entendimento é frágil.

De fato, antes de 1999 as empresas pagavam a licença-maternidade, cuja duração é de quatro meses, diretamente às trabalhadoras e recebiam posteriormente o reembolso desses valores do INSS. Em 1999, porém, a regra mudou com a Lei nº 8.876.

Pela referida norma, a partir de março de 2000, o pagamento passaria a ser feito diretamente pelo INSS. Para alguns, a medida "descaracterizou" a natureza de salário da licença-maternidade. Por isso, no período em que a norma esteve em vigor, muitas empresas conseguiram prosperar com ações que discutiam o tema. No entanto, a doutrina trabalhista, em sua maioria, entende devido o recolhimento ao INSS, conforme demonstra a decisão de primeira e segunda instância no leading case que fundamentou a repercussão geral da matéria ${ }^{102}$.

A discussão jurídica é belíssima e, mais importante, é de interesse coletivo. Por um lado, a diversidade de decisões a respeito da matéria e, por outro, o anseio das empresas em verem atendida sua reivindicação de há muito, são motivos legítimos para a instauração da repercussão geral da matéria. Uma decisão em sede de Suprema Corte deste país porá

101 Tema 72: Inclusão do salário-maternidade na base de cálculo da Contribuição Previdenciária incidente sobre a remuneração. Relator: Ministro Joaquim Barbosa. Último andamento: conclusos com o Relator com Parecer da Procuradoria Geral da República, em 18/08/2009. da $4^{\mathrm{a}}$ Região.

${ }^{102}$ Recurso Extraordinário em AMS n. 2006.70.00.01.9937-4/PR - Tribunal Regional do Trabalho 
fim a uma discórdia que envolve matéria de Direito do Trabalho, previdenciária e empresarial.

E mais, consagrará o período de licença como motivo de suspensão do contrato de trabalho (afirmando entendimento geral) e considerará as prestações devidas ao órgão previdenciário originárias de salário. Espera-se este o entendimento final da discussão e a extensão deste mesmo entendimento no futuro, caso a PEC citada altere a Constituição, estendendo a licença de 120 para 180 dias, em caráter obrigatório. 


\section{CONCLUSÃO}

“A Constituição Federal impõe sua implementação concreta, não somente nos princípios citados e demais direitos fundamentais do art. $5^{\circ}$, tais como o direito à vida, à liberdade, à intimidade, honra, privacidade etc., como também assegurando os direitos sociais presentes no art. $6^{\circ}$, ao meio ambiente equilibrado e sadio do art. 225 etc. [...] é preciso que se lute por sua implementação, e é dever de todos os operadores do Direito - diga-se novamente - implementá-la, torná-la eficaz."

É certo que a maternidade exige flexibilidades, adaptações, deslocamento de prioridades. E que a relação de trabalho deve conciliar estas nuances com a necessidade jacente de mantença do emprego e da renda. Mas, cada sociedade tem uma maneira particular de tratar o assunto; cada época traz seus desafios, seus mitos, suas promessas.

Estas considerações finais, mais do que fazer uma síntese dos principais argumentos apresentados, pretendem sugerir algumas conclusões a respeito da problemática discutida com base em pesquisa documental, coleta de dados e fundamentação teórica. Tendo em vista a complexidade do tema, não é tarefa fácil encontrar consensos, sendo mais instigante evidenciar as polêmicas. De qualquer forma, expõe-se a seguir uma interpretação construída ao longo dos anos dedicados ao estudo da expansão da garantia legal da proteção à maternidade no Brasil.

$\mathrm{O}$ assunto aqui tomado como foco é de extrema relevância social e merece um tratamento de igual responsabilidade.

Ao fim, o que se quer é contribuir com a academia e com a própria sociedade, para que se encontrem caminhos claros, justos e efetivos para a condução de políticas públicas e

\footnotetext{
${ }^{103}$ NUNES, Rizzatto. Manual de filosofia do direito. 2. ed. São Paulo: Saraiva, 2009, p. 374-5.
} 
iniciativas legislativas que permitam adequar a centralidade do tema com os desafios da atualidade do mundo do trabalho.

Efetividade encontra espaço de destaque nestas conclusões. Assim, pergunta-se: a expansão da garantia legal, no caso da proteção à maternidade aqui verificada, gerou, por si, a efetividade da prestação?

Inevitável relembrar que no sentido conceitual dos direitos sociais fundamentais em Alexy, estes representam prestações positivas em face do Estado. Teria a expansão pesquisada garantido uma amplitude da exigência da mulher de direito à prestação positiva em face do Estado? Neste caso, se sim, qual a efetividade desta prestação?

De fato, a trajetória do instituto da proteção à maternidade no Brasil foi amparado pelas Constituições, que, cada qual em seu tempo, pôde vislumbrar uma parte ou um aspecto do trabalho da mulher e da proteção à gestante e à amamentante, entregando uma garantia social significativa. Tudo isso, obviamente, sob a forte influência dos movimentos e legislações estrangeiras, que se constituíram, por vezes, sob a adesão a convenções internacionais.

O momento decisivo para a elevação dos direitos sociais ao patamar constitucional, no Brasil, sem dúvida foi a promulgação da Constituição de 1988, que consagrou a proteção à família e à mulher, assegurando condições mais adequadas em relação à maternidade, como a extensão da licença de 90 para 120 dias, bem como instituindo licença paterna de 8 dias.

Apesar dos discursos conservadores à época que alegavam a crise do setor econômico e a acentuação da discriminação da mulher no mercado de trabalho, provou-se aqui que a economia brasileira continuou crescendo e a participação do trabalho da mulher no mercado de trabalho cresceu no comércio, na indústria e nos serviços.

Concomitantemente, movimentos da OIT apoiaram as conquistas das mulheres. A maior parte dos países signatários da ONU (Organização das Nações Unidas) assinou e recepcionou em ordenamentos pátrios as convenções relativas à proteção à maternidade.

Aqui, além da ratificação das convenções pertinentes, o TST (Tribunal Superior do Trabalho), em diversas decisões, entendimentos e após, jurisprudência consolidada, traduziu a importância destes institutos e assegurou a efetivamente da prestação jurisdicional e social às milhares de mulheres que se socorreram da Justiça do Trabalho para verem atendidos seus direitos. 
$\mathrm{Na}$ mesma toada, diversos magistrados em primeiro grau contribuíram para a efetividade da proteção (vide decisão analisada).

Por sua vez, a negociação coletiva impactou grandemente a efetividade da proteção desta garantia, trazendo em suas pautas os assuntos integrantes da proteção à maternidade, periféricos, mas não menos importantes, como a flexibilidade na jornada, garantia no emprego além do assegurado em Lei e licenças médicas para a realização de tratamentos e exames especiais, além de alguns vislumbres direcionados às próprias crianças, quando nascidas em condições de saúde adversas.

Inegável a importância do movimento sindical para a luta de trabalhadoras e para a história de conquistas de direitos das mulheres no trabalho em âmbito nacional. Vide o peso destas mobilizações no contexto da Constituinte. Vide o peso destas mobilizações na aprovação da Lei 11.770/2008. Vide o peso destas mobilizações nas inúmeras cláusulas coletivas analisadas pelas pesquisas da OIT, escritório Brasil.

Infelizmente, inúmeros sindicatos neste país não ocupam o lugar devido nos movimentos sociais, deixando de cumprir sua função social de representação da vontade dos trabalhadores. Às vezes com posturas inflexíveis e agressivas. Às vezes com posturas corruptas e negligentes, mais preocupados com a arrecadação das contribuições do que com o bem-estar de seus representados. Assim, vão construindo histórias e trajetórias que repelem os trabalhadores, ao invés de atraí-los. Estes sindicatos deveriam deixar de existir.

Felizmente, inúmeros sindicatos ocupam seus lugares nos movimentos e debates sociais, cumprindo seu dever constitucional e institucional, construindo histórias de conquistas, respeito, evolução e contribuição legítima. Estes sindicatos devem permanecer.

É com representatividade e legitimidade que os direitos dos trabalhadores e, principalmente, das mulheres trabalhadoras serão reconhecidos, ampliados, valorizados.

Por sua vez, as legislações relativas à mãe adotante dizimaram as desigualdades de afastamento em relação à mãe natural e elevaram a proteção da criança e do adolescente ao patamar da proteção integral.

O papel do Estado também impulsionou a criação de outra figura materna, diferente das mães naturais e adotivas, que são as mães sociais.

Legislação própria assegurou a estas mães a proteção de direitos trabalhistas, tendo em vista que desempenham papel tão crucial e nobre para toda a sociedade. Espera-se esta proteção possa aumentar e propiciar mais do que os direitos trabalhistas, mas também o direito de permanecer por mais tempo no emprego, a fim de acompanhar o crescer das 
crianças menores (talvez algum tipo de estabilidade especial), evitando, assim, a rotatividade da figura "mãe-social" nas casas lares.

Apesar de proteção de todas estas figuras e da importância que se dá ao trabalho da mulher, não se pode esquecer preocupante realidade, que se traduz num problema social atual: o problema da informalidade. Infelizmente, grande parcela de mulheres trabalhadoras não é amparada por estas legislações, pois integrantes do mercado informal, cada vez mais crescente no Brasil. Apesar deste aspecto merecer se melhor analisado, apenas cita-se, mas não se argumenta propriamente a respeito da questão, por fugir do escopo desta dissertação.

A transformação da figura da mulher na sociedade carece de adequação mais realista, visando os direitos de conciliação entre trabalho e família, tema explorado em capítulo próprio. Os dias atuais revelam uma nova divisão sexual do trabalho e uma nova configuração das famílias no mundo todo. No Brasil, são cada vez mais freqüentes as famílias monoparentais ou aquelas que dependem exclusivamente do trabalho da mulher. É preciso evoluir. O Direito acompanha a evolução social e é para isso que os legisladores devem olhar quando se entregam à atividade legislativa.

Conclui-se, assim, que neste caso específico, a ampliação da proteção à maternidade pode constituir ferramenta para o aperfeiçoamento da eficácia da proteção, ao contrário do que os atores conservadores afirmaram e ainda afirmam de modo ideológico e contrafactual. No entanto, não se pode afirmar que toda expansão da garantia legal necessariamente promova o aperfeiçoamento da eficácia da proteção, nem, por outro lado, que somente pela expansão da garantia legal seja possível aperfeiçoar a eficácia da proteção, a exemplo da contribuição importantíssima da negociação coletiva.

Quando se fala aqui em eficácia da proteção, o sentido adotado é aquele que traduz tanto a essência ou espírito da norma, quanto sua incidência no mundo concreto. Significa, então, que além de atuar no mundo concreto, a norma cumpriu a finalidade a que se destinava, pois foi socialmente observada, tendo solucionado o motivo que a gerou. Uma lei é eficaz quando cumprida a sua função social.

Sabe-se que boa parte da doutrina atual divide a efetividade em efetividade jurídica e efetividade social. A efetividade jurídica se verifica quando a norma tem nos limites objetivos todos os seus elementos: hipótese, disposição, sanção, podendo assim produzir efeitos desde logo no ordenamento, possibilitando a aplicação de sanção. Já a efetividade social de uma norma ocorre quando a mesma é respeitada por boa parte da sociedade, 
existindo assim um reconhecimento do Direito por parte desta e um amplo cumprimento dos preceitos normativos. É da utilização dos conceitos de efetividade jurídica e de efetividade social que se extrai o alicerce para a utilização do termo eficácia da proteção e para a medição desta mesma eficácia.

Assim, a eficácia é, nestes limites, a possibilidade de produção de efeitos e incidência e a concreta produção dos efeitos criados na realidade social.

Assim, a expansão da garantia legal em relação à proteção à maternidade, neste caso, resultou no aperfeiçoamento da eficácia da proteção, uma vez que, inserta em texto constitucional e aperfeiçoada na norma infraconstitucional (inclusive por meio da retificação das Convenções da OIT), atingiu sua finalidade social e produziu efeitos jurídicos no mundo concreto.

Ressalte-se que a Constituição, em relação à norma de proteção à maternidade, apesar de seu caráter programático, é auto-aplicável (vide jurisprudência no capítulo sobre a negociação coletiva).

Por fim, paira uma pergunta: que tipo de legislação protetiva à maternidade seria ideal para garantir ou indicar uma melhor garantia de eficácia da proteção à maternidade, na sociedade brasileira atual, considerando a importância dos direitos de conciliação entre trabalho e família e os desafios do mundo do trabalho?

Humildemente, pode-se responder que a legislação ideal é aquela possível. Assim, convém acreditar na evolução desta legislação, que por ora se mostra adequada interna e externamente, principalmente após a Lei 11.770/2008 e diante de todos os aspectos aqui analisados. Espera-se que a presente legislação evolua para o patamar constitucional, alterando inclusive a atual Consolidação das Leis do Trabalho, conduzindo o que hoje se considera facultativo para uma condição obrigatória a todos os empregadores.

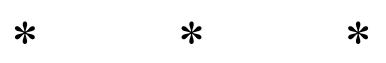

Rendo, aqui, uma homenagem à Constituição Federal, que no ano de minha seleção a este Programa de Pós-Graduação acabara de completar 20 anos. Orgulho-me da Constituição vigente: sem idealismos românticos, mas com convicção fundada nas transformações ocorridas nas últimas duas décadas e nas conquistas obtidas pelo povo brasileiro. Vale continuar lutando para que o Brasil continue evoluindo na direção de uma nação civilizada, desenvolvida e justa. 


\section{REFERÊNCIAS BIBLIOGRÁFICAS}

ABRAMO, Laís; ARMIJO, Marianela. Cambio tecnológico y el trabajo de las mujeres. Revista Estudos Feministas, vol. 5, n. 1, Rio de Janeiro, Instituto de Filosofia e Ciências Sociais, UFRJ, 1997, p. 31-67.

ABRAMO, Laís; RANGEL, Marta. Negociação coletiva e igualdade de gênero na América Latina. Brasília: OIT, 2005. (Cadernos GRPE n. 1)

ABRAMO, Laís; TODARO, Rosalba. Custos do trabalho de homens e mulheres na América Latina. In: COSTA, Albertina et al. (orgs.). Mercado de trabalho e gênero: comparações internacionais. Rio de Janeiro: FGV, 2008. p. 141-158.

ABRANTES, Abdias Duque de. Licença-maternidade: quatro ou seis meses? Jornal Trabalhista Consulex, v. 24, n. 1.153, p. 11, jan. 2007.

ALEXY, Robert. Teoria dos direitos fundamentais. 2. ed. Trad. Virgílio Afonso da Silva. São Paulo: Malheiros Editores, 2011.

AMARAL, Júlio Ricardo de Paula. Eficácia dos direitos fundamentais nas relações trabalhistas. São Paulo: LTr, 2007.

ASSUNÇÃO, Eraldo Dantas. A extensão da licença-maternidade à adotante em face do princípio da igualdade. Jus Navigandi, Teresina, ano 12, n. 1424, 26 maio 2007. Disponível em: http://jus.uol.com.br/revista/texto/9928.

BARROS, Alice Monteiro de. A mulher e o direito do trabalho. São Paulo: LTr, 1995.

BAUMAN, Zygmunt. Modernidade líquida. Rio de Janeiro: Jorge Zahar Ed., 2001.

BIAVASCHI, Magda B. Relações e condições de trabalho no Brasil contemporâneo: garantir direitos e promover a igualdade, in: KREIN, José Dari; SANTANA, Marco Aurélio; BIAVASCHI, Magda B. (Orgs.). Vinte anos da Constituição cidadã no Brasil. São Paulo: LTr, 2010. pp. 144-160.

BOBBIO, Norberto. A era dos direitos. Nova ed. Rio de Janeiro: Elsevier, 2004.

Direito e poder. São Paulo: Editora UNESP, 2008. 
CALIL, Léa Elisa Silingowschi. História do direito do trabalho da mulher: aspectos histórico-sociológicos do início da República ao final deste século. São Paulo: LTr, 2000.

CAMPOS JÚNIOR, Dioclécio. Liçença-maternidade sem preconceito. Jornal Trabalhista Consulex, v. 25, n. 1.234, p. 16, ago. 2008.

CANTELLI, Paula Oliveira. O trabalho feminino no divã: dominação e discriminação. São Paulo: LTr, 2007.

CARNEIRO, Ricardo. Desenvolvimento em crise: a economia brasileira no último quarto do século XX. São Paulo: Ed. Unesp; Unicamp.IE, 2002.

CARVALHO, Sandro Sacchet de; FIRPO, Sergio; GONZAGA, Gustavo. Os efeitos do aumento da licença-maternidade sobre o salário e o emprego da mulher no Brasil. Pesquisa e planejamento econômico, v. 36, n. 3, p. 489-523, dez. 2006.

CICCONETTI, Stefano Maria. Os direitos sociais na jurisprudência constitucional italiana, Direitos Fundamentais \& Justiça nº 2, jan/mar 2008, p. 93-104.

COMISSÃO aprova licença-maternidade obrigatória de 180 dias. Portal JusBrasil, 11.fev.2010. Disponível em: http://ibdfam.jusbrasil.com.br/noticias/2085306/comissaoaprova-licenca-maternidade-obrigatoria-de-180-dias. Acesso em 20/12/2011.

DÄUBLER, Wolfgang. Direito do trabalho e sociedade na Alemanha. São Paulo: LTr, 1997.

DELGADO, Maurício Godinho. Capitalismo, trabalho e emprego. São Paulo: LTr, 2006.

DEPARTAMENTO INTERSINDICAL DE ESTATÍSTICA E ESTUDOS SÓCIO-ECONÔMICOS. Negociação coletiva e eqüidade de gênero no Brasil: cláusulas relativas ao trabalho da mulher: 1996-2000. São Paulo: Dieese, 2003.

FIGUEIREDO, Antonio Borges de. Licença ou salário-maternidade de 180 dias: análise de duas propostas parlamentares. Revista de Previdência Social, v. 32, n. 328, p. 216-222, mar. 2008.

FONSECA, Verônica Cavalcante. Negociação coletiva na União Européia e no Mercosul. In: FREITAS JR, Antonio R.; SANTOS, Enoque R. dos (coords.); CAVALCANTE, Jouberto de Q. P. (orgs.). Direito coletivo do trabalho em debate. Rio de Janeiro: Ed. Lumen Juris, 2009.

FRANÇA, Dirce Barroso. Mãe social: o mito da reprodução do amor materno nas instituições de abrigo. In: ATEM, Lou Muniz (org.) Cuidados no início da vida: clínica, instituição, pesquisa e metapsicologia. São Paulo: Casa do Psicólogo, 2008.

FREDIANI, Yone. Licença-maternidade à mãe adotante: aspectos constitucionais. São Paulo: LTr, 2004.

FREITAS JR, Antonio Rodrigues de (org.). Direito do trabalho e direitos humanos. São Paulo: BH Editora e Distribuidora de Livros, 2006. 
FREITAS JR, Antonio Rodrigues de. O trabalho feminino no Brasil. Revista Jurídica do trabalho, Salvador/Lisboa, ano 1, n. 3, out./dez. 1988, pp. 211-237.

GALANTINO, Luisa. Diritto comunitario del lavoro. Torino: G. Giappichelli Editore, 2001.

GARCIA, Gustavo Filipe Barbosa. Prorrogação da licença-maternidade: lei $\mathrm{n}^{\mathrm{o}}$ 11.770/2008. Revista do Direito Trabalhista, v. 15, n. 2, p. 11-13, fev. 2009.

GUEDES, Márcia Novaes. Licença para as mães e direitos fundamentais das crianças. Revista Trabalhista: direito e processo, v. 2, n. 6, p. 148-154, abr./jun. 2003.

HARDY, Ellen E.; OSIS, Maria José M. D. Mulher, trabalho e amamentação: legislação e prática. Campinas: Editora da Unicamp, 1991.

HIRATA, Helena. Dicionário crítico do feminismo. São Paulo: Ed. Unesp, 2010.

HIRATA, Helena; KERGOAT, Danièle. Novas configurações da divisão sexual do trabalho. Cadernos de Pesquisa, Fundação Carlos Chagas, v. 37, n. 132, p. 595-609, setdez. 2007.

HOBSBAWM, Eric J. Mundos do trabalho. São Paulo: Paz e Terra, 2008.

HOFFMAN, Rodolfo; LEONE, Eugenia T. Participação da mulher no mercado de trabalho e desigualdade da renda domiciliar per capita no Brasil: 1981-2002, Nova Economia, Belo Horizonte, vol. 14, n. 2, maio/ago. 2004, pp. 35-58.

INSTITUTO BRASILEIRO DE GEOGRAFIA E ESTATÍSTICA. Indicadores sociodemográficos e de saúde no Brasil. Rio de Janeiro: IBGE, 2009.

JORDÃO, Claudia. Licença-maternidade só no papel. Isto é, v. 32, n. 2094, p. 54-56, 30 dez. 2009.

KLOSS, Larissa Renata. Prorrogação da licença-maternidade: favorável a quem?Revista do Tribunal Regional do Trabalho da $9^{a}$ Região, v. 34, n. 63, p. 189-203, jul./dez. 2009.

LENZA, Pedro. Direito constitucional esquematizado. 12. ed. rev., atual. e ampl. São Paulo: Saraiva, 2008.

MAGALHÃES, Maria Lúcia Cardoso de. A cidadania da mulher, uma questão de justiça. Revista do Tribunal Regional do Trabalho da $3^{a}$ Região, v. 35, n. 65, p. 23-46, jan./jun. 2002.

MARTINS, Sergio Pinto. Prorrogação da licença-maternidade por 60 dias. Repertório IOB de Jurisprudência: trabalhista e previdenciário, n. 3, fev. 2009, p. 97-94.

Convenções da OIT. São Paulo: Atlas, 2009.

Comentários às súmulas do TST. 8. ed. São Paulo: Editora Atlas, 2010.

MASSON, Celso. Por que as mães querem deixar o emprego para ficar com os filhos. Época, n. 474, 18 jun. 2007, p. 98-106. 
MONTANHANA, Beatriz. A. Constitucionalização dos direitos sociais: a afirmação da dignidade do trabalhador. In: FREITAS JR, Antonio Rodrigues de (org.). Direito do trabalho e direitos humanos. São Paulo: BH Editora e Distribuidora de Livros, 2006. pp. 63-109.

NAVES, Rubens. Licença-maternidade e cidadania. Jornal Trabalhista Consulex, v. 25, n. 1.239 , p. 16, set. 2008.

NEGRI, Antonio. A feminização do trabalho, Folha de São Paulo, São Paulo, 14.jun.1998, Seção Autores, p. 1.3.

NEIVERTH, Elisabeth Mônica Hasse Becker; MANDALOZZO, Silvana Souza Netto. A licença-maternidade e sua ampliação facultativa. Revista do Tribunal Regional do Trabalho da $9^{a}$ Região, v. 34, p. 63, p. 175-188, jul./dez. 2009.

NUNES, Rizzatto. Manual de filosofia do direito. 2. ed. São Paulo: Saraiva, 2009.

ORGANIZAÇÃO INTERNACIONAL DO TRABALHO. Trabalho e familia: rumo a novas formas de conciliação com co-responsabilidade social. (Em associação com o Programa das Nações Unidas pelo Desenvolvimento - PNUD). Brasília: OIT, 2009.

ORGANIZAÇÃO INTERNACIONAL DO TRABALHO. Negociação de cláusulas de trabalho relativas à igualdade de gênero e raça: 2007-2009. Brasília: OIT; São Paulo: Dieese, 2011.

ORGANIZACIÓN INTERNACIONAL DEL TRABAJO. La maternidad en el trabajo: examen de la legislación nacional. 2. ed. Ginebra: OIT, 2010.

PASTORE, José. A proteção da maternidade. Revista do Direito Trabalhista, v. 13, n. 7, p. 3, jul. 2007.

PASTORE, José. Licença-maternidade de 180 dias. Texto apresentado na Audiência Pública do Senado Federal, Brasília, em 21 de março de 2007. Disponível em: http://www.josepastore.com.br/artigos/rt/rt_111.htm. Acesso em 20/12/2011.

PESSOA, Flávia Moreira Guimarães. Curso de direito constitucional do trabalho. Bahia: Jus Podivm, 2009.

POCHMANN, Marcio. A década dos mitos. São Paulo: Contexto, 2001.

PROGRAMA DAS NAÇÕES UNIDAS PARA O DESENVOLVIMENTO. Relatório de Desenvolvimento Humano 2010. New York: PNUD, 2010.

PRONI, Marcelo W.; ROCHA, Thaíssa Tamarindo da. A OIT e a promoção do trabalho decente no Brasil, Revista da ABET, Associação Brasileira de Estudos do Trabalho, São Paulo, v. IX, n. 1, jan./jun. 2010. pp. 11-33.

RABELO, Carina. Licença-maternidade de seis meses: projeto tenta ampliar o benefício, mas as mães temem o desemprego. Isto é, n. 1.953, p. 68-69, 4 abr. 2007.

RAWLS, John. Uma teoria da justiça. 3. ed. Trad. Jussara Simões. São Paulo: Martins Fontes, 2008 [1971]. 
REALE, Miguel. Filosofia do direito. 19. ed. São Paulo: Saraiva, 1999 [1953].

RIOS-NETO, Eduardo L. G. BATISTA, Dulce B. D. Alvarenga. Segregação ocupacional entre solteiras e casadas: o possível impacto da licença-maternidade. Revista do XI Encontro Nacional de Estudos Populacionais da ABEP. MG: 1998.P. 2664-2686.

ROCHA, Thaíssa Tamarindo da. Promoção do trabalho decente no limiar do século XXI: velhos obstáculos, novos paradigmas. Campinas: Unicamp.IE, 2007. (Monografia, Especialização em Economia do Trabalho e Sindicalismo).

ROMANO, Sylvia. A ampliação da licença-maternidade e o risco de discriminação contra a mulher. Jornal Trabalhista Consulex, v. 24, n. 1.194, p. 11, out. 2007.

RUZZARIN, Jean P. Servidoras licença-maternidade de seis meses. Correio Braziliense, Brasília, n. 16570, 29 set. 2008. Caderno Direito e Justiça, p. 2.

SALOMONE, Roberto. Perfil: Melanie Healey, Você S/A, ed. 13, Especial Mulheres 2, junho de 2011, pp. 34-39.

SANTOS, Enoque Ribeiro dos. A negociação coletiva de trabalho como instrumento de pacificação social. In: THOMÉ, Candy Florencio; SCHWARTZ, Rodrigo Garcia (orgs.) Direito coletivo do trabalho: curso de revisão e atualização. Rio de Janeiro: Elsevier, 2010.

SILVA, Alessandro da; KROST, Oscar. Comentários sobre a licença-maternidade e as inovações da Lei n. 11.770/2008. In: O trabalho: doutrina em fascículos mensais, n. 143, p. 4844-4850, jan. 2009.

SILVA, Homero Batista da. Direito de direito do trabalho aplicado. Rio de Janeiro: Elsevier, 2009. (vol. 3: Segurança e medicina do trabalho, trabalho da mulher e do menor).

SOUTO MAIOR, Jorge Luiz. Relação de emprego e direito do trabalho. São Paulo: LTr, 2008.

SUSSEKIND, Arnaldo. As convenções da OIT sobre prestação à maternidade e a legislação brasileira. Jornal Trabalhista Consulex, v. 17, n. 821, p. 8, 17 jul. 2000.

THOME, Candy Florencio. Direitos de conciliação entre trabalho e família: licençamaternidade e licença-paternidade. São Paulo: LTr, 2009.

UNITED NATIONS. International Women's Day: looking back. Women Watch; United Nations Department of Public Information, January 1997. Available in: < http://www.un.org/womenwatch/feature/iwd/history.html $>$ Consulted on January 2012. 


\section{ANEXO I}

Convenção e Legislação 


\section{Convenção 183 da OIT:}

The General Conference of the International Labour Organization,

Having been convened at Geneva by the Governing Body of the International Labour Office, and having met in its 88th Session on 30 May 2000, and

Noting the need to revise the Maternity Protection Convention (Revised), 1952, and the Maternity Protection Recommendation, 1952, in order to further promote equality of all women in the workforce and the health and safety of the mother and child, and in order to recognize the diversity in economic and social development of Members, as well as the diversity of enterprises, and the development of the protection of maternity in national law and practice, and

Noting the provisions of the Universal Declaration of Human Rights (1948), the United Nations Convention on the Elimination of All Forms of Discrimination Against Women (1979), the United Nations Convention on the Rights of the Child (1989), the Beijing Declaration and Platform for Action (1995), the International Labour Organization's Declaration on Equality of Opportunity and Treatment for Women Workers (1975), the International Labour Organization's Declaration on Fundamental Principles and Rights at Work and its Follow-up (1998), as well as the international labour Conventions and Recommendations aimed at ensuring equality of opportunity and treatment for men and women workers, in particular the Convention concerning Workers with Family Responsibilities, 1981, and

Taking into account the circumstances of women workers and the need to provide protection for pregnancy, which are the shared responsibility of government and society, and

Having decided upon the adoption of certain proposals with regard to the revision of the Maternity Protection Convention (Revised), 1952, and Recommendation, 1952, which is the fourth item on the agenda of the session, and

Having determined that these proposals shall take the form of an international Convention;

adopts this fifteenth day of June of the year two thousand the following Convention, which may be cited as the Maternity Protection Convention, 2000.

SCOPE

Article 1

For the purposes of this Convention, the term woman applies to any female person without discrimination whatsoever and the term child applies to any child without discrimination whatsoever.

Article 2

1. This Convention applies to all employed women, including those in atypical forms of dependent work.

2. However, each Member which ratifies this Convention may, after consulting the representative organizations of employers and workers concerned, exclude wholly or partly from the scope of the Convention limited categories of workers when its application to them would raise special problems of a substantial nature.

3. Each Member which avails itself of the possibility afforded in the preceding paragraph shall, in its first report on the application of the Convention under article 22 of the Constitution of the International Labour Organization, list the categories of workers thus excluded and the reasons for their exclusion. In its subsequent reports, the Member shall describe the measures taken with a view to progressively extending the provisions of the Convention to these categories. 


\section{HEALTH PROTECTION}

Article 3

Each Member shall, after consulting the representative organizations of employers and workers, adopt appropriate measures to ensure that pregnant or breastfeeding women are not obliged to perform work which has been determined by the competent authority to be prejudicial to the health of the mother or the child, or where an assessment has established a significant risk to the mother's health or that of her child.

\section{MATERNITY LEAVE}

Article 4

1. On production of a medical certificate or other appropriate certification, as determined by national law and practice, stating the presumed date of childbirth, a woman to whom this Convention applies shall be entitled to a period of maternity leave of not less than 14 weeks.

2. The length of the period of leave referred to above shall be specified by each Member in a declaration accompanying its ratification of this Convention.

3. Each Member may subsequently deposit with the Director-General of the International Labour Office a further declaration extending the period of maternity leave.

4. With due regard to the protection of the health of the mother and that of the child, maternity leave shall include a period of six weeks' compulsory leave after childbirth, unless otherwise agreed at the national level by the government and the representative organizations of employers and workers.

5. The prenatal portion of maternity leave shall be extended by any period elapsing between the presumed date of childbirth and the actual date of childbirth, without reduction in any compulsory portion of postnatal leave.

\section{LEAVE IN CASE OF ILLNESS OR COMPLICATIONS}

Article 5

On production of a medical certificate, leave shall be provided before or after the maternity leave period in the case of illness, complications or risk of complications arising out of pregnancy or childbirth. The nature and the maximum duration of such leave may be specified in accordance with national law and practice.

\section{BENEFITS}

Article 6

1. Cash benefits shall be provided, in accordance with national laws and regulations, or in any other manner consistent with national practice, to women who are absent from work on leave referred to in Articles 4 or 5 .

2. Cash benefits shall be at a level which ensures that the woman can maintain herself and her child in proper conditions of health and with a suitable standard of living.

3. Where, under national law or practice, cash benefits paid with respect to leave referred to in Article 4 are based on previous earnings, the amount of such benefits shall not be less than two-thirds of the woman's previous earnings or of such of those earnings as are taken into account for the purpose of computing benefits. 
4. Where, under national law or practice, other methods are used to determine the cash benefits paid with respect to leave referred to in Article 4, the amount of such benefits shall be comparable to the amount resulting on average from the application of the preceding paragraph.

5. Each Member shall ensure that the conditions to qualify for cash benefits can be satisfied by a large majority of the women to whom this Convention applies.

6. Where a woman does not meet the conditions to qualify for cash benefits under national laws and regulations or in any other manner consistent with national practice, she shall be entitled to adequate benefits out of social assistance funds, subject to the means test required for such assistance.

7. Medical benefits shall be provided for the woman and her child in accordance with national laws and regulations or in any other manner consistent with national practice. Medical benefits shall include prenatal, childbirth and postnatal care, as well as hospitalization care when necessary.

8. In order to protect the situation of women in the labour market, benefits in respect of the leave referred to in Articles 4 and 5 shall be provided through compulsory social insurance or public funds, or in a manner determined by national law and practice. An employer shall not be individually liable for the direct cost of any such monetary benefit to a woman employed by him or her without that employer's specific agreement except where:

(a) such is provided for in national law or practice in a member State prior to the date of adoption of this Convention by the International Labour Conference; or

(b) it is subsequently agreed at the national level by the government and the representative organizations of employers and workers.

\section{Article 7}

1. A Member whose economy and social security system are insufficiently developed shall be deemed to be in compliance with Article 6, paragraphs 3 and 4, if cash benefits are provided at a rate no lower than a rate payable for sickness or temporary disability in accordance with national laws and regulations.

2. A Member which avails itself of the possibility afforded in the preceding paragraph shall, in its first report on the application of this Convention under article 22 of the Constitution of the International Labour Organization, explain the reasons therefor and indicate the rate at which cash benefits are provided. In its subsequent reports, the Member shall describe the measures taken with a view to progressively raising the rate of benefits.

\section{EMPLOYMENT PROTECTION AND NON-DISCRIMINATION}

Article 8

1. It shall be unlawful for an employer to terminate the employment of a woman during her pregnancy or absence on leave referred to in Articles 4 or 5 or during a period following her return to work to be prescribed by national laws or regulations, except on grounds unrelated to the pregnancy or birth of the child and its consequences or nursing. The burden of proving that the reasons for dismissal are unrelated to pregnancy or childbirth and its consequences or nursing shall rest on the employer.

2. A woman is guaranteed the right to return to the same position or an equivalent position paid at the same rate at the end of her maternity leave.

Article 9

1. Each Member shall adopt appropriate measures to ensure that maternity does not constitute a source of discrimination in employment, including - notwithstanding Article 2, paragraph 1 - access to employment. 
2. Measures referred to in the preceding paragraph shall include a prohibition from requiring a test for pregnancy or a certificate of such a test when a woman is applying for employment, except where required by national laws or regulations in respect of work that is:

(a) prohibited or restricted for pregnant or nursing women under national laws or regulations; or

(b) where there is a recognized or significant risk to the health of the woman and child.

\section{BREASTFEEDING MOTHERS}

Article 10

1. A woman shall be provided with the right to one or more daily breaks or a daily reduction of hours of work to breastfeed her child.

2. The period during which nursing breaks or the reduction of daily hours of work are allowed, their number, the duration of nursing breaks and the procedures for the reduction of daily hours of work shall be determined by national law and practice. These breaks or the reduction of daily hours of work shall be counted as working time and remunerated accordingly.

\section{PERIODIC REVIEW}

Article 11

Each Member shall examine periodically, in consultation with the representative organizations of employers and workers, the appropriateness of extending the period of leave referred to in Article 4 or of increasing the amount or the rate of the cash benefits referred to in Article 6.

\section{IMPLEMENTATION}

Article 12

This Convention shall be implemented by means of laws or regulations, except in so far as effect is given to it by other means such as collective agreements, arbitration awards, court decisions, or in any other manner consistent with national practice.

\section{FINAL PROVISIONS}

Article 13

This Convention revises the Maternity Protection Convention (Revised), 1952.

Article 14

The formal ratifications of this Convention shall be communicated to the Director-General of the International Labour Office for registration.

Article 15

1. This Convention shall be binding only upon those Members of the International Labour Organization whose ratifications have been registered with the Director-General of the International Labour Office.

2. It shall come into force 12 months after the date on which the ratifications of two Members have been registered with the Director-General. 3. Thereafter, this Convention shall come into force for any Member 12 months after the date on which its ratification has been registered. 
Article 16

1. A Member which has ratified this Convention may denounce it after the expiration of ten years from the date on which the Convention first comes into force, by an act communicated to the Director-General of the International Labour Office for registration. Such denunciation shall not take effect until one year after the date on which it is registered.

2. Each Member which has ratified this Convention and which does not, within the year following the expiration of the period of ten years mentioned in the preceding paragraph, exercise the right of denunciation provided for in this Article, will be bound for another period of ten years and, thereafter, may denounce this Convention at the expiration of each period of ten years under the terms provided for in this Article.

Article 17

1. The Director-General of the International Labour Office shall notify all Members of the International Labour Organization of the registration of all ratifications and acts of denunciation communicated by the Members of the Organization.

2. When notifying the Members of the Organization of the registration of the second ratification, the Director-General shall draw the attention of the Members of the Organization to the date upon which the Convention shall come into force.

Article 18

The Director-General of the International Labour Office shall communicate to the Secretary-General of the United Nations, for registration in accordance with article 102 of the Charter of the United Nations, full particulars of all ratifications and acts of denunciation registered by the Director-General in accordance with the provisions of the preceding Articles.

Article 19

At such times as it may consider necessary, the Governing Body of the International Labour Office shall present to the General Conference a report on the working of this Convention and shall examine the desirability of placing on the agenda of the Conference the question of its revision in whole or in part.

Article 20

1. Should the Conference adopt a new Convention revising this Convention in whole or in part, then, unless the new Convention otherwise provides:

(a) the ratification by a Member of the new revising Convention shall ipso jure involve the immediate denunciation of this Convention, notwithstanding the provisions of Article 16 above, if and when the new revising Convention shall have come into force;

(b) as from the date when the new revising Convention comes into force, this Convention shall cease to be open to ratification by the Members.

2. This Convention shall in any case remain in force in its actual form and content for those Members which have ratified it but have not ratified the revising Convention.

Article 21

The English and French versions of the text of this Convention are equally authoritative. 


\title{
Lei no 11.770 , de 9 de setembro de 2008
}

DOU de 10.9.2008

Cria o Programa Empresa Cidadã, destinado à prorrogação da licença-maternidade mediante concessão de incentivo fiscal, e altera a Lei no 8.212, de 24 de julho de 1991.

O PRESIDENTE DA REPÚBLICA Faço saber que o Congresso Nacional decreta e eu sanciono a seguinte Lei:

Art. $1^{0}$ É instituído o Programa Empresa Cidadã, destinado a prorrogar por 60 (sessenta) dias a duração da licençamaternidade prevista no inciso XVIII do caput do art. $7^{\circ}$ da Constituição Federal.

$\S 1^{\circ}$ A prorrogação será garantida à empregada da pessoa jurídica que aderir ao Programa, desde que a empregada a requeira até o final do primeiro mês após o parto, e concedida imediatamente após a fruição da licença-maternidade de que trata o inciso XVIII do caput do art. $7^{\circ}$ da Constituição Federal.

$\S 2^{\circ}$ A prorrogação será garantida, na mesma proporção, também à empregada que adotar ou obtiver guarda judicial para fins de adoção de criança.

Art. $2^{0}$ É a administração pública, direta, indireta e fundacional, autorizada a instituir programa que garanta prorrogação da licença-maternidade para suas servidoras, nos termos do que prevê o art. $1^{\circ}$ desta Lei.

Art. $3^{0}$ Durante o período de prorrogação da licença-maternidade, a empregada terá direito à sua remuneração integral, nos mesmos moldes devidos no período de percepção do salário-maternidade pago pelo regime geral de previdência social.

Art. $4^{\mathbf{0}}$ No período de prorrogação da licença-maternidade de que trata esta Lei, a empregada não poderá exercer qualquer atividade remunerada e a criança não poderá ser mantida em creche ou organização similar.

Parágrafo único. Em caso de descumprimento do disposto no caput deste artigo, a empregada perderá o direito à prorrogação.

Art. $5^{\circ}$ A pessoa jurídica tributada com base no lucro real poderá deduzir do imposto devido, em cada período de apuração, o total da remuneração integral da empregada pago nos 60 (sessenta) dias de prorrogação de sua licençamaternidade, vedada a dedução como despesa operacional.

Parágrafo único. (VETADO)

Art. $6^{0}$ ( VETADO)

Art. $7^{\circ}$ O Poder Executivo, com vistas no cumprimento do disposto no inciso II do caput do art. $5^{\circ}$ e nos arts. 12 e 14 da Lei Complementar $n^{\circ} 101$, de 4 de maio de 2000, estimará o montante da renúncia fiscal decorrente do disposto nesta Lei e o incluirá no demonstrativo a que se refere o $\S 6^{\circ}$ do art. 165 da Constituição Federal, que acompanhará o projeto de lei orçamentária cuja apresentação se der após decorridos 60 (sessenta) dias da publicação desta Lei.

Art. $\mathbf{8}^{\mathbf{0}}$ Esta Lei entra em vigor na data de sua publicação, produzindo efeitos a partir do primeiro dia do exercício subseqüente àquele em que for implementado o disposto no seu art. $7^{\circ}$.

Brasília, 9 de setembro de $2008 ; 187^{\circ}$ da Independência e $120^{\circ}$ da República.

\author{
LUIZ INÁCIO LULA DA SILVA \\ Guido Mantega \\ Carlos Lupi \\ José Pimentel
}


ANEXO II

Quadros e Tabelas 
Tabela A-1

Duração da licença-maternidade, em \%

\begin{tabular}{lcccc}
\hline \multicolumn{1}{c}{ Região } & $\begin{array}{c}\text { Menos de } \\
12 \text { semanas }\end{array}$ & $\begin{array}{c}12 \text { a 13 } \\
\text { semanas }\end{array}$ & $\begin{array}{c}14 \text { a 17 } \\
\text { semanas }\end{array}$ & $\begin{array}{c}18 \text { ou mais } \\
\text { semanas }\end{array}$ \\
\hline Economias Desenvolvidas e União Europeia & 0 & 8 & 46 & 46 \\
Europa Central e CEI & 0 & 0 & 7 & 93 \\
América Latina e Caribe & 6 & 72 & 13 & 9 \\
Ásia e Pacífico & 17 & 65 & 17 & 0 \\
África & 18 & 34 & 48 & 0 \\
Oriente Médio & 82 & 0 & 18 & 0 \\
\hline Todas as Regiões & 14 & 35 & 31 & 20 \\
\hline
\end{tabular}

Fonte: OIT. La maternidade en el trabajo, 2010.

Tabela A-2

Fontes de financiamento da proteção à maternidade, em \%

\begin{tabular}{lcccc}
\hline \multicolumn{1}{c}{ Região } & $\begin{array}{c}\text { Previdência } \\
\text { Social }\end{array}$ & Empregador & $\begin{array}{c}\text { Sistema } \\
\text { Misto }\end{array}$ & $\begin{array}{c}\text { Sem } \\
\text { Financiamento }\end{array}$ \\
\hline Economias Desenvolvidas e União Europeia & 84 & 3 & 8 & 5 \\
Europa Central e CEI & 93 & 7 & 0 & 0 \\
América Latina e Caribe & 59 & 6 & 34 & 0 \\
Ásia e Pacífico & 30 & 52 & 13 & 4 \\
África & 34 & 38 & 24 & 4 \\
Oriente Médio & 18 & 82 & 0 & 0 \\
\hline Todas as Regiões & 53 & 26 & 17 & 3 \\
\hline
\end{tabular}

Fonte: OIT. La maternidade en el trabajo, 2010. 


\section{Quadro A-1}

Disposições legais para a proteção à maternidade em países desenvolvidos ou da União Europeia

\begin{tabular}{|c|c|c|}
\hline País & Duração & \% do Salário \\
\hline Alemanha & 14 semanas & $100 \%$ \\
\hline Austrália & 52 semanas & sem remuneração \\
\hline Áustria & 16 semanas & $100 \%$ \\
\hline Bélgica & 15 semanas & $82 \%$ para 30 dias, $75 \%$ depois disso \\
\hline Bulgária & 227 dias & $90 \%$ \\
\hline Canadá & 17 semanas & $55 \%$ \\
\hline Coreia do Sul & 90 dias & $100 \%$ \\
\hline Dinamarca & 18 semanas & $100 \%$ \\
\hline Eslováquia & 28 semanas & $55 \%$ \\
\hline Espanha & 16 semanas & $100 \%$ \\
\hline Estados Unidos & 12 semanas & sem remuneração \\
\hline Estônia & 140 dias & $100 \%$ \\
\hline França & 16 semanas & $100 \%$ \\
\hline Grécia & 119 dias & $100 \%$ \\
\hline Holanda & 16 semanas & $100 \%$ \\
\hline Hungria & 24 semanas & $70 \%$ \\
\hline Irlanda & 42 semanas & $\begin{array}{c}80 \% \text { até } 26 \text { semanas; sem remuneração } \\
\text { a partir da } 27 \text { a semana }\end{array}$ \\
\hline Israel & 12 semanas & $100 \%$ \\
\hline Itália & 5 meses & $80 \%$ \\
\hline Japão & 14 semanas & $60 \%$ \\
\hline Lituania & 126 dias & $100 \%$ \\
\hline Luxemburgo & 16 semanas & $100 \%$ \\
\hline Noruega & 36 semanas & $100 \%$ \\
\hline Polônia & 20 semanas & $100 \%$ \\
\hline Portugal & 120 dias $(150)$ & $100 \%(80 \%)$ \\
\hline Reino Unido & 52 semanas & $\begin{array}{l}\text { 90\% ou valor fixo até } 39 \text { semanas; sem } \\
\text { remuneração a partir da 40a semana }\end{array}$ \\
\hline República Checa & 28 semanas & $69 \%$ \\
\hline Romênia & 126 dias & $85 \%$ \\
\hline Suécia & 14 semanas & $80 \%$ \\
\hline Suíça & 14 semanas & $80 \%$ \\
\hline
\end{tabular}

Fonte: OIT. La maternidade en el trabajo, 2010. 
Quadro A-2

Disposições legais para a proteção à maternidade em países em desenvolvimento

\begin{tabular}{|c|c|c|}
\hline País & Duração & \% do Salário \\
\hline África do Sul & 4 meses & Até $60 \%$ \\
\hline Albania & 365 dias & $80 \%$ até 150 dias; $50 \%$ depois \\
\hline Arábia Saudita & 10 semanas & $50 \%$ ou $100 \%$ (tempo de emprego) \\
\hline Argentina & 90 dias & $100 \%$ \\
\hline Bangladesh & 16 semanas & $100 \%$ \\
\hline Bolívia & 60 dias & $100 \%$ do sal. mín. $+70 \%$ acima do sm \\
\hline Brasil & 120 dias & $100 \%$ \\
\hline Chile & 18 semanas & $100 \%$ \\
\hline China & 90 dias & $100 \%$ \\
\hline Colômbia & 12 semanas & $100 \%$ \\
\hline Costa Rica & 4 meses & $100 \%$ \\
\hline Croácia & $\begin{array}{l}45 \text { dias antes do parto; } \\
\text { até } 1 \text { ano depois }\end{array}$ & $\begin{array}{c}100 \% \text { até } 6 \text { meses depois do parto; } \\
\text { valor fixo depois }\end{array}$ \\
\hline Cuba & 18 semanas & $100 \%$ \\
\hline Egito & 3 meses & $100 \%$ \\
\hline Equador & 12 semanas & $100 \%$ \\
\hline El Salvador & 12 semanas & $75 \%$ \\
\hline Filipinas & 60 dias & $100 \%$ \\
\hline Honduras & 10 semanas & $100 \%$ para 84 dias \\
\hline Índia & 12 semanas & $100 \%$ \\
\hline Indonésia & 3 meses & $100 \%$ \\
\hline Malásia & 60 dias & $100 \%$ \\
\hline México & 12 semanas & $100 \%$ \\
\hline Moçambique & 60 dias & $100 \%$ \\
\hline Nicarágua & 12 semanas & $100 \%$ \\
\hline Nigéria & 12 semanas & $50 \%$ \\
\hline Panamá & 14 semanas & $100 \%$ \\
\hline Paraguai & 12 semanas & $50 \%$ para 9 semanas \\
\hline Peru & 90 dias & $100 \%$ \\
\hline República Dominicana & 12 semanas & $100 \%$ \\
\hline Rússia & 140 dias & $100 \%$ \\
\hline Sérvia & 365 dias (2 filhos) & $100 \%$ \\
\hline Singapura & 16 semanas & $100 \%$ (até o 2o filho) \\
\hline Turquia & 16 semanas & $66,7 \%$ \\
\hline Ucrânia & 126 dias & $100 \%$ \\
\hline Uruguai & 12 semanas & $100 \%$ \\
\hline Venezuela & 18 semanas & $100 \%$ \\
\hline Vietnã & 4 a 6 meses & $100 \%$ \\
\hline
\end{tabular}

Fonte: OIT. La maternidade en el trabajo, 2010. 
QUADRO A-3

AMÉRICA LATINA E CARIBE: LEGISLAÇÃO NACIONAL SOBRE PROTEÇäO À MATERNIDAdE

\begin{tabular}{|c|c|c|c|}
\hline Pais & $\begin{array}{l}\text { Licença maternidade } \\
\text { (semanas) }\end{array}$ & $\begin{array}{l}\text { Beneficio durante a } \\
\text { licença (\% do salário) }\end{array}$ & Fonte do beneficio \\
\hline Antigua e Barbuda & 6 & $40 \% / 60 \% / 100 \%$ & $\begin{array}{l}\text { Empregador: } 40 \% \text { durante } 6 \text { semanas; e Previdência } \\
\text { Social: } 60 \% \text { durante } 13 \text { semanas, para trabalhadoras com } \\
\text { contribuiçōes }\end{array}$ \\
\hline Argentina & 13 (90 dias) & $100 \%$ & Previdência Social \\
\hline Bahamas & 12 & $100 \%$ & $\begin{array}{l}\text { Previdência Social e empregador ( } 33,3 \% \text { do salário; totalidade } \\
\text { se a trabalhadora não tem contribuiçâo em dia) }\end{array}$ \\
\hline Barbados & 12 & $100 \%$ & Previdência Social \\
\hline Belize & 14 & $80 \%$ & Previdência Social \\
\hline Bolivia & 13 (90 dias) & $100 \%$ & Previdência Social e empregador (10\%) \\
\hline Brasil & $\begin{array}{l}17 \text { (120 dias, } \\
\text { prorrogável por } 60 \text { dias) }\end{array}$ & $100 \%$ & Previdência Social \\
\hline Chile & 18 & $100 \%$ & Previdência Social \\
\hline Colômbia & 12 & $100 \%$ & Previdência Social \\
\hline Costa Rica & 16 (4 meses) & $100 \%$ & $\begin{array}{l}\text { Previdência Social e empregador ( } 50 \% \text {; totalidade se a } \\
\text { trabalhadora não tem contribuição em dia) }\end{array}$ \\
\hline Cuba & 18 & $100 \%$ & Previdência Social \\
\hline Dominica & 12 & $60 \%$ & Previdência Social e empregador \\
\hline Equador & 12 & $100 \%$ & $\begin{array}{l}\text { Previdência Social; empregador se a trabalhadora não tem } \\
\text { contribuiçôes por dia }\end{array}$ \\
\hline El Salvador & 12 & $75 \%$ & Empregador \\
\hline Granada & 12 ( 3 meses) & $65 \%$ & Previdência Social \\
\hline Guatemala & 12 (84 dias) & $100 \%$ & $\begin{array}{l}\text { Previdência Social e empregador ( } 1 / 3 \text {; totalidade se a } \\
\text { trabalhadora não tem contribuiçôes em dia) }\end{array}$ \\
\hline Guiana & 13 & $70 \%$ & Previdência Social \\
\hline Haiti & 12 & $\begin{array}{l}100 \% \text { (durante } 6 \\
\text { semanas) }\end{array}$ & Previdência Social \\
\hline Honduras & 10 & $\begin{array}{l}100 \% \text { (média de } \\
6 \text { meses) }\end{array}$ & $\begin{array}{l}\text { Previdência Social e empregador (diferença subsídio-salário; } \\
\text { totalidade se a trabalhadora não tem contribuiçōes em dia) }\end{array}$ \\
\hline Jamaica & 12 & $\begin{array}{l}100 \% \text { (durante } 8 \\
\text { semanas) }\end{array}$ & $\begin{array}{l}\text { Empregador; Previdência Social, em caso de trabalhadoras } \\
\text { domésticas (salário mínimo) }\end{array}$ \\
\hline México & 12 & $100 \%$ & $\begin{array}{l}\text { Previdência Social e empregador ( } 1 / 3 \text {; totalidade se a } \\
\text { trabalhadora não tem contribuiçôes em dia) }\end{array}$ \\
\hline Nicarágua & 12 & $100 \%$ & Previdência Social \\
\hline Panamá & 14 & $100 \%$ & $\begin{array}{l}\text { Previdência Social e empregador (diferença subsídio-salário; } \\
\text { totalidade se a trabalhadora não tem contribuiçōes em dia) }\end{array}$ \\
\hline Paraguai & 12 & $\begin{array}{l}50 \% \text { (beneficios } \\
\text { suficientes) }\end{array}$ & $\begin{array}{l}\text { Previdência Social; empregador se a trabalhadora não tem } \\
\text { contribuições por dia }\end{array}$ \\
\hline Peru & 13 & $100 \%$ & Previdência Social \\
\hline República Dominicana & 12 & $100 \%$ & Previdência Social e empregador $50 \%$ \\
\hline Santa Lucia & 13 & $65 \%$ & Previdência Social e empregador \\
\hline Trinidad e Tobago & 13 & $100 \%$ & $\begin{array}{l}\text { Empregador: } 1 \text { mês } 100 \%, 2 \text { meses } 50 \% \\
\text { Previdência Social: } \% \text { a depender do nivel salarial }\end{array}$ \\
\hline Uruguai & 12 & $100 \%$ & Previdência Social \\
\hline Venezuela & 18 & $100 \%$ & Previdência Social \\
\hline
\end{tabular}

Fonte: OIT. Trabalho e familia, 2009, p. 84. 